Jônatas Bussador do Amaral

\title{
CÉLULAS MCF-7 COMO MODELO \\ 3D NO ESTUDO DE CÂNCER DE \\ MAMA HUMANO.
}

\begin{abstract}
Tese apresentada ao Programa de Pós-Graduação em Biologia Celular e Tecidual do Instituto de Ciências Biomédicas da Universidade de São Paulo, para obtenção do Título de
\end{abstract} Doutor em Ciências

São Paulo 2010 


\section{Jônatas Bussador do Amaral}

\section{CÉLULAS MCF-7 COMO MODELO 3D NO ESTUDO DE CÂNCER DE MAMA HUMANO}

Tese apresentada ao Programa de PósGraduação em Biologia Celular e Tecidual do Instituto de Ciências Biomédicas da Universidade de São Paulo, para obtenção do Título de Doutor em Ciências.

Área de concentração: Biologia Celular e Tecidual

Orientadora: $\operatorname{Prof}^{\mathrm{a}} \operatorname{Dr}^{\mathrm{a}}$ Gláucia Maria Machado-Santelli 
DADOS DE CATALOGAÇÃO NA PUBLICAÇÃO (CIP)

Serviço de Biblioteca e Informação Biomédica do

Instituto de Ciências Biomédicas da Universidade de São Paulo

reprodução não autorizada pelo autor

Amaral, Jônatas Bussador do.

Células MCF-7 como modelo 3D no estudo de câncer de mama humano / Jônatas Bussador do Amaral. -- São Paulo, 2010.

Orientador: Gláucia Maria Machado Santelli.

Tese (Doutorado) - Universidade de São Paulo. Instituto de Ciências Biomédicas. Departamento de Biologia Celular e do Desenvolvimento. Área de concentração: Biologia Celular e Tecidual. Linha de pesquisa: Biologia da célula tumoral

Versão do título para o inglês: MCF-7 cells as a 3D model in the study of human breast cancer.

Descritores: 1. Culturas de células em três-dimensões 2. Mama 3. Neoplasias 4. Apoptose 5.Citoesqueleto 6. Esferóides multicelulares I. Santelli, Gláucia Maria Machado II. Universidade de São Paulo. Instituto de Ciências Biomédicas. Programa de PósGraduação em Biologia Celular e Tecidual III. Título. 
Candidato(a): Jônatas Bussador do Amaral.

Título da Tese: $\quad$ Células MCF-7 como modelo 3D no estudo de câncer de mama humano.

Orientador(a): $\quad$ Gláucia Maria Machado Santelli.

A Comissão Julgadora dos trabalhos de Defesa da Tese de Doutorado, em sessão pública realizada a .I. I... considerou
( ) Aprovado(a)
( ) Reprovado(a)

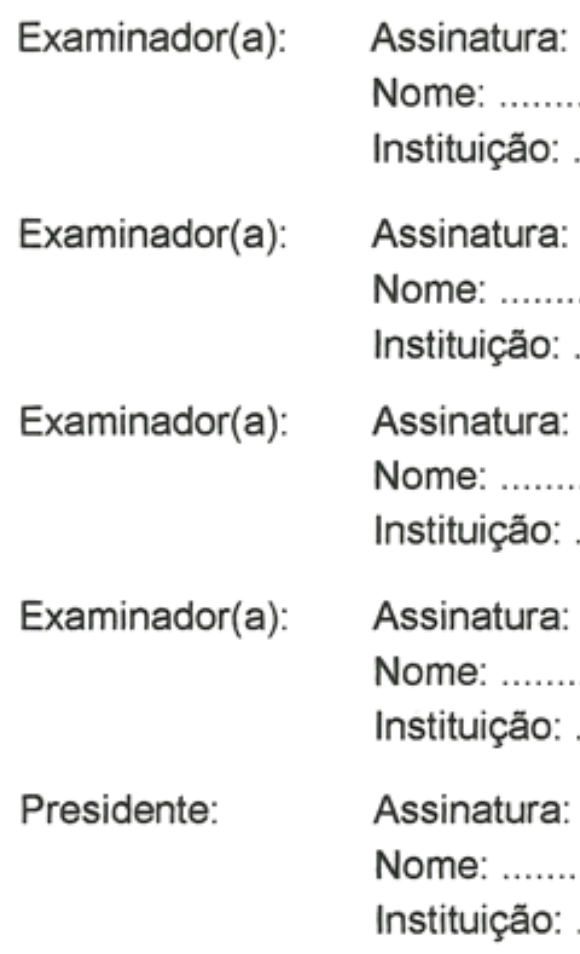




\section{CERTIFICADO DE ISENÇÃO}

Certificamos que o Protocolo CEP-ICB N ${ }^{\circ} 314 / 09$, referente ao projeto intitulado: "Morfologia nuclear e organização citoesqueleto em cultura 3-D de células tumorais " sob a responsabilidade de Jônatas Bussador do Amaral, foi analisado na presente data pela CEEA - COMISSÃO DE ÉtICA EM EXPERIMENTAÇÃo ANIMAL e pela CEPSH - COMISSÃo DE Ética EM PESQUisa COM SEREs humanos, tendo sido deliberado que o referido projeto não envolve manipulação animal ou humana que justifique uma aprovação quanto aos princípios éticos exigidos por ambas as Comissões.

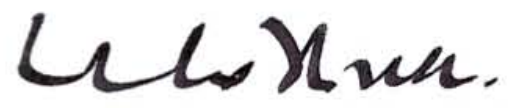

PROF. DR. WOTHAN TAVARES DE LIMA Coordenador da CEEA - ICB/USP
São Paulo, 16 de junho de 2009.

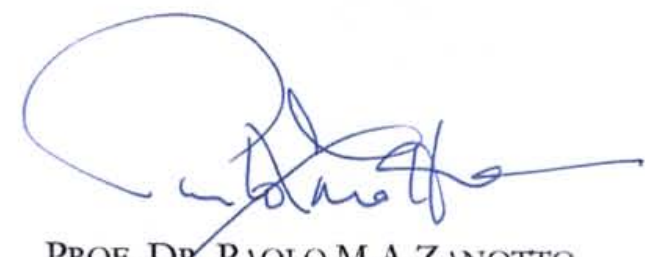

PROF. DR. PAOLO M.A ZANOTTO Vice-Cooraenador da CEPsh - ICB/USP 
PARA CAROL, COM tOdo MEU AMOR, CUIDAdo E ENTREGA 


\section{AGRADECIMENTOS}

Após esses seis anos de doutoramento, tanta coisa aconteceu... tantas pessoas me ajudaram...

Comecemos com os mais próximos: família! Mãe, Pai, Bela e Marga...muito obrigado por toda a ajuda, pelas orações, pelas risadas e principalmente por dividirem comigo meus momentos de "choradeira" ao falar de um novo amaleke (momento sempre tratado com muito bom humor pelo meu pai). Agradeço também ao sempre solícito e boa gente Pasc por sua ajuda e pelas conversas. Não posso esquecer meus sobrinhos queridos, Vincent e Oliviá...que também me trazem momentos de paz mesmo estando o tio sempre no laboratório.

À minha grande amiga Keity por SEMPRE tentar arranjar espaços em nossas agendas para a atualização dos fofocolelis...sempre 5 agradáveis minutos de conversa...

Ao Roberto por toda a ajuda com as imagens, pelas horas de confocal, pelas conversas e por ter me ensinado a fazer montagens usando o "padrão helicoidal dos distritos de Paris".

A Bety, por ser tão gente boa, sempre acreditar em mim e por me ajudar tanto no momento de PÂNICO no Rio de Janeiro.

Aos "coligados" e "gafanhotos" pelos diversos momentos de alegria: Bruno, Ísis, Stefânia, Cris, Humberto, Marisa Ionta, Marisa Rangel, Lu, Marco, Nati (Suzinha), Marcel, Raquel, Tati, Adam, Amalex, Raji e Carla Lambidinha.

Aos amigos do setor de microscopia eletrônica: Edsão e Gaspar por tanta conversa jogada fora!

À minha grande amiga Vanessa, essa merece muitos agradecimentos! Ali, no front da bancada, foi a pessoa que me viu mais fragilizado, mais chororô. SEMPRE tinha uma frase de incentivo, nunca deixando a peteca cair...obrigado por não permitir que eu enlouquece na frente das bandas do western.

Aos professores Zago e Bauer por aumentarem a minha fascinação por histologia.

A Diabolim por sempre ajudar na hora do sufoco, pelas risadas e por compartilhar tamanha "maldadade". 
Ao Alê, pelo constante contrabando de "muambas" e por sempre ajudar com os artigos impossíveis.

Aos funcionários da Biblioteca do ICB

Às secretárias do departamento

A Bia, pelas conversas nos momentos difíceis

A Dona Nancy por toda ajuda no lab.

A Mich e Evandro que, além de serem ótimos amigos me ajudaram DEMAIS com a citômetria de fluxo.

A Camis por sempre comprar a minha água mineral.

A Vivian pela sua gentileza e conversas

Ao "puliça" Mingau, por permitir (de forma involuntária) que eu o "arrebentasse" nas lutas de boxe.

Aos meus grandes amigos Fábio Sauveiro e Paula...como minha vida seria sem graça sem vocês trabalhando comigo. Amigos irmãos...

A Amandita!! Por tamanha amizade, por me agüentar. Você é legal demais!

Ao parasita rei, por ser mais um amigo que não deixa de me ligar...amigão que sempre vem contar os "causos". O Bêra deve ser lembrado...mesmo ele não me considerando amigo...

À Prof $^{a}$ Dr $^{a}$ Gláucia Maria Machado-Santelli, ou mais conhecida como Chefa. Muito obrigado por tudo o que você me ensinou. Obrigado pelo companheirismo, pela amizade. Obrigado pela ajuda nos momentos difíceis (principalmente no começo do meu doutorado). Obrigado mesmo! 
"O pensamento não é possível sem uma imagem"

(Aristóteles)

“Nós, morfologistas, vivemos em um mundo de cores..."

(Professor Henrique Leonel Lenzi) 


\section{RESUMO}

Do Amaral JB. Células MCF-7 como modelo 3D no estudo de câncer de mama humano. [tese (Doutorado em Biologia Celular e Tecidual)]. São Paulo: Instituto de Ciências Biomédicas da Universidade de São Paulo; 2010.

A cultura celular é caracterizada por permitir a manutenção de células vivas em laboratório independente do organismo que a originou. A utilização desta técnica possibilitou a melhor compreensão dos mecanismos moleculares da célula permitindo importantes avanços científicos no que se refere, por exemplo, a produção de vacinas e a biologia da célula tumoral. A cultura de células em 3-dimensões (3D) derivou-se inicialmente da cultura de células comumente utilizadas (células em monocamada). O diferencial da cultura 3D é permitir que as células explorem as 3dimensões do espaço, aumentando assim as interações com o ambiente e entre as células. Quando crescidas neste sistema, as células formam estruturas denominadas de esferóides multicelulares. Estes esferóides apresentam em seu interior uma heterogeneidade celular, formação de microambiente e exposição diferencial a diversos fatores como nutrientes e oxigênio. Pelo fato destas características se mostrarem muito semelhantes a tumores avasculares in vivo, a cultura de células 3D avançou em diversas linhas de pesquisa tornando-se um modelo bastante utilizado em ensaios radiológicos e de quimioterápicos. Em estudos relacionados à biologia do câncer de mama, vem ganhando espaço a utilização de esferóides para estudos que visam à compreensão da morfogênese do espaço luminal. Inserido neste contexto, o objetivo deste trabalho foi de desenvolver um modelo de cultura 3D que possibilitasse avaliar a formação de esferóides com 3 características não descritas na literatura : a não adição de miméticos de membrana basal; o uso de linhagem tumorais e, por fim , a exposição das células por períodos superiores a 30 dias em cultura 3D. Mostramos que as células MCF-7, nas condições acima descritas, reorganizam-se em estruturas tubulares e acinares. Em ambas situações, a formação do lúmen veio acompanhada pelo estabelecimento de uma camada de células polarizadas, arranjo este muito semelhante ao encontrado em glândulas mamárias. Os resultados apresentados apontam para a existência de uma população de células na linhagem MCF-7 que não estão totalmente comprometidas ao fenótipo tumoral. Mantidos diferenciados, os esferóides de células MCF-7 apontam como um novo modelo para estudos relacionados à formação do lúmen, permitindo assim explorar o papel de diferentes vias como as relacionadas a apoptose, autofagia diferenciação e sobrevivência celular.

Palavras-chave: Culturas de células em três-dimensões. Mama. Neoplasias. Apoptose. Citoesqueleto. Esferóides multicelulares. 


\section{ABSTRACT}

Do Amaral JB. MCF-7 cells as a 3D model in the study of human breast cancer. [Ph. D. thesis (Cell and Tissue Biology)]. São Paulo: Instituto de Ciências Biomédicas da Universidade de São Paulo; 2010.

Cell culture is characterized by maintaining live cells in the laboratory regardless of the organism in which they originated. This technique has contributed to better understanding of molecular cell mechanisms, permitting important scientific advances, for example, concerning vaccine production and tumor cell biology. Three-dimensional (3D) cell culture initially derived from commonly used cell cultures (monolayer cell cultures). As a particularity, a 3D cell culture permits cells to explore the three dimensions of the space thereby increasing cell-cell interactions, as well as interaction with the environment. When grown in this system, cells form structures known as multicelullar spheroids. The interior of these spheroids present cell heterogeneity, microenvironment formation and different exposure to factors, such as nutrients and oxygen. Owing to the fact that these characteristics are very similar to those of in vivo avascular tumors, 3D cell culture advanced in various research lines, thus becoming a widely used model in radiology and chemotherapy essays. In studies related to breast cancer biology, spheroids are becoming widely used in the aim to comprehend luminal space morphogenesis. In this context, the objective here was to develop a 3D culture model that made it possible to analyze spheroid formation using 3 characteristics that have not yet been described in the literature: without addition of basement membrane mimetic, use of tumor cell lines and, lastly, cell exposure for periods longer than 30 days in 3D cell culture. We showed that, in the aforementioned conditions, MCF-7 cells reorganize themselves in tubular and acinar structures. In both situations, lumen formation was accompanied by the establishment of a layer of polarized cells, an arrangement that is very similar to that of breast glands. The presented results suggest the existence of an MCF cell line population not completely committed to the tumor phenotype. When maintained as differentiated, MCF-7 cell spheroids can be a new model for studies regarding lumen formation, thereby exploring the role of diiferent pathways, such as those related to cell apoptosis, autophagy, differentiation and survival.

Keywords: Three dimensional cell culture. Breast. Neoplasias. Apoptosis. Cytoskeleton. Multicelular Spheroids. 


\section{LISTA DE ILUSTRAÇÕES}

Figura 1 - Esquema mostrando o modelo proposto por Harrison para cultivo celular 18

Figura 2 - Esquema mostrando a diferença entre o arranjo espacial de culturas em monocamada e em 3 dimensões.

Figura 3 - Esquema mostrando o modelo proposto por Carrel. 20

Figura 4 - Esquema mostrando o método de cultivo celular descrito por Leighton. .222

Figura 5 - Número de casos de câncer de mama no Brasil e no mundo. 25

Figura 6 - Ilustração mostrando diferentes linhas de pesquisa que podem ser estudadas nos tumores esferóides multicelulares.

Figura 7-Procedimentos utilizados na cultura 3D. 43

Figura 8-Linhagens de mama testadas para a formação de esferóides. 56

Figura 9-Curva de crescimento de células MCF-7. 57

Figura 10 - Fases iniciais da cultura 3D de células MCF-7. 58

Figura 11 -Ensaio para BrDUem esferóides de células MCF-7.

Figura 12 - Desenvolvimento da região medular e cortical nos esferóides de células MCF-7. 61

Figura 13 - Alterações na morfologia dos esferóides ao logo do tempo de cultura 3D. 62

Figura 14 - Células MCF-7 crescidas em monocamada-componentes do citoesqueleto 64

Figura 15-Células MCF-7 crescidas em cultura 3D.-componentes do citoesqueleto.

Figura 16 - Secções opticas de esferóidede células MCF-7 com 75 dias de cultura 3D. 68

Figura 17 - Arranjo luminal em esferóides com 75 dias de cultura 3D. 69

Figura 18 -Ensaio para laminina, BrdU e imagens de microscopia eletrônica de varredura em esferóides diferenciados de células MCF-7. 70

Figura 19 - Microscopia eletrônica de trasmissão de esferóides de células MCF-7-região cortical.........72

Figura 20-Microscopia eletrônica de trasmissão de esferóides de células MCF-7-região medular

Figura 21 - Microscopia eletrônica de trasmissão de esferóides de células MCF-7-região medular .76

Figura 22 -Esferóides de células MCF-7 marcados para M30. .78

Figura 23 - Quantificação por citometria de fluxo de células em processo de morte celular.. .80

Figura 24 - Gráfico de colunas dos resultados de citômentria de fluxo 81

Figura 25 - Imunomarcação para LC3B e sua análise de expressão de proteínas por western blot. .83 
Figura 26 - Imunomarcação para p-AKT e sua análise de expressão de proteínas por western blot ..... 84

Figura 27-Quantificação da expressão das proteínas PAR-4 e p-ERK pela técnica de western blot .85

Figura 28 - Imunomarcação para ADAMTS-1 e sua análise de expressão de proteínas por western blot. .86

Figura 29-Ciclo celular de células MCF-7 obtido por meio de citômetria de fluxo........ .88

Figura 30 - Seleção de esferóides de células MCF-7 diferenciados.. 91

Figura 31 - Seleção de esferóides de células MCF-7 diferenciados. 92

Figura 32 - Crescimento e formação de lúmen em esferóides de células MCF-7 previamente selecionadas. 94

Figura 33 - Esferóides de células MCF-7 de células selecionadas. .95

Figura 34 - Expressão relativa de RNAm para E-caderina em monocamada e em diferentes tempos de cultura 3D. 96

Figura 35 - Esquema mostrando as alterações na morfologia de esferóides de células MCF-7 decorrente do método de cultura em 3D...... 99

Figura 36 - Esquema mostrando vias de sinalização celular onde é possível observar as interações das proteínas analisadas neste presente trabalho. 


\section{LISTA DE TABELAS}

Tabela 1 - Anticorpos utilizados nos experimentos de imunofluorescência. .45

Tabela 2 - Anticorpos utilizados nos experimentos de western blot. 52

Tabela 3 - Média e desvio padrão do número de células encontradas no ensaio de Caspase 9. 81 Tabela 4 - Média e desvio padrão do número de células encontradas no ensaio de ploidia/ciclo celular. .89 
1.1 A CULTURA DE CÉLULAS. 17

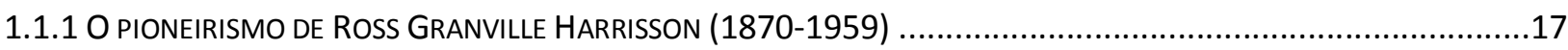

1.1.2 ALEXIS CARREL E O CORAÇÃO IMORTAL DE GALINHA (1873-1944) ...........................................................18

1.1.3 A CULtURA DE CÉLULAS EM 3 DIMENSÕES-HOLTFRETER, MosCONA E LEIGHTON........................................20

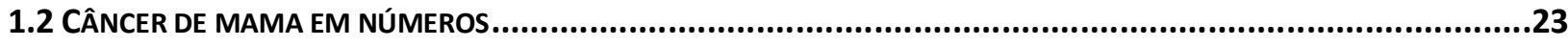

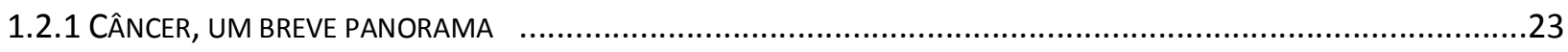

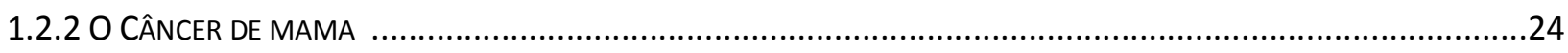

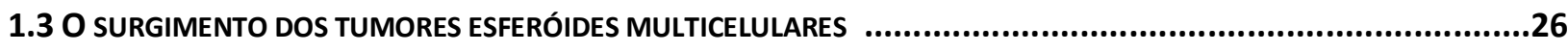

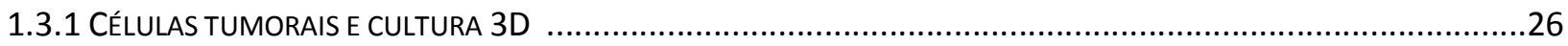

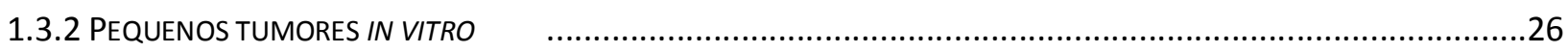

1.4 SIMULANDO A ORGANIZAÇÃO DO TECIDO MAMÁRIO: MORFOGÊNESE LUMINAL E CÂNCER..................................30

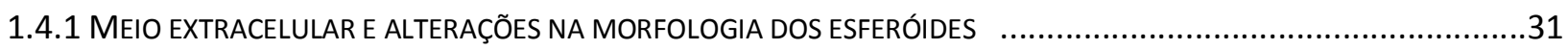

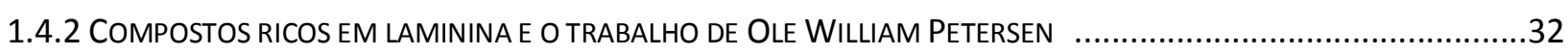

1.4.3 VALERIE M. WEAVER E A REVERSÃO TUMORAL

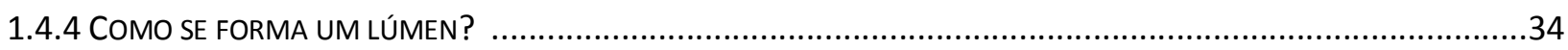

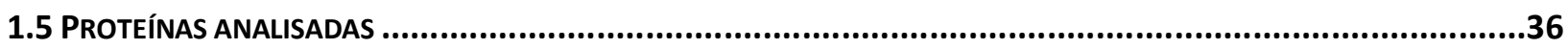

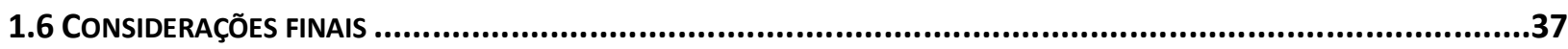

\begin{tabular}{ll}
2 OBJETIVOS & 39 \\
\hline
\end{tabular}

3 MATERIAS E MÉTODOS $\quad 41$

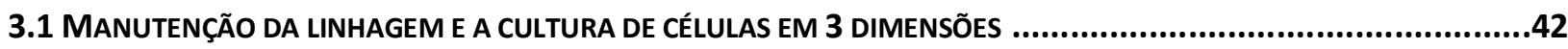

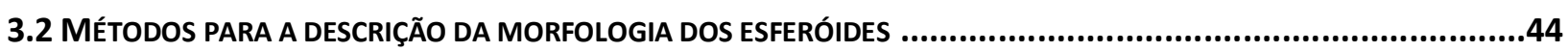

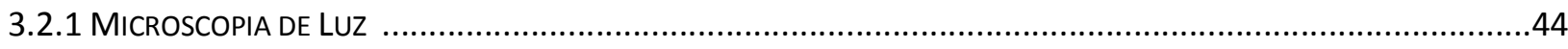

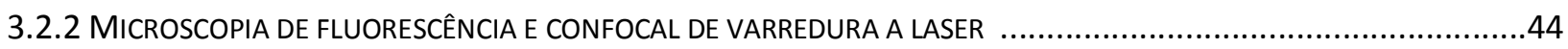

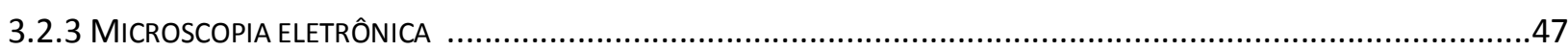

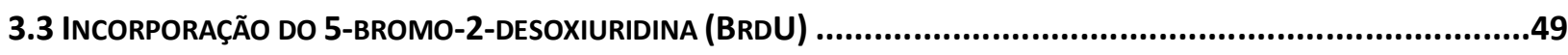

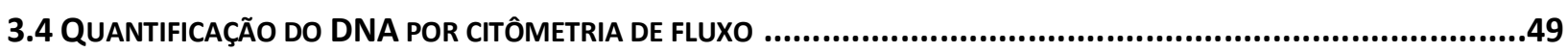

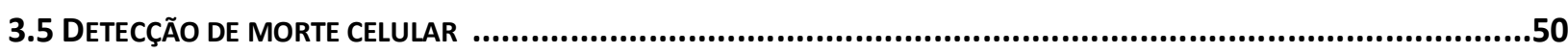

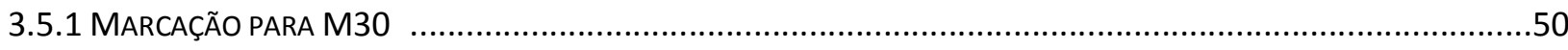

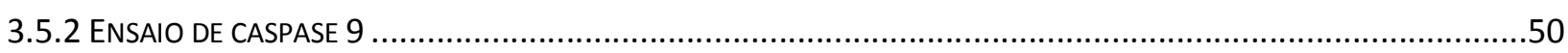

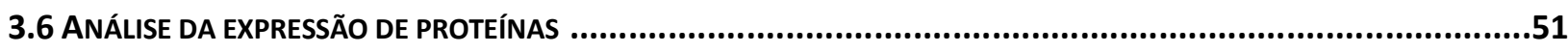

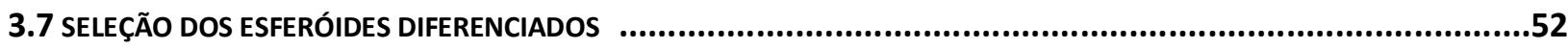

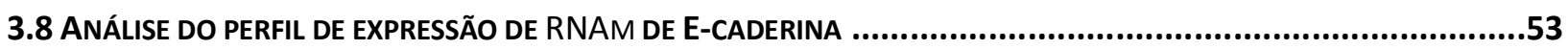

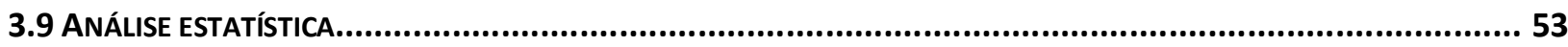




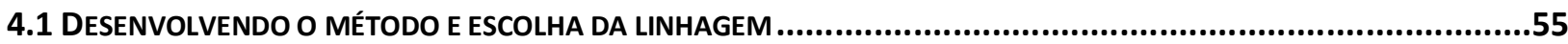

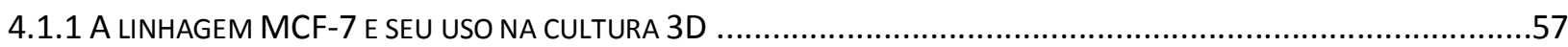

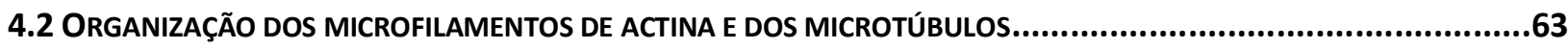

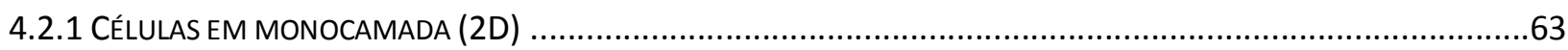

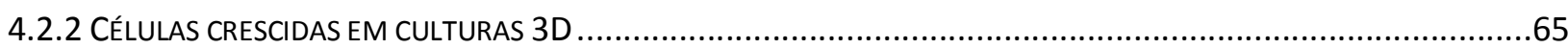

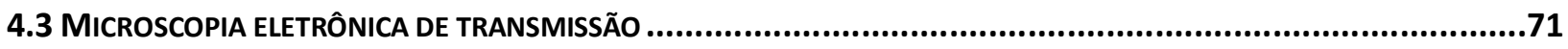

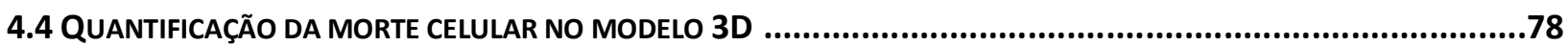

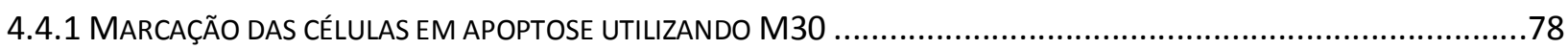

4.4.2 O ENSAIO PARA A DETECÇÃO DE CASPASE 9 POR CITOMETRIA DE FLUXO ….............................................79

4.4.3 QUANTIFICAÇÃO DO PROCESSO DE AUTOFAGIA NOS ESFERÓIDES .........................................................82

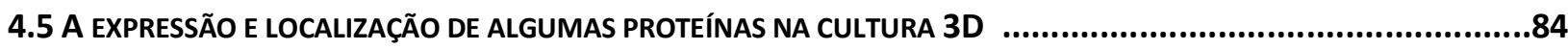

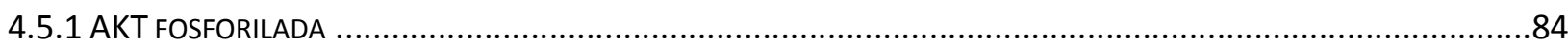

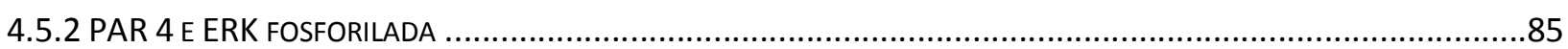

4.5.3 ADAMTS-1

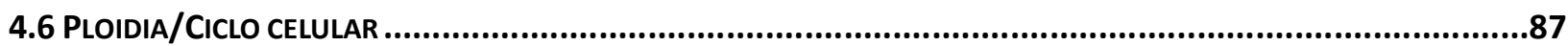

4.7 SELEÇÃO DAS CÉlULAS CRESCIDAS EM CULTURA 3D E A MANUTENÇÃO DE UMA NOVA LINHAGEM........................89

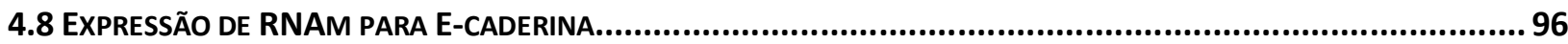

\begin{tabular}{lr}
5 DISCUSSÃO & 97 \\
\hline
\end{tabular}

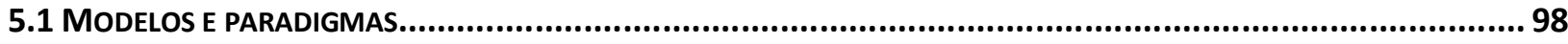

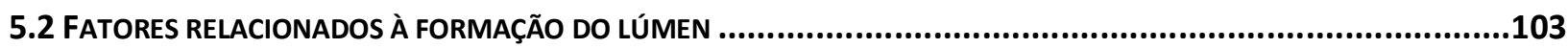

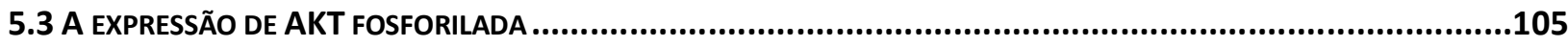

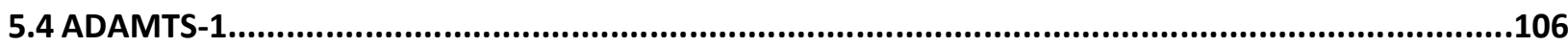

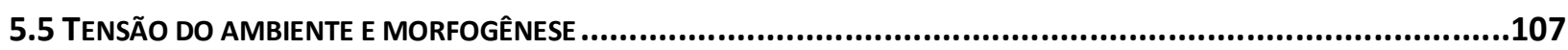

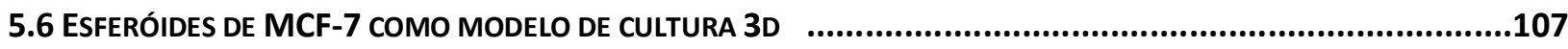

\begin{tabular}{ll}
6 CONCLUSÕES & 108 \\
\hline
\end{tabular}

\begin{tabular}{lr} 
REFERÊNCIAS & 110 \\
\hline
\end{tabular}

\begin{tabular}{ll} 
ANEXOS & 125 \\
\hline
\end{tabular}

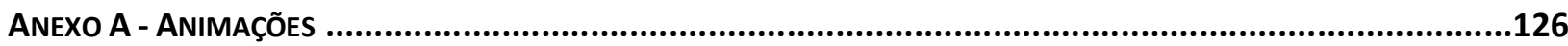

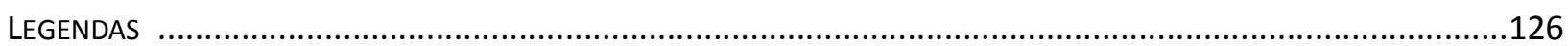

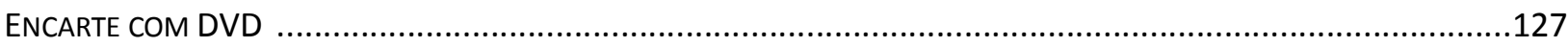

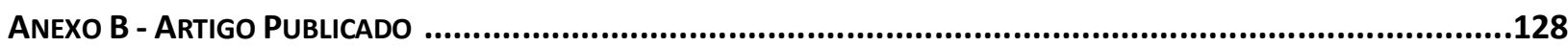

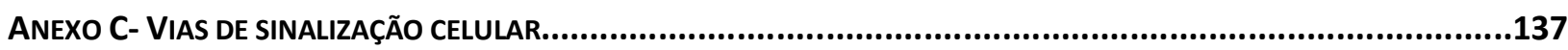




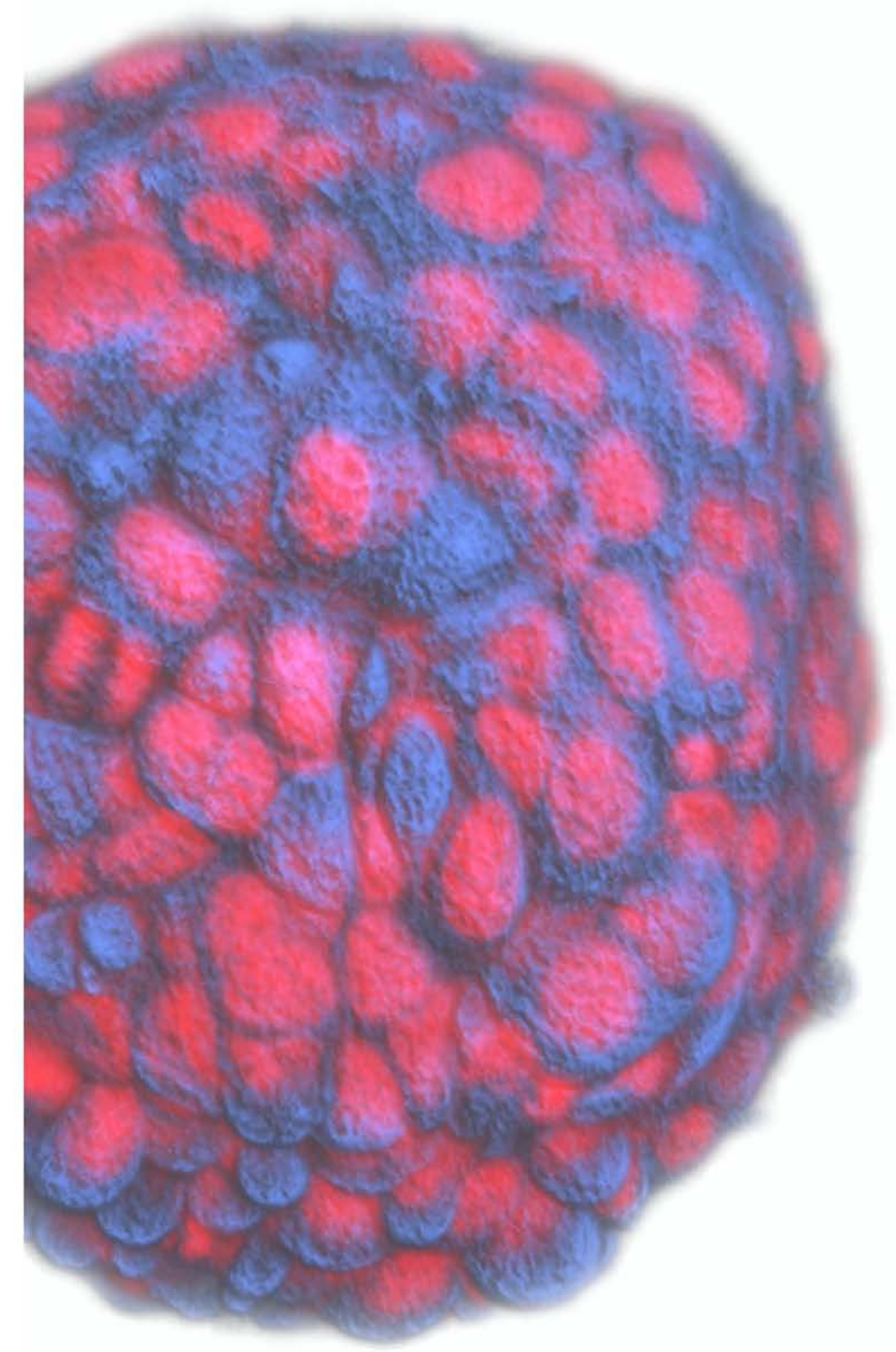

1_INTRODUÇÃO 


\subsection{A CULTURA DE CÉLULAS}

Algumas descobertas científicas mostram se tão usuais e corriqueiras ao cotidiano de qualquer pesquisador atualmente, que, algumas vezes, não damos a sua devida importância. Um exemplo disto é o desenvolvimento da cultura de células. A manutenção de células vivas independentemente dos organismos de origem foi resultado da somatória de trabalhos desenvolvidos por vários autores. Desta forma, não tentaremos aqui descrever todo o processo de descoberta, mas sim, limitaremos o nosso enfoque em algumas inovações inseridas nesta linha de pesquisa que permitiram o desenvolvimento desta tese. Tal panorama abordará temas aparentemente não correlatos como, por exemplo, o coração imortal de galinha, esponjas do mar e até quimeras. Todavia, o núcleo comum destes tópicos se mostrará fascinante e circunstancial para a melhor compreensão deste trabalho.

1.1.1 O pioneirismo de Ross Granville Harrisson (1870-1959)

Influenciados pelas descobertas de Santiago Ramón y Cajal e Camillo Golgi, vários autores, no início do século 20 , debruçavam-se sobre seus resultados (muitas vezes divergentes) com o objetivo de melhor se compreender o sistema nervoso (1). Harrison inseriase neste contexto por trabalhar, entre outras linhas de pesquisa, com processos relacionados à formação de fibras nervosas. Visando compreender como estas se originavam e como ocorria à inervação dos órgãos em direção ao sistema nervoso central, ele desenvolveu um método que possibilitava a retirada de células de embriões de anfíbios mantendo-as vivas em laboratório (2). Esse experimento consistia em colocar um fragmento de tecido (normalmente medula espinhal) imerso em uma gota de linfa de anfíbio vedado entre uma lamínula e uma lâmina de vidro (Figura 1). Tal procedimento mostrou-se bastante eficaz por permitir que Harrison acompanhasse o crescimento e a formação das fibras nervosas, mostrando pela primeira vez que somente o tecido nervoso possuía essa propriedade (uma linha de pensamento na época sugeria que a formação das fibras ocorria no interior dos órgãos e daí ela migraria para a medula). Não limitado a área de neurociências o método de cultura celular assumiu um importante papel na pesquisa científica, sendo seu uso circunstancial para a compreensão da biologia da célula. Os trabalhos de Harrison chamaram a atenção de outro importante cientista, Alexis Carrel o qual iniciava seus estudos com cardiomiócitos. A cultura de células agora avançaria para outro patamar. 


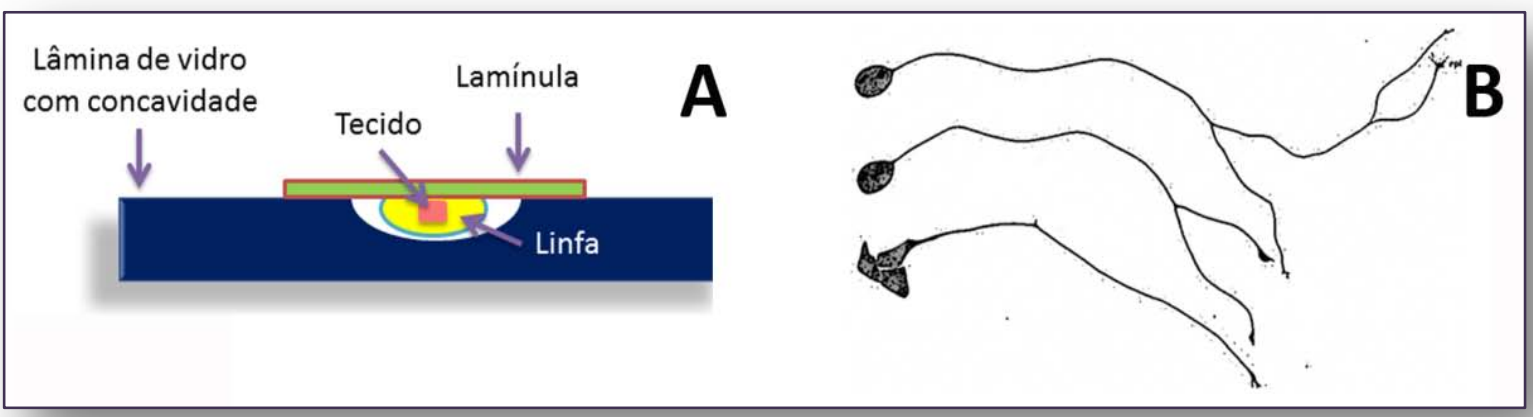

Figura 1 - Método proposto por Harrison para o cultivo celular (A). Primeiros desenhos feitos por Harrison mostrando o crescimento de células nervosas in vitro. FONTE: Figura B modificada de Harrison (1910) (3).

1.1.2 Alexis Carrel e o coração imortal de galinha (1873-1944)

Apesar de possuir notoriedade no meio científico devido aos seus ensaios sobre suturas em vasos sanguíneos (sendo até posteriormente laureado com o prêmio Nobel de Fisiologia e Medicina em 1912), Alexis Carrel possuía particular interesse na viabilidade e manutenção de órgãos in vitro em seus estudos com transplantes. Devido a isso, em paralelo com trabalhos que envolviam a experimentação animal, Carrel iniciou seus estudos com culturas de células. Ao entrar em contato com o trabalho desenvolvido por Harrison, ele focou os seus esforços não somente no estabelecimento da cultura celular in vitro, mas também na manutenção destas por períodos mais longos fora de organismos.

Após enviar um auxiliar para aprender as técnicas de cultura de células no laboratório de Harrison, Carrel começou a desenvolver adaptações que as melhorasse. Inicialmente, adicionou uma série de banhos em soluções salinas para o preparo das culturas. Em paralelo a esse procedimento, substituiu o meio de cultura de linfa de anfíbio para plasma de galinha e desenvolveu uma garrafa de cultura com uma entrada inclinada (Frasco de Carrel), o qual permitia a adição e substituição deste meio com maior facilidade. Outra modificação, talvez a mais importante e inovadora da época, foi a aplicação de um rígido controle de assepsia (sendo esta metodologia muitas vezes mantidas em segredo) (4). 
Com o sucesso de suas culturas em monocamada (Figura 2), A divulgação de seus trabalhos tomou tamanha proporção que muitos cientistas da época atribuíam a ele a descoberta da técnica de cultivo celular. Neste contexto, um de seus assistentes chamado Eberling modificou a técnica desenvolvida por Carrel permitindo que a cultura de células derivadas de corações de galinha fosse sub-cultivada. O sucesso foi tão grande que Eberling repetiu este processo por 34 anos. Surgia assim a lenda do coração imortal de galinha. 0 jornal New York World Telegram telefonava anualmente para Carrel para discutir como estava a manutenção de suas famosas células. Após isso, era escrito um editorial sobre o assunto sendo este muito apreciado pelos leitores, principalmente os que gostavam de ficção científica (5).

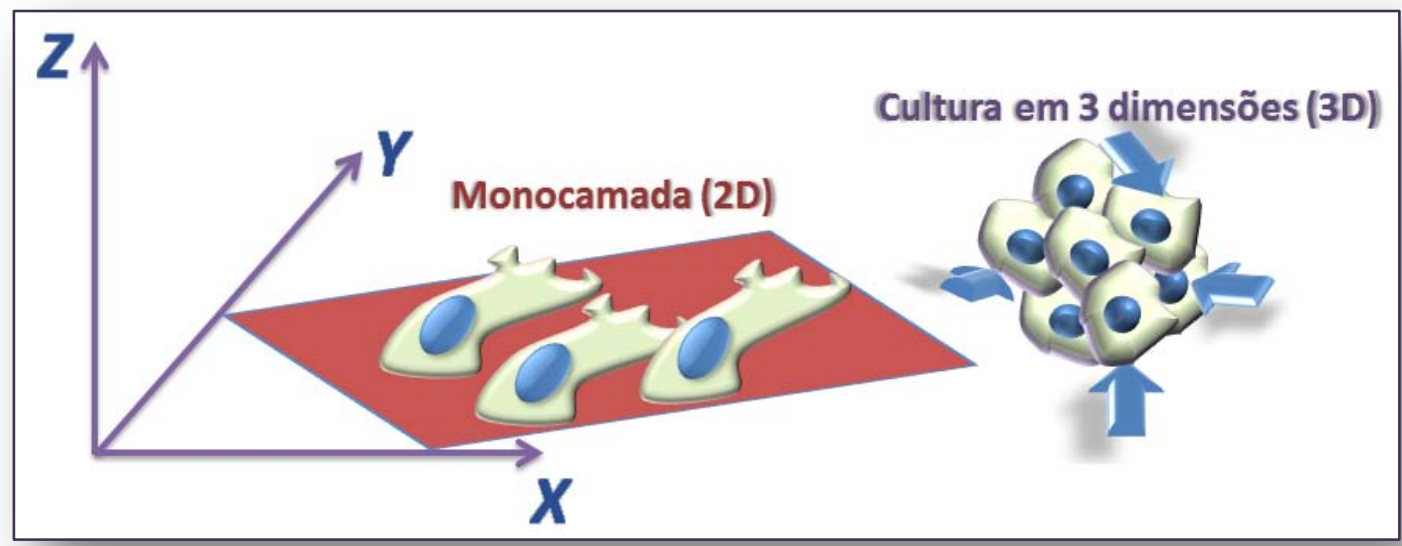

Figura 2 - Esquema mostrando a diferença entre o arranjo espacial de culturas em monocamada e em 3 dimensões.

Foi analisando estas culturas de cardiomiócitos que Carrel notou que o maior contato das células com o meio de cultura tinha relação direta com a viabilidade celular e com uma maior taxa de proliferação. Ele percebeu que, devido a essas características, a região mais central de suas colônias apresentava elevado índice de necrose (Figura 3A). Para resolver este problema ele cultivou os cardiomiócitos sobre uma superfície constituída por fios de seda. Tal adaptação permitiu uma maior interação das células com o ambiente, sendo que este maior contato ocorreu em diferentes planos do espaço (6). Ocorria pela primeira vez uma descrição de uma cultura celular em 3 dimensões (Figura 2 e 3B). 


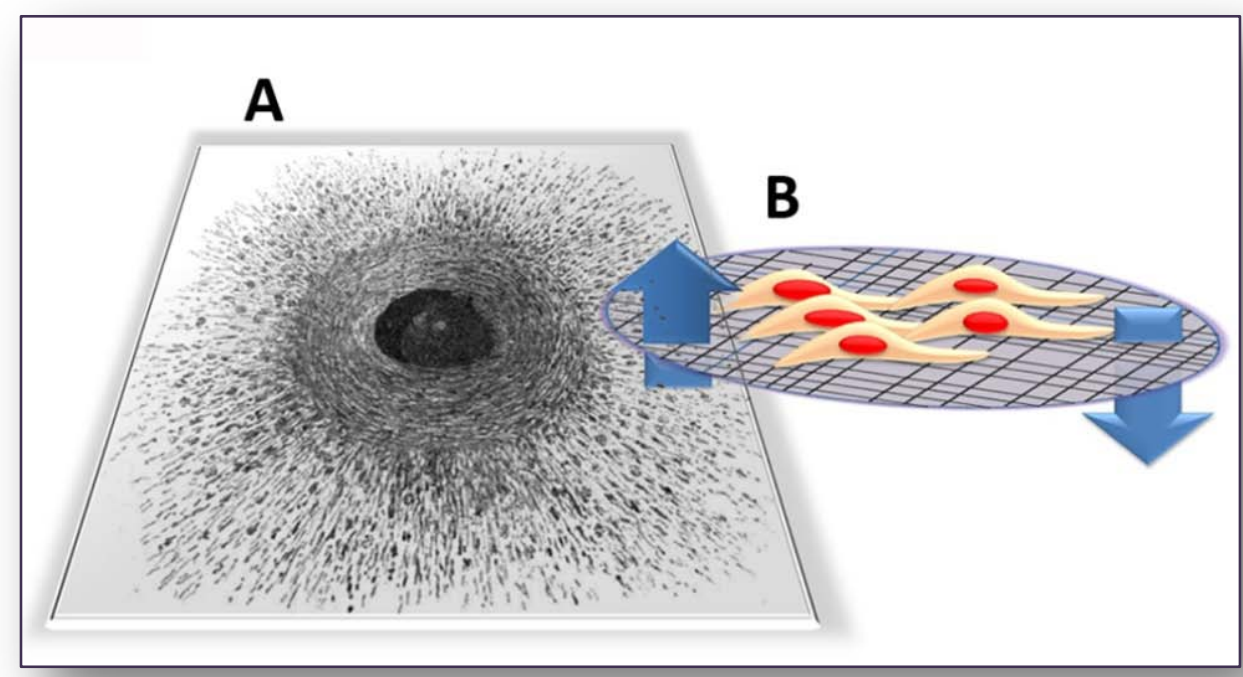

Figura 3 - Desenho feito por Carrel de suas culturas com cardiomiócitos, sendo a região mais escura área com maior índice de necrose (A). Esquema mostrando o crescimento de células sobre um tecido de seda, o qual permitiu maior interação das células com o ambiente (B). FONTE: Figura A modificada de Carrel (1912) (6).

Após os trabalhos de Carrel, o uso e aperfeiçoamento do cultivo celular em monocamada fizeram com que grandes descobertas científicas fossem alcançadas levando, por exemplo, a produção em larga escala de vacinas; maior compreensão dos mecanismos moleculares da célula e, entre outras aplicações, a exploração em maior detalhe da biologia da célula tumoral (5). Passariam aproximadamente 30 anos para que os trabalhos desenvolvidos Johannes Holtfreter, Aron Arthur Moscona e Joseph Leighton explorassem e conseqüentemente divulgassem a cultura 3D no meio científico.

\subsubsection{A cultura de células em 3 dimensões-Holtfreter, Moscona e Leighton}

A obtenção de resultados científicos utilizando fragmentos de tecidos mantidos in vitro ganhou um espaço significativo em estudos da biologia do desenvolvimento. Tal fato ocorreu, principalmente, devido ao sucesso da utilização de embriões nestes estudos. Com o freqüente uso desta metodologia era de se esperar que, em um primeiro momento, a cultura de células em 3 dimensões tivesse como divulgadores alguns embriologistas.

\section{Johannes Holtfreter (1901-1992)}

Devido aos seus trabalhos relacionados à morfogênese do embrião, Holtfreter tornou-se um dos mais reconhecidos pesquisadores na área de biologia do desenvolvimento. A sua 
relação com experimentos que envolvessem a cultura em 3 dimensões ocorreu inicialmente em estudos que mostraram a afinidade entre os tecidos de um organismo, evidenciando neste contexto a importância da adesão celular. Em um dos seus experimentos este autor separou os diferentes folhetos embrionários de um embrião e, em laboratório, os colocou novamente em contato. Além das células se reagruparem nos seus respectivos folhetos, estes agrupamentos celulares possuíam um grau de diferenciação equivalente a sua origem embrionária (7). Em 1944, Holtfreter descreveu um método para a geração de agregados celulares esféricos que consistia em adicionar ágar na superfície de placas de Petri, evitando assim a células aderissem ao fundo da placa (8). Posterior a isso, em 1947, ele derivou o método de formação de culturas 3D adicionando um aparato que permitisse o movimento das placas de Petri, reduzindo ainda mais a interação das células com o substrato (9). As adaptações descritas por Holtfreter são condicionais para a maioria dos métodos relacionados com a cultura de células em 3 dimensões. Seus trabalhos são amplamente citados não somente devido ao seu pioneirismo, mas também pelo fato de seus métodos serem usados até hoje. $O$ uso, neste presente trabalho, de um método semelhante ao descrito por este autor 76 anos depois é somente um dos muitos exemplos da importância de Holtfreter no desenvolvimento da cultura de células em 3 dimensões.

\section{Aron Arthur Moscona (1921-2009)}

Os trabalhos desenvolvidos por Moscona entre 1950 e 1970 tinham como eixo comum a análise de como as células embrionárias individuais se organizavam originando tecidos e órgãos. Utilizando enzimas como tripsina e hialuronidase ele dissociou tecidos de diferentes organismos e percebeu, em uma análise inicial, que as células de órgãos diferentes não se misturavam. Desta maneira, células derivadas de cartilagem de embriões de aves ficavam unidas com suas congêneres e não se misturavam com células de rim, por exemplo (10). Em outro experimento este autor dissociou uma esponja do mar amarela e misturou com células dissociadas de esponjas do mar laranjas, o resultado disso foi a reorganização de 2 grupos distintos, isto é, as células não se misturavam. Moscona também foi um dos pioneiros na produção de quimeras, método o qual consiste na manutenção de células originadas de diferentes organismos os quais permanecem unidas por possuírem moléculas de superfície de membrana que tenham afinidade (11). Dos vários trabalhos que utilizou a cultura de células em 3 dimensões $(12,13)$, um publicado em 1961 (14) chama a atenção por introduzir um método 
que utiliza frascos de Erlenmeyer sob agitação para a produção destes agregados. Muitos autores referem-se a essa técnica até hoje como "método de Moscona". A importância de suas descrições não somente refletem o maior aprimoramento e divulgação de técnicas relacionadas ao cultivo celular em 3-dimensões. Moscona também descreveu a importância do reconhecimento célula-célula é trouxe a luz informações importantes sobre a complexidade inerente aos organismos. Os desdobramentos dos seus resultados levaram a descoberta de estruturas importante nas células, entre elas podemos citar como exemplo as caderinas (15).

\section{Joseph Leighton 1921-1999}

Em 1951, o cultivo de células in vitro era, predominantemente, baseado no crescimento celular em monocamada. Leighton, que na época trabalhava com diagnósticos patológicos e histogênese, viu que mesmo sendo muito importante para essa época, esse paradigma possuía limitações. Para ele, a idéia de um mundo achatado estava distante de um organismo e uma visão reducionista abalizada em estudos com células individuais teria que ser modificado (16). Foi neste contexto que este autor revisitou os trabalhos desenvolvidos por Carrel (6), visando agora desenvolver um método que levasse em conta a tridimensionalidade. Em seu trabalho (17), adicionou células e/ou fragmentos de tecidos em um substrato constituído por esponjas de celulose. Em seguida, Leighton adicionou a esse conjunto um pouco de plasma extraído de embriões de aves. Após a coagulação, os agregados formados por plasma, células e a esponja foram colocado em um recipiente com agitação com posterior adição de nutrientes (Figura 4).

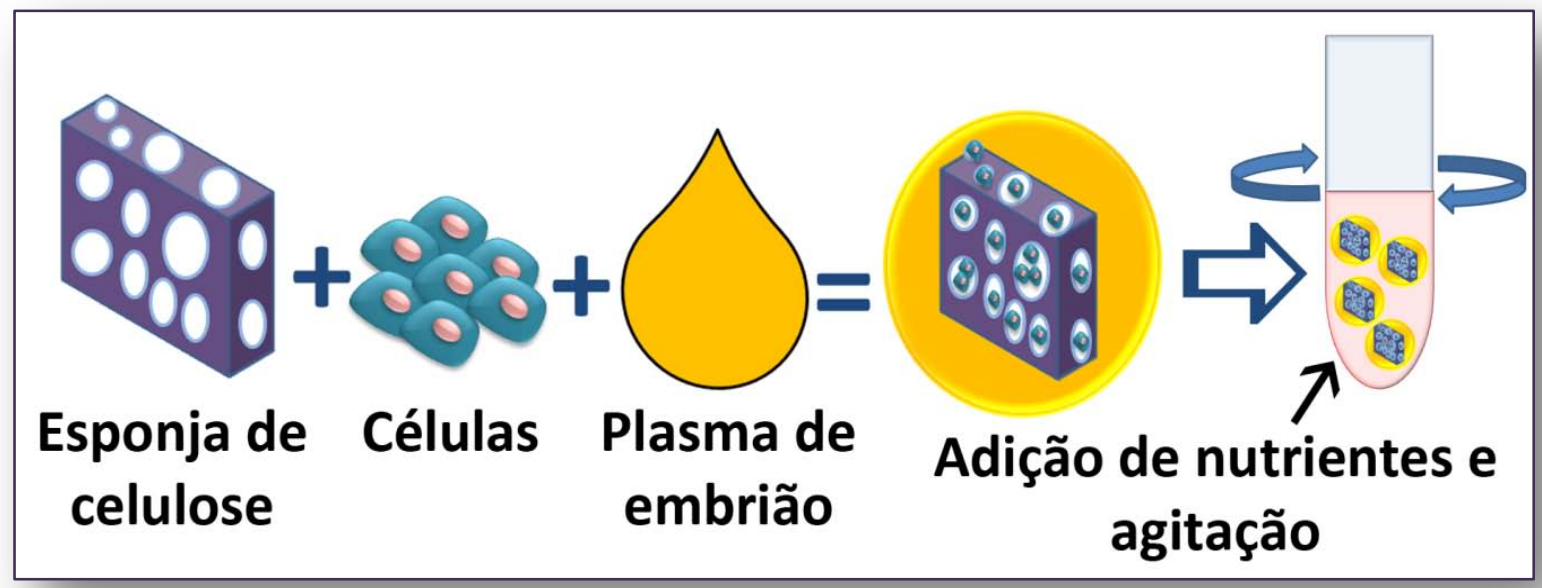

Figura 4 - Esquema mostrando o método de cultivo celular descrito por Leighton. 
A preocupação com a manutenção da arquitetura tecidual fez com que Leighton se diferenciasse dos autores descritos até agora. Em seu trabalho de 1954 (18) ele descreveu pela primeira vez alguns aspectos importantes da cultura em 3 dimensões, sendo eles:

- $\quad$ O arranjo tridimensional possibilita que células migrem para todas as direções.

- $\quad$-O sistema 3D permite um aumento da superfície celular.

- A difusão presente no interior dos agregados pode reter fatores secretados pelas células

- $\quad$ O modelo pode permitir um gradiente de difusão capaz de gerar uma alteração na morfologia celular, podendo iniciar processos relacionados à diferenciação tecidual

O gradativo aprimoramento nas técnicas de cultura de células em 3-dimensões fez com que, após os trabalhos de Leighton, houvesse uma distinção muito clara entre os resultados em monocamada e os desenvolvidos em ambiente 3D. A decorrente irradiação desta técnica em diferentes métodos e aplicações é somente uma amostra da importância daquele ano de 1951 onde, em laboratório, a cultura de células começaria a se aproximar a experimentos in vivo.

Assim, após essa breve descrição sobre os trabalhos iniciais envolvendo a cultura de células mostraremos, na próxima seção, outro importante tema que será abordado nesta tese: o câncer de mama.

\subsection{CÂNCER DE MAMA EM NÚMEROS}

\subsubsection{Câncer, um breve panorama}

Alguns números obtidos na última estatística fornecida pela Organização Mundial de Saúde mostraram que em 2008 o número de novos casos de câncer no mundo foi de 12,7 milhões de pessoas, sendo que destas 7,6 milhões vieram a óbito. Interessante mencionar que na mesma fonte citada alguns números chamam a atenção (19): 
1ㅇ) $70 \%$ destas mortes ocorrem em países sub-desenvolvidos e em desenvolvimento.

20) $1 / 3$ dos cânceres quando precocemente diagnosticados e tratados podem ser curados

3ㅇ 11,5 milhões de pessoas poderão morrer de algum tipo de câncer até 2030 , dado este que mostra uma crescente no número de mortes ao longo dos anos.

Em se tratando de um problema de saúde pública também no Brasil (com uma projeção de 489.270 novos casos de câncer em 2010 segundo o Instituto Nacional do Câncer (20), tornase cada vez mais necessário medidas que levem a diminuição do número de óbitos bem como a melhoria no diagnóstico/tratamento. Dentre essas medidas, estudos relacionados com a biologia da célula cancerosa são de significativa importância, haja visto que muitos aspectos desta doença ainda permanecessem sem resposta.

A versatilidade e autonomia das células metazoárias muitas vezes é decorrente da presença, em seu interior, de um genoma completo de todo o organismo. Tal fato pode se tornar um risco devido células individuais deste organismo ter acesso a informações em seu genoma às quais normalmente não teriam. O acesso a esses genes o pode transformá-los em alvos para diversos mecanismos que alterem sua estrutura e, assim, a informação contida no genoma (21). O desenvolvimento do câncer ocorre neste contexto, pois, durante um processo que envolve muitas etapas, o genoma de células cancerosas iniciais adquire mutações em proto-oncogenes, genes supressores de tumor ou qualquer outro que controle diretamente ou indiretamente a proliferação celular. Diferentes combinações destas mutações (inclusive as decorrentes de alterações epigenéticas),são capazes de contribuir para a transformação neoplásica, sendo este processo uma característica comum a mais de 100 tipos de cânceres humanos (22-25).

\subsubsection{O Câncer de mama}

O câncer de mama possui uma etiologia variada, sendo influenciada tanto por fatores genéticos bem como ambientais (26). A origem deste tumor se dá, na maioria das vezes, por mutações em células epiteliais constituintes dos túbulos e lóbulos mamários (27). 
Estudos epidemiológicos reforçam a importância deste tipo de câncer. No Brasil, segundo projeções do Instituto Nacional do Câncer, para o ano de 2010 são esperados 49.240 novos casos (20). Quando comparado com outros cânceres, este mostra-se como o de maior incidência na população do sexo feminino (Figura 5).

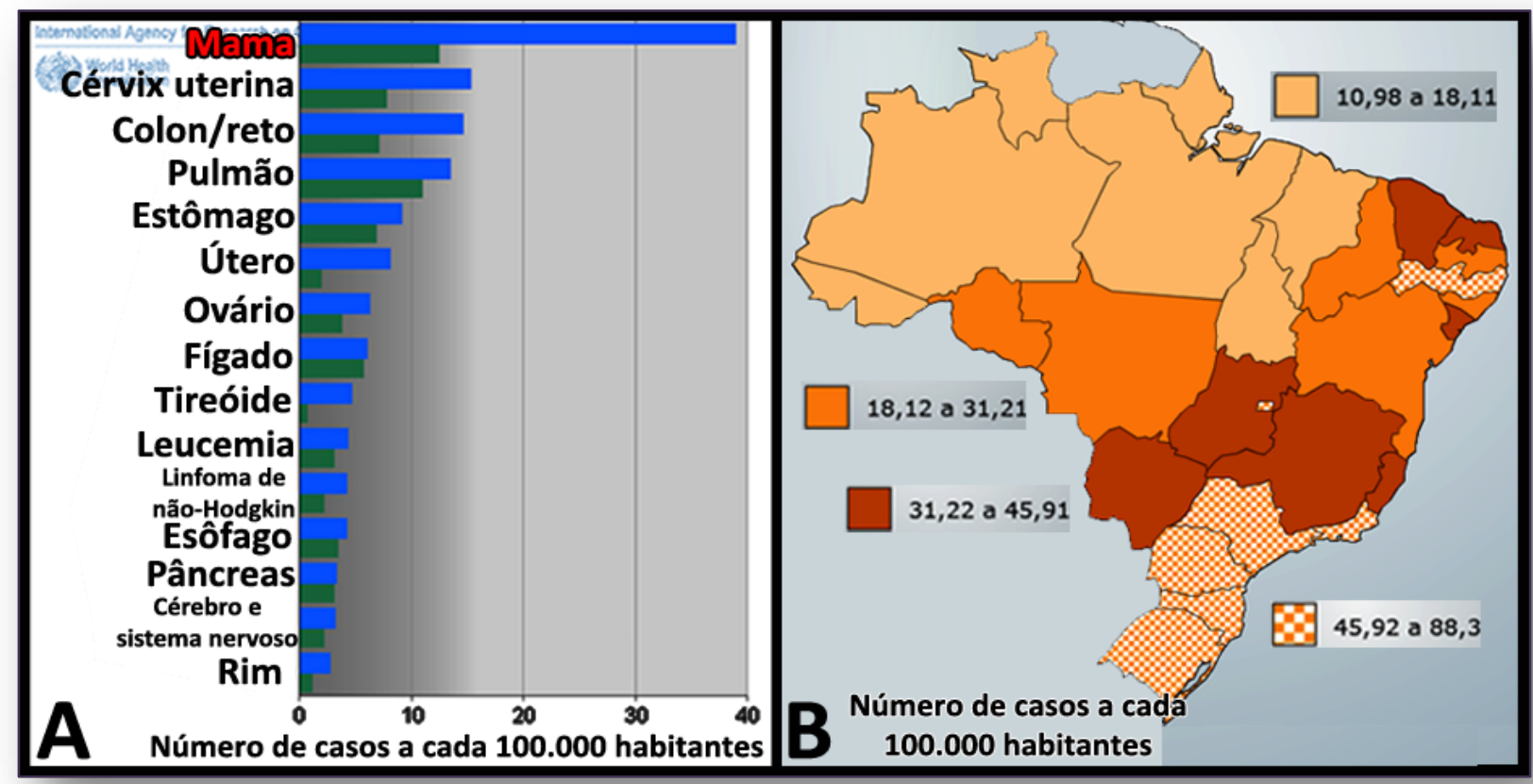

Figura 5 - Número de casos de câncer de mama (em azul incidência e em verde mortalidade) no mundo segundo a Organização mundial de Saúde (ano 2008) (A) e no Brasil, segundo projeção do Instituto Nacional do Câncer para o ano de 2010 (B).

Fontes: Modificado de A (19) e de B (20).

O estudo do câncer mama bem como o de outros tipos de cânceres, tem mostrado que essas patologias possuem alta heterogeneidade no que refere a aos tipos celulares e a suas origens no interior dos tecidos. Além disso, essa diversidade se estende também à desregulação de muitas vias que governam fundamentalmente processos como morte, proliferação e diferenciação (28). Tal fato exige cada vez mais o desenvolvimento de diferentes frentes de pesquisa as quais visam trazer à luz maiores informações sobre essas doenças. Pensando nisto, é muito lógico que a cultura de células em 3 dimensões também tenha (e tem) se mostrado como uma ferramenta eficaz para estes estudos. Voltaremos agora para o ano de 1967, onde McAlister e seus colaboradores (29) observaram uma peculiaridade nas células cancerosas que estudavam: o crescimento de colônias em uma superfície de ágar, fato este não compartilhado por suas congêneres com fenótipo normal. 


\subsection{O SURGIMENTO DOS TUMORES ESFERÓIDES MULTICELULARES}

\subsubsection{Células tumorais e cultura 3D}

A utilização da cultura de células tumorais crescidas em ambiente tridimensional já era feita desde os trabalhos iniciais desenvolvidos por Moscona(11) ,o qual analisou a interação de células de melanoma em agregados celulares que ele denominou de quimeras. Esses agregados apresentavam uma morfologia semelhante aos tumores que os originaram, mantendo até as propriedades invasivas quando estas eram crescidas em associação com células normais. Já Halpern e seus colaboradores (30) mostraram que o arranjo destes agregados bem como a sua tumorigenicidade eram diferentes quando se utilizava células normais do que quando se utilizava células tumorais. Como já comentado, foi o trabalho de McAllister e colaboradores (29) que realmente abordou o comportamento diferenciado das células malignas. A morte das células normais na presença de uma superfície de ágar era, para esses autores, uma prova das células normais dependia da ancoragem desta célula ao substrato. Sabia-se já naquela época que células derivadas de tumores malignos perderiam essa dependência de ancoragem, sendo esta característica então refletida na sobrevivência das células na cultura 3D.

Apesar de iminente, a sistematização e padronização de um modelo que mimetizasse o ambiente e metabolismo de um tumor ainda não tinham sido concretizadas. Isso iria mudar após os trabalhos desenvolvidos por Sutherland e seus colaboradores em 1970.

\subsubsection{Pequenos tumores in vitro}

\section{O surgimento dos esferóides}

A criação de modelos que permitissem testes de efeito e de intensidade de radiação direcionou Robert M. Sutherland e outros pesquisadores à utilização de cultura de células em 3D. Trabalhando inicialmente com linhagens derivadas de pulmão de Hamster, esse grupo desenvolveu uma técnica que utilizava frascos que permitiam um fluxo do meio de cultura no seu interior (Frascos giratórios-spinner flasks), impedindo assim adesão das células com o substrato. Como conseqüência, os agregados de células assumiram uma morfologia esférica a qual fez com que esses autores os denominassem de esferóides multicelulares $(31,32)$. Como a formação de esferóides também era observada em células derivadas de carcinomas mamários 
bem como de outros cânceres (33), iniciou-se o desenvolvimento de estudos que buscassem similaridades entre os resultados encontrados na cultura 3D com os encontrados in vivo. $\mathrm{O}$ desdobramento destes experimentos levou o grupo de Sutherland a conseguir mostrar pela primeira vez que, quando submetidos a um tratamento com radiação, os esferóides ${ }^{1}$ multicelulares apresentavam curvas de sobrevivência celular análogas às de tumores sólidos $(31,34)$. Diferentes linhas de pesquisa agora focariam um aspecto importante deste modelo- a heterogeneidade celular.

Em ambiente 3D as células não são igualmente expostas ao meio. Tal fato faz com que haja a formação de microambientes que, no interior dos esferóides, podem levar a seleção de diferentes grupos celulares (35). Decréscimos regionalizados de tomada de oxigênio e nutrientes podem levar, neste contexto, a formação de áreas de necrose nestes esferóides. Ao se olhar para essas características, paralelos com tumores sólidos (principalmente avasculares) são inevitáveis. Diferentes frentes de análise que exploram essas similaridades foram desenvolvidas, sendo algumas representadas na Figura 6.

\section{Esferóides: semelhanças entre modelos, vantagens e aplicações}

Como já comentado, estudos envolvendo a terapia radiológica foram uma das primeiras linhas de pesquisa bastante exploradas por meio de cultivo celular 3D. Resultados mostrando as diferenças entre o ambiente 2D e 3D, principalmente no que se refere a resistência das células (36), direcionaram esta abordagem experimental para diversas linhas de pesquisa, como por exemplo estudos relacionados a radiação ionizante, a geração de radicais livres, inibição da respiração celular e toxicidade preferencial em regiões de hipóxia $(37,38)$. Posteriormente ao grande número de trabalhos produzidos na década de 70 e 80 , experimentos que envolvam cultura 3D e ensaios radioterápicos atualmente vêm trazendo informações importantes a respeito do papel de substâncias radiosensibilizantes (39) e radioprotetoras (40) em algumas vias de sinalização celulares. Outros autores (41) mostraram que o arranjo da cromatina de células organizadas em esferóides é alterado, apontando assim para uma inter-relação entre morfologia e radiosensibilidade celular.

\footnotetext{
${ }^{1}$ No decorrer de todo o texto será utilizado o termo esferóide ao invés de tumores esferóide multicelulares
} 


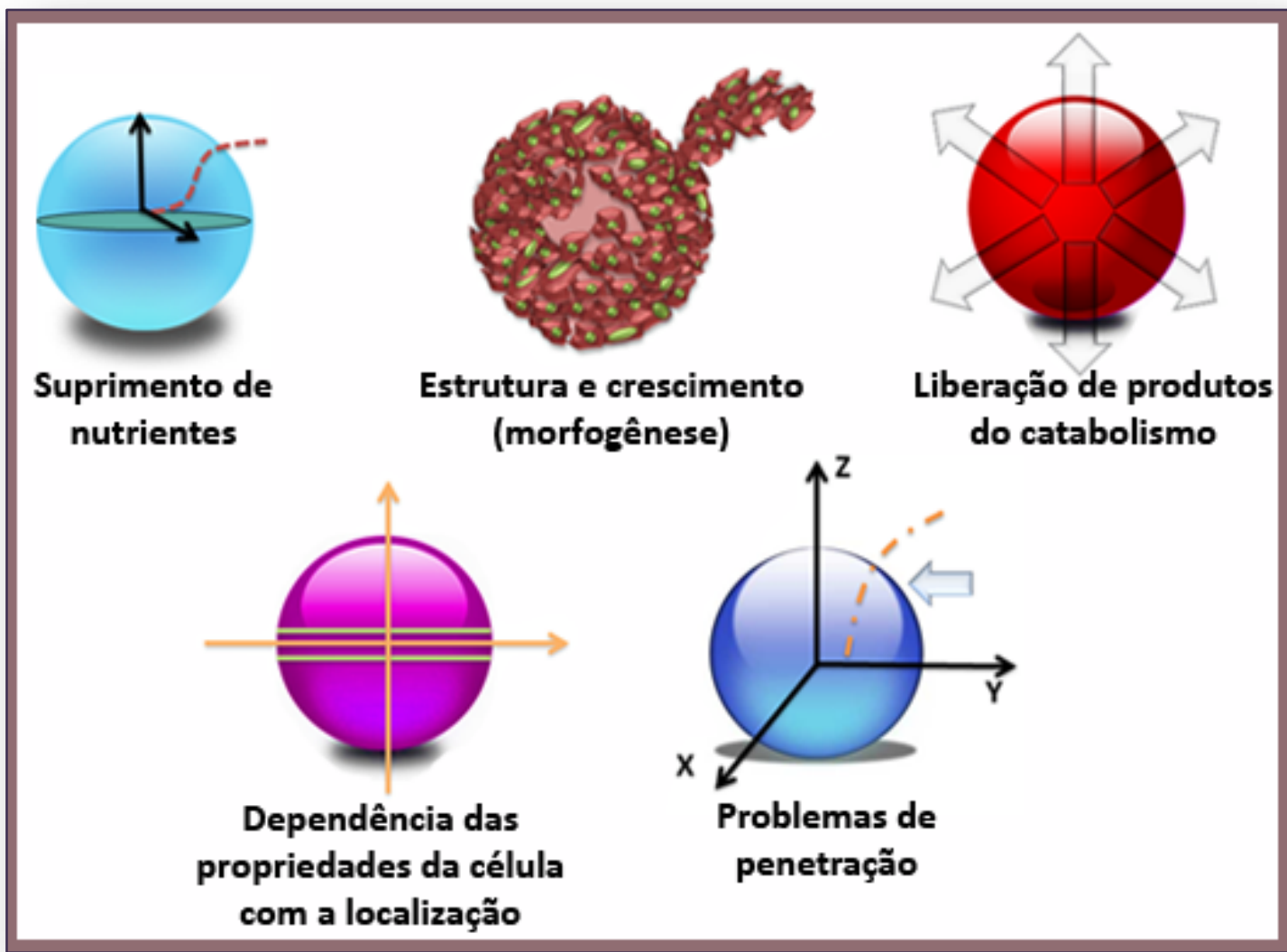

Figura 6 - Ilustração esquemática mostrando diferentes linhas de pesquisa que podem ser estudadas nos tumores esferóides multicelulares (42).

Aplicação importante dos esferóides é também o seu uso em ensaios que envolvam testes de sensibilidade a drogas. Inicialmente, este tipo de aplicação esteve sempre associado à cultura de células crescidas em monocamada. Todavia, percebeu-se que o efeito de algumas concentrações de drogas não tinham equivalência in vivo dos valores encontrados na cultura 2D. Muitas evidências têm mostrado que células arranjadas em esferóides, principalmente as localizadas no interior destes agregados, são muito mais resistentes a agentes citotóxicos do que células em suspensão na cultura. Dos vários trabalhos inicialmente desenvolvidos, podemos citar como exemplos estudos que mostraram maior resistência aos quimioterápicos doxorrubicina, vincristina e mitoxantrona em esferóides do que em linhagens em monocamada (43-45). Tal diferença não é apenas uma resultante de problemas de difusão destas drogas no interior do esferóide. Fatores como alterações de $\mathrm{pH}$, hipóxia e diferentes taxas de proliferação celular também estão envolvidos nesta maior resistência $(46,47)$. A presença destes diferentes fatores faz com que o modelo de cultura de células em 3D seja o modelo in vitro que mais se 
aproxima com modelos in vivo (48-50), pois, similarmente ao já mostrado em ensaios de radioterapia, esferóides também apresentam curvas de resistência a drogas semelhantes às encontradas em alguns tumores sólidos (51-53).

A cultura de esferóides também se destaca por conseguir restabelecer características morfológicas e funcionais de seu equivalente tecido in vivo. Um dos fatores responsáveis por isto é a crescente produção de componentes de matriz extracelular o qual permite a criação de uma complexa rede tridimensional onde protagoniza um grande número de interações célulacélula bem como célula-matriz. A descrição e localização de fatores (pato)fisiológicos, bem como penetração, ligação e bioatividade de drogas podem ser então simulados nestes modelos que exploram esse arranjo 3D $(54,55)$.

Tanto a similaridade com regiões avasculares de pequenos tumores, quanto com as regiões intervasculares de grandes tumores sólidos tornam o modelo 3D peculiar. Como explicado anteriormente, tal característica mostrou-se muito útil em estudos que envolviam testes com radioterapia. Adicionado a este fato, os esferóides mostram uma cinética de crescimento que não somente podem ser calculada pela equação de Gompertz, como também por diferentes outros modelos matemáticos relacionados ao crescimento de tumores $(56,57)$. Conseqüentemente, são também estabelecidos paralelos no tocante ao gradiente de proliferação. Como nos tumores, a periferia dos esferóides (região cortical) é o local onde ocorre o maior índice de proliferação celular. Á partir deste ponto, se traçarmos uma linha radial em direção ao centro (região medular do esferóide) torna-se evidente o crescente número de células que não estão em ciclo celular. Ao redor de $400 \mu \mathrm{m}$ da superfície do esferóide, é possível observar o início de áreas de necrose. A complexidade do modelo ocorre devido à presença de microambientes com diferentes exposições a nutrientes, fatores de crescimento e a trocas gasosas. O agrupamento de células também altera o fluxo de liberação de catabólitos, tornando a sua forma de liberação bastante heterogênea. Estas variações afetam diretamente a fisiologia celular tanto em esferóides quanto em tumores. Desta forma, experimentos com esferóides podem in vitro mimetizar alguns aspectos da complexidade tumoral $(50,58,59)$

A cultura de esferóides também permite que em laboratório se utilize do uso de cocultivo de diferentes linhagens celulares (esferóides heterólogos). Tal abordagem possibilita 
crescer em associação uma célula de origem tumoral com diversas outras derivadas de linhagens normais. A adição, por exemplo, de fibroblastos, células endoteliais e células do sistema imune permite simular cada vez mais uma maior interação estroma-parênquima, características inerente de um arranjo tecidual (60-62).

Com o gradual aperfeiçoamento da técnica para a produção de esferóides, cada vez mais se observa a utilização deste modelo como método de varredura de alto desempenho. Isso significa que, anteriormente a grandes testes clínicos, as indústrias estão utilizando esferóides com o objetivo de validar o efeito de determinados compostos. Tal mudança é decorrente de alguns fatores:

- Redução de custos $(63,64)$

- Inadequação de determinados modelos animais para a compreensão de vias de sinalização de células humanas (65)

- Aspectos bioéticos relacionados ao uso de animais (55)

- Em determinadas condições, resultados obtidos em cultura 2D mostram-se muito distantes dos organismos analisados exigindo uma gradual substituição deste modelo por culturas 3D $(66,67)$.

Em síntese, é possível verificar que as muitas similaridades com modelos in vivo habilitam o uso esferóides como uma eficiente ferramenta de estudo in vitro. É evidente que tanto a cultura em monocamada bem como modelos animais possuem um importante papel na pesquisa científica. Todavia, por possuir característica de ambas as técnicas, o seu crescente uso se justifica. Neste contexto, mostraremos na próxima seção a importância deste modelo em estudos relacionados ao câncer de mama e na morfogênese de estruturas luminais.

\subsection{SIMULANDO A ORGANIZAÇÃO DO TECIDO MAMÁRIO: MORFOGÊNESE LUMINAL E CÂNCER}

Como mostrado anteriormente, a alta incidência de casos bem como o elevado número de mortes mostram a importância da melhor compreensão dos mecanismos relacionados ao câncer de mama. Dentro deste objetivo, diversas frentes de pesquisa vêm utilizando a cultura de células em 3-dimensões visando, por exemplo, a obtenção de informações sobre: 
- Papel das forças tensionais no arranjo tridimensional (68)

- Processos relacionados à regulação da polaridade ápico-basal tanto epitélio normal quanto em epitélio tumoral (69).

- Arquitetura e homeostase tecidual (70).

- Interferência na expressão fenotípica decorrente de interações célula-célula e célula matriz (71).

- A formação e manutenção do arranjo glandular associado à presença de um lúmen e a sua desorganização decorrente de genes relacionados ao câncer (72).

1.4.1 Meio extracelular e alterações na morfologia dos esferóides

A utilização de células derivadas de tecidos mamários já vem ocorrendo desde as primeiras tentativas de cultura de células em 3D. Um dos primeiros experimentos utilizando essas células foi feito por Krystyna Dabrowska-Piaskowska em 1959 (73). Esta autora dissociou diversos tipos de adenocarcinomas (inclusive mamário) e percebeu que quando as células formavam agregados elas desenvolviam a "capacitação histoformativa", que segundo a autora seria a capacidade das células se organizarem de maneira semelhante ao tecido que a originou. Posteriormente, com os avanços na técnica de cultivo, muitos trabalhos mostravam que a adição de componentes de matriz extracelular possibilitava modificações na morfologia celular. Tendo em vista estes processos, no final da década de 70, Jason Yang e seus colaboradores (74) perceberam que células derivadas de tecidos mamários (normal e tumoral) se arranjavam diferencialmente em ambiente 3D. Segundo eles, a presença de colágeno no meio de cultura possibilitou uma maior sobrevivência das células durante o experimento. Associado a isto, também se verificou alterações morfológicas que remetiam a formação de dutos, arranjo este que era somente encontrado in vivo. Passado alguns anos, Hall e seus colaboradores (a maioria integrantes do grupo de Mina Bissell) perceberam que ao utilizar método semelhante com células de mama normais era possível observar um arranjo luminal (75). Eles observaram que na presença de colágeno tipo 1 as células se organizavam de forma polarizada, formavam junções e a suas regiões apicais se voltavam para um espaço comum de maneira semelhante ao de uma glândula mamária. Desta maneira, cada vez mais, a pesquisa em câncer de mama se aproximava da geração modelos que mimetizavam a formação de lúmen. A adição de um novo 
componente a esse sistema modificaria de forma significativa a produção de esferóides luminais.

\subsubsection{Compostos ricos em laminina e o trabalho de Ole William Petersen}

A membrana basal é uma matriz extracelular especializada que está intimamente relacionada com diferentes tipos celulares, entre eles as células epiteliais. Possuindo muitas funções biológicas, a membrana basal possui na sua constituição colágeno tipo IV, lamininas, fatores de crescimento, sulfato de heparam, proteoglicanas entre outras substâncias (76). A busca por uma suplementação de meio de cultura que utilizasse estes compostos mostrava-se importante, haja visto que estes podem afetar diretamente a polarização celular, formação de lúmen e possuem papel ativo em processos relacionados a progressão tumoral $(21,77)$. Todavia, até meados da década de 80 , a extração destes compostos era ineficiente sendo que muitas vezes o produto coletado se mostrava insolúvel (76). Como resultante de uma série de trabalhos (78), Hynda K. Kleinman (79) purificou um composto rico em componentes da membrana basal, o qual era extraído de um tipo de condrosarcoma denominado de tumor de Engelbreth-Holm Swarm. Conhecido comercialmente como Matrigel ${ }^{\circledR}$, esse gel rico em laminina gradativamente vem se tornando circunstancial em experimentos que envolvessem esferóides de células mamárias. O trabalho de Ole Willian Petersen iniciaria uma nova fase, a qual se tornaria um paradigma até os dias atuais.

Petersen e colaboradores (80) perceberam que a diferenciação decorrente do ambiente 3D e da adição de colágeno tipo 1, mostrava-se pobre quando comparado com a organização tecidual. Devido a esse panorama, estes autores resolveram substituir a suplementação de colágeno por Matrigel ${ }^{\circledR}$. O experimento consistia em verificar o arranjo de células mamárias normais e tumorais em frente a essa nova condição. Os resultados encontrados mostraram que linhagens normais (MCF-10A e HMT-3522) bem como células extraídas de tecido mamário rapidamente assumiam um arranjo acinar. As células reorganizavam-se de forma polarizada, com junções celulares bem estabelecidas e apresentando também uma maior expressão de glicoproteínas na região apical bem como colágeno tipo IV na região basal. Quando comparadas com as células que eram crescidas em monocamada, ficava evidente que a presença do Matrigel (BD Biosciences, Bedford, MA, Estados Unidos) e o ambiente 3D atuavam na diferenciação dos esferóides de células normais. Todavia, quando este protocolo era aplicado 
em células derivadas de tumor de mama e em linhagens tumorais, não era observada nestas células nenhuma diferenciação. Dois pontos devem ser aqui enfatizados:

- A utilização de Matrigel, após este trabalho, consolidou-se na pesquisa com esferóides de células mamárias por permitir em um curto espaço de tempo diferenciação e formação de estruturas acinares.

- Aspectos que diferenciassem linhagens tumorais de normais poderiam ser agora mais detalhados, pois vias de sinalização celulares eram diferentemente ativadas em ambiente rico em laminina.

Assim, os resultados apresentados pelo grupo da professora Mina Bissell instigavam a comunidade científica a voltar o seu olhar para a matriz extracelular. Eles mostrariam, 5 anos mais tarde, que no contexto da biologia do câncer isso seria de grande importância.

1.4.3 Valerie M. Weaver e a reversão tumoral

Em 1987, Briand e colaboradores estabeleceram em laboratório uma nova linhagem celular chamada de HMT-3522. Originaria de uma fibrose da mama, essa célula caracterizava-se por manter-se diplóide após várias passagens e também por não apresentar tumorigenicidade (81). O seu freqüente uso fez que alguns pesquisadores selecionassem a partir dela duas novas linhagens celulares: a não tumoral S1 e a tumoral T4-2. Weaver et al. (82) iniciaram os seus trabalhos crescendo ambas as células em monocamada e cultura 3D. Apesar destas células possuírem uma origem comum, somente as células S1 se reorganizaram em estruturas acinares quando crescidas em culturas 3D com Matrigel ${ }^{\circledR}$. Já as células T4-2, nas mesmas condições, mostraram-se extremamente desorganizadas. A partir destes resultados, este grupo verificou que um receptor de matriz extracelular-a integrina $\beta 1$-era muito mais expressa em T4-2 do que a linhagem não tumoral S1. Utilizando de anticorpos anti- integrina $\beta 1$, eles conseguiram diminuir a ligação deste receptor o com meio extracelular. Tal fato desencadeou uma mudança na morfologia destas células, fazendo com que as células T4-2 formassem ácinos muito semelhantes aos encontrados na linhagem não tumoral S1. Os fenótipos observados eram reversíveis quando as células eram dissociadas e os anticorpos removidos. Esses resultados apontaram para o fato de que, pelo menos in vitro, que a matriz extracelular e seus receptores poderiam ditar o fenótipo de células epiteliais de mama. Esse novo paradigma fez com que a 
tríade constituída por células mamárias, Matrigel e cultura de células em 3-dimensões fosse amplamente utilizada. A seguir, faremos uma breve abordagem de alguns artigos que se utilizaram deste método para elucidação de mecanismos celulares intrínsecos a biologia da célula mamária.

\subsubsection{COMO SE FORMA UM LÚMEN?}

Como apresentado até agora, em esferóides de células mamárias a formação do lúmen se dá por uma gradativa diminuição do número de células da região medular. Ao final do desenvolvimento, o esferóide assume um arranjo acinar caracterizado por uma única camada de células ao redor de um espaço comum (83-85). Visando entender como a apoptose atuava na formação desta cavidade, Jayanta Debnath e colaboradores começaram a estudar esferóides originados da linhagem não tumoral de mama MCF-10A (para saber mais sobre a origem desta linhagem ver (86)). Neste trabalho (87), eles modularam diferentes genes relacionados à proliferação celular (ciclina D1 e HPV E7) e ao controle da apoptose (proteínas anti apoptótica da família Bcl-2)( B-cell lymphoma 2). Diferentemente do esperado, a inibição da apoptose e o aumento da proliferação celular não foram capazes de impedir a formação do lúmen. Estes autores mostraram então que talvez a morte celular por apoptose não seria a única responsável por essa diminuição do número de células. Fatores como a distância dos componentes da matriz extracelular e a crescente diminuição de nutrientes na região medular, apontavam para o também envolvimento de outra via de sinalização celular: a via autofágica .

A autofagia (macroautofagia) refere-se a qualquer via de degradação celular a qual, por meio de vesículas, envolva a entrega de elementos citoplasmáticos aos lisossomos. Este processo fisiológico, fortemente regulado pelo estresse celular e pela reciclagem de componentes intracelulares, possui importante papel no estudo da biologia da célula tumoral por associar-se a vias regulatórias que permitem ambiguamente tanto a supressão quanto a sobrevivência do tumor (88-90). No contexto descrito até agora, a maior concentração de células em autofagia encontra-se na região central dos esferóides (84, 91, 92). Kenna R. Mills e colaboradores exploraram a relação da morte por apoptose e autofagia também no modelo de esferóide com células MCF-10A (85). Eles descreveram que o receptor TRAIL (tumor necrosis factor related apoptosis inducing ligand) ativava a produção de autofagossomos nas células epiteliais. Ao se bloquear esse receptor juntamente com a apoptose (esta, via superexpressão 
de $\mathrm{BCl}_{\text {-xL }}$ ), eles notaram um aumento de esferóides preenchidos por células, isto é, com a menor formação de cavidades. Além da formação luminal, a autofagia pode também atuar na região central dos esferóides diminuindo a morte celular decorrente por anoikis (93). A literatura vem mostrando que ambas as vias são importantes para a formação do espaço luminal, todavia, a origem da linhagem de mama também pode impossibilitar a organização acinar destas células crescidas em ambiente 3D.

Kenny e colaboradores (72) exploraram em seu trabalho as diferenças tanto morfológicas quanto de expressão gênica em linhagens de mama crescidas em ambiente 3D. Foram analisadas 25 linhagens, as quais poderiam apresentar um fenótipo normal ou um fenótipo tumoral (com diferentes graus de agressividade). Novamente, estes autores confirmaram que a formação de estruturas acinares somente ocorria em células normais. Já nas células tumorais, eles perceberam que quanto maior era o grau de tumorigenicidade, mais fraca era a interação das células no esferóide.

Devido a sua origem, a célula MCF-7 é uma linhagem mamária que apresenta um fenótipo tumoral (94). Esferóides desta célula são bastante utilizados em diversos ensaios que envolvam testes de drogas e radioterapia $(95,96)$. Células MCF-7 quando crescidas em ambiente 3D com Matrigel, formam esferóides que não apresentam estruturas luminais. Esse fato fez com que a alguns autores também utilizassem essa linhagem para melhor compreender esse fato. A modulação de moléculas de adesão (97) como também a utilização de co-cultura com fibroblastos (98), apontam para a possibilidade de reversão de algumas de características tumorais.

Como apresentado até aqui, a pluralidade de fatores associados à formação do lúmen exige, cada vez mais, diferentes abordagens experimentais. Deste modo, quando se analisa com maior detalhe os modelos atualmente envolvidos com esses processos, é clara a prevalência de um tripé metodológico constituído por linhagens mamárias normais, adição de componentes que simulem a membrana basal e tempo de cultura 3D que variem entre 4 e 15 dias. $(91,99$, 100). Tais propriedades podem oferecer uma pressão de seleção a qual ativariam vias de sinalização celulares semelhantes, o que teria como resultante uma convergência de alterações celulares. Assim, o desafio a se transpor neste presente trabalho é o desenvolvimento de um método viável para estudos do desenvolvimento do lúmen, mas que considere 3 apectos: 
- Maior tempo de permanência em cultura 3D (superior a 30 dias)

- A não adição de qualquer suplementação de componentes de membrana basal

- O uso de uma linhagem tumoral

Posterior a essa primeira etapa, atentaremos para as possíveis diferenças morfológicas encontradas ao longo do tempo de cultura 3D, sendo estes resultados comparados com as linhagens crescidas em monocamada. Para tanto, serão avaliados fatores como apoptose, autofagia, proliferação e sobrevivência celular, diferenciação e, por fim, a presença nos esferóides de uma metaloproteinase. Comentaremos um pouco mais a respeito dessas diferentes abordagens a seguir.

\subsection{PROTEÍNAS ANALISADAS}

A morte celular sempre foi bastante estudada em modelos de cultura 3D devido à íntima relação com o microambiente tumoral e com a formação do lúmen. Atuando como principal efetora deste processo, a apoptose será abordada neste presente trabalho por meio de duas frentes. A primeira delas será a quantificação de uma Caspase iniciadora, a Caspase 9. Essa protease específica de cisteína-aspartato, depois de ativada pelo apoptossomo, cliva outras pró-caspases iniciando assim uma seqüência de eventos que culminarão no processo de apoptose $(21,101)$. Em paralelo a isso, avaliaremos as alterações da proteína pró-apoptótica PAR-4 (Prostate Apoptosis Response 4). Esta proteína esta associada tanto à via intrínseca quanto extrínseca da apoptose $(102,103)$. Além de ser pouco expressa em alguns tipos de cânceres (104) ela destaca-se por possuir uma maior fosforilação pela proteína quinase A na sua porção SAC (Selective for Apoptosis in Cancer). Tal característica a torna um alvo seletivo, haja visto que esta região é diferentemente estimulada quando em células normais (105).

Durante o processo de autofagia, diferentes organelas ou proteínas são envolvidas por autofagossomos. Posteriormente a esta etapa, os autofagossomos fundem-se com lisossomos e permitem que os componentes engolfados sejam degradados por hidrolases lisossomais. Dos diferentes genes associados a todo o processo de autofagia, neste presente trabalho focaremos na presença da proteína LC3 (microtubule -associated protein 1 light chain 3) no decorrer do desenvolvimento dos esferóides. A pró-forma dessa proteína é clivada pela ação da proteína Atg4, permitindo assim que LC3 ligue-se a fosfatidiletanolamina (glicofosfolipídio). Ao se observar o fluxo de conversão de LC3B-I (forma citosólica) e LC3B -2 (forma conjugada a 
fosfatidilserina) é possível verificar a atividade dos autofagossomos no interior da célula, e, conseqüentemente, acompanhar a atividade autofágica no processo (106-108).

Em outra abordagem será verificado a alteração de AKT (v-akt murine thymoma viral oncogene) fosforilada. Essa serina/treonina quinase (também conhecida como PKB) está inserida em diferentes vias de sinalização celulares ativadas por fatores de crescimento, citocinas entre outros estímulos celulares (109). Essas vias, quando inserida no contexto da maquinaria tumoral, destacam-se por atuar em componentes do ciclo celular e em proteínas pró-apoptóticas e de pró-sobrevivência $(21,110)$.

A proteína ERK (extracellular signal regulated kinases), na sua forma fosforilada, será outra quinase estudada neste presente trabalho. Esta proteína está relacionada à via de sinalização da oncoproteína Ras (Ras $\rightarrow$ Raf $\rightarrow$ MEK $\rightarrow$ ERK). Após a sua fosforilação, ERK migra do citoplasma para o núcleo das células, podendo ativar diversos fatores de transcrição bem como permitir reconfigurações de proteínas associadas à cromatina. Estimulando a maquinaria de síntese protéica, essa cascata de eventos pode estimular a expressão de importantes genes reguladores de crescimento como, por exemplo, ciclina D1. $(21,111,112)$.

Também será feita uma abordagem voltada para interação célula-célula. Para tanto, será analisada a proteína E-caderina. Localizada em sítios de adesão intercelulares (denominados de junções aderentes) essas proteínas possuem interação com componentes do citoesqueleto, principalmente os microfilamentos de actina. A expressão desta proteína está intimamente conectada com o grau de epitelialidade, atuando assim como um importante supressor de tumor $(113,114)$.

Por fim, a última proteína que será analisada é ADAMTS-1 ( $\boldsymbol{a}$ disintegrin and metalloprotease with thrombospondin motifs-1). Essa enzima possui um importante papel no renovação de proteínas de matriz extracelular em vários tecidos. A alteração em sua regulação está associada a diversos processos patológicos, inflamação, desenvolvimento e progressão do câncer $(115,116)$

\subsection{CONSIDERAÇÕES FINAIS}

Há quase 100 anos atrás, decorrente de uma pequena intervenção feita por Carrel em suas culturas, iniciavam-se os estudos com cultura de células em 3D. Desde então, o crescente 
uso e a diversidade de aplicações desta técnica, possibilitaram um olhar mais intimista ao que se refere às interações célula-célula e com o ambiente. Hoje, a cultura de células em 3D assume importante papel nos estudos relacionados à morfogênese luminal, permitindo acompanhar in vitro fatores regulatórios deste processo. Desta forma, o desenvolvimento de novos modelos de cultura de células em 3D são cada vez mais importantes devido a permitir uma melhor compreensão da formação do lúmen. É neste contexto que se insere este presente trabalho, o qual objetivo será abordado a seguir. 


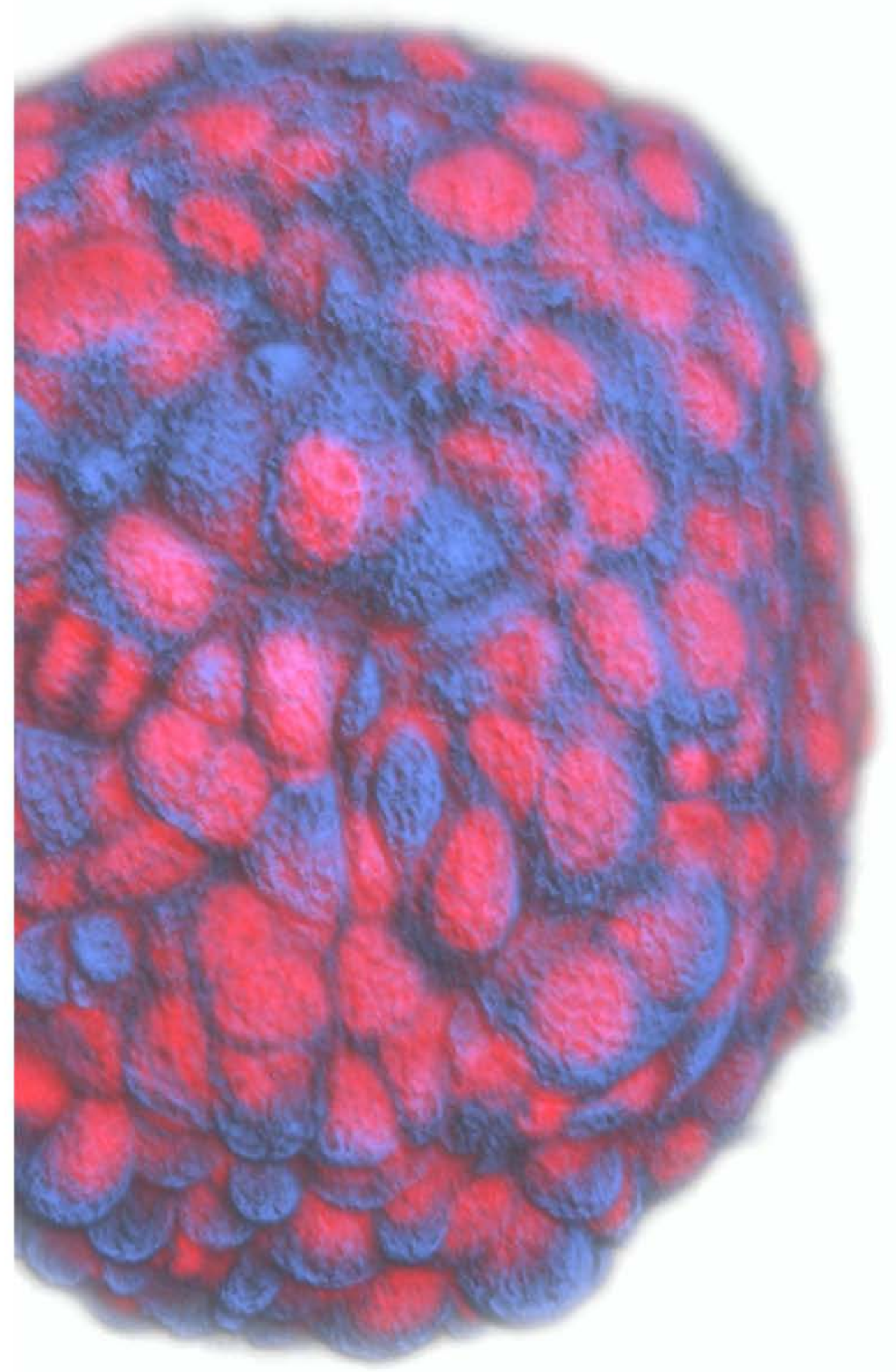

2_OBJETIVOS 
O objetivo deste trabalho foi estudar aspectos morfofisiológicos de células MCF-7 na ausência de elementos exógenos de matriz extracelular, para avaliar seu possível uso como modelo tumoral. Deste modo, o principal foco foi avaliar a viabilidade de se manter estas culturas por longos períodos em cultura 3D (superiores a trinta dias) e analisar o comportamento destas células em um ambiente de maior interação célula-célula, avaliando importantes aspectos como diferenciação e morte celular. Dentro deste contexto, serão analisadas a expressão de diferentes proteínas durante o período de cultura em 3D as quais terão seus resultados comparados com células MCF-7 crescidas em monocamada. 


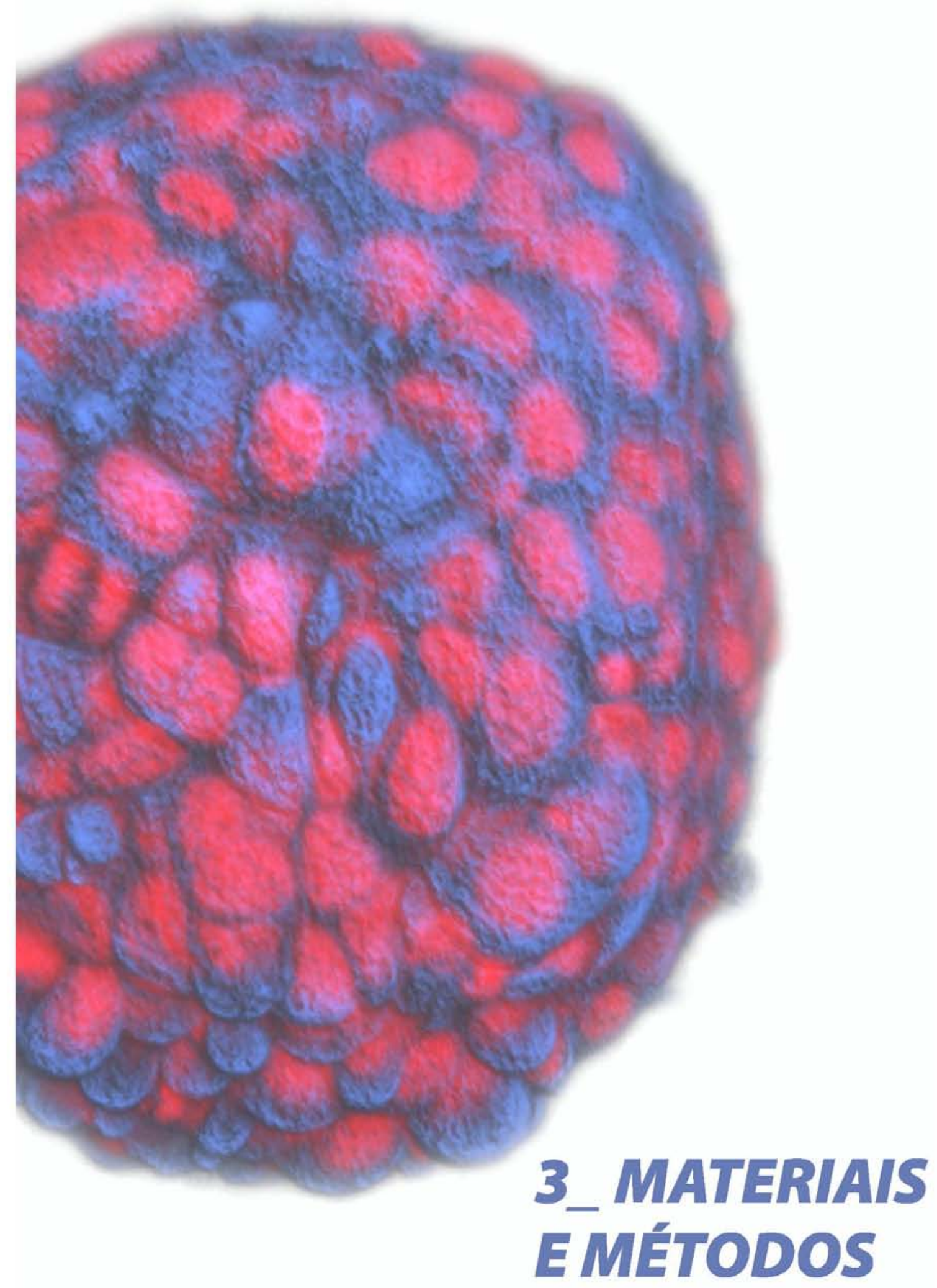




\subsection{MANUTENÇÃO DA LINHAGEM E A CULTURA DE CÉLULAS EM 3 DIMENSÕES}

Foi utilizada a linhagem celular MCF-7 (94) derivada de efusão pleural de adenocarcinoma mamário. Esta linhagem foi obtida da ATCC ${ }^{\circledR}$ (American Type Culture Collection) (Manassas, VA, Estados Unidos da América) através do Banco de Células do Rio de Janeiro (catálogo $n^{\circ}$ CR119). Acondicionada em ampolas de congelamento, as células foram mantidas em nitrogênio líquido.

Após descongelamento e posterior retirada da solução de congelamento, as células foram transferidas para frascos de cultura de tecidos (com área de $25 \mathrm{~cm}^{2}$ ) contendo meio de cultura DMEM (meio de cultura de Eagle modificado por Dulbecco) suplementado com $10 \%$ de soro fetal bovino. A linhagem então foi mantida em uma incubadora com uma atmosfera contendo $5 \%$ de $\mathrm{CO}_{2}$ e uma temperatura de $37{ }^{\circ} \mathrm{C}$. As células arranjadas em monocamada foram submetidas a uma dissociação enzimática com uma solução de tripsina 0,2 \% +EDTA 0,02 \% (ácido etilenodiamino tetra-acético).

Após a neutralização da atividade desta enzima (utilizando o mesmo meio de cultura) e posterior retirada da solução de tripsina-EDTA utilizando PBSA (solução de tampão fosfato de sódio sem cálcio e magnésio), as células em suspensão foram contadas utilizando o citômetro de fluxo Guava easycycle mini (Milipore Biosciences Tessicula, CA, Estados Unidos da América). Padronizou-se o uso de uma densidade de células de 80 células/ $\mu \mathrm{L}$ de meio de cultura, para a cultura em 3 dimensões.

Com o objetivo de retirar possíveis fragmentos de poliestireno, as placas de Petri (com dimensões de 60×15 mm) foram previamente lavadas com PBSA. Nesse momento foi checado também a presença de hidrofobicidade na superfície das placas (Figura 7A) característica importante para dificultar a adesão celular.

A técnica utilizada para a formação dos esferóides foi a de cultura celular em sobreposição líquida (liquid overlay) (Figura 7C), a qual consiste em não permitir a adesão na superfície do recipiente. Foram colocados $5 \mathrm{~mL}$ de meio de cultura em cada placa, estas contendo $4 \times 10^{5}$ células. As placas com os esferóides foram mantidas na incubadora nas mesmas condições descritas previamente para garrafas de cultivo. 
A cada 3 dias, todo o conteúdo das placas foi retirado e colocado em tubos de centrifugação $(15 \mathrm{ml})$. Por gravidade, as células da linhagem MCF-7 (agora arranjada como esferóides) se concentraram no fundo destes tubos (Figura 7B). Desta forma é possível a retirada do meio de cultura, lavagem com PBSA e posterior adição de novo meio de cultura. 0 tempo de crescimento dos esferóides estendeu-se até 155 dias, entretanto, em alguns experimentos foram selecionadas datas específicas, sendo estas 7, 30 e 50 dias de cultura. Todos os resultados obtidos na cultura em 3 dimensões foram comparados com os resultados das células MCF-7 crescidas em monocamada.

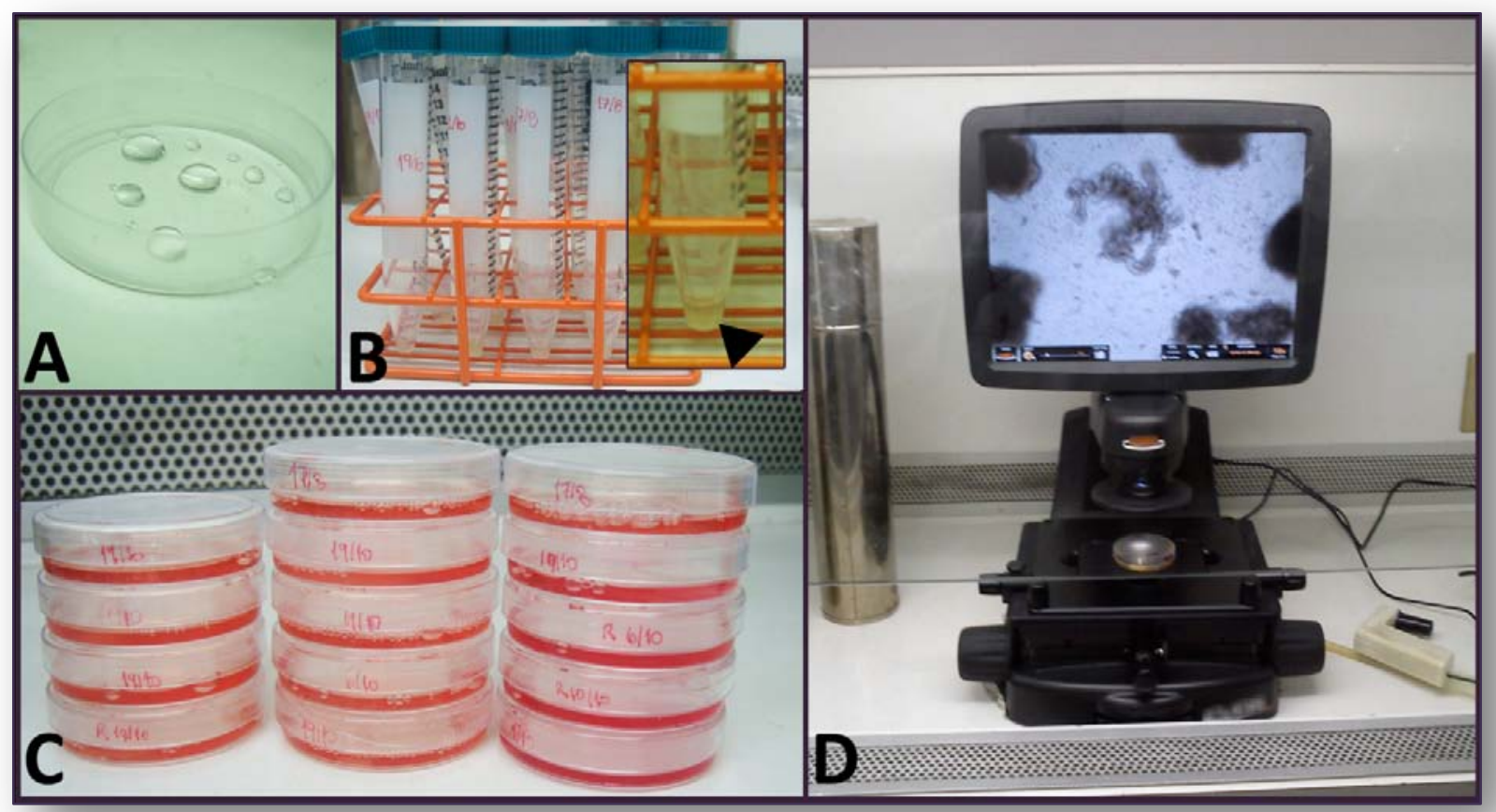

Figura 7 - Fotografias de alguns procedimentos utilizados neste trabalho, sendo eles: teste de hidrofobicidade da superfície de placas de acrílico (A), coleta dos esferóides em diferentes tempos de cultura por meio de decantação ( $B$ e em detalhe o fundo de tubo de centrífuga contendo esferóides), placas de Petri contendo os esferóides em meio de cultura (C) e a utilização de microscopia para a coleta dos esferóides diferenciados no interior do fluxo laminar (D). 


\subsection{MÉTODOS PARA A DESCRIÇÃO DA MORFOLOGIA DOS ESFERÓIDES}

\subsubsection{Microscopia de Luz}

Imagens digitais foram obtidas em todas as fases do desenvolvimento dos esferóides utilizando-se tanto de microscopia de contraste de fase quanto de campo claro. Para isso, as placas de Petri contendo os esferóides bem como as garrafas de cultura contendo as células em monocamada, foram observadas ao microscópio invertido digital da marca EVOS ${ }^{\circledR}$ AME-3302 (Aeleusden, Holanda).

\subsubsection{Microscopia de fluorescência e confocal de varredura a laser}

\section{Preparo das células}

O crescimento em monocamada das células MCF-7 se deu no interior de placas de cultivo de celular sob lamínulas de vidro imersas em meio de cultura DMEM. Após a lavagem destas células em solução de PBSA (repetida 3 vezes em todos os procedimentos) as células foram fixadas com formaldeído 3,7\% em PBSA por um período de 30 minutos. Já os esferóides analisados foram coletados em diferentes tempos de cultura (os quais se estenderam por até 155 dias). Para evitar fragmentação das estruturas, todos os esferóides foram separados de qualquer solução pelo processo de decantação (Figura 5B). Retirado o meio de cultura, os esferóides passaram pelas mesmas etapas de lavagem e fixação descritas para monocamada.

Posteriormente às lavagens em PBSA, as células foram permeabilizadas com uma solução de Triton-x 100 0,5\% por 30 minutos para monocamada e 1 hora (com agitação) para os esferóides. Novamente lavados, o material foi agora submetido a uma solução de bloqueio com albumina a 3\% em PBSA. Depois de 1 hora células foram então lavadas novamente com PBSA e seguiram para as marcações fluorescentes.

Para não tornar o texto repetitivo, optamos por suprimir os detalhes descritos acima em todos os procedimentos apresentados neste trabalho. Assim, por exemplo, ao se ler lavagem em PBSA no texto, subentende-se que foram 3 lavagens. 


\section{Imunofluorescência}

Os anticorpos primários (Tabela 1) foram utilizados na diluição recomendada pelos fabricantes. O volume colocado em contato com as células foi de $10 \mu \mathrm{l}$ para a monocamada e $30 \mu \mathrm{l}$ para esferóides. Para espraiar a solução sobre a superfície plana da lamínula foi recortado um quadrado de parafilm e colocado sob a solução. Já nos esferóides, a exposição aos anticorpos primários ocorreu em tubos de Eppendorf de 1,5 ml. Para evitar a evaporação, as lamínulas com parafilm foram colocadas em recipientes com papel molhado (câmara úmida) hermeticamente fechado. As células foram incubadas ao redor de 12 horas (entre um dia e outro) sendo que, nos esferóides estas permaneceram em constante agitação.

Tabela 1 - Anticorpos utilizados nos experimentos de imunofluorescência.

\begin{tabular}{|c|c|}
\hline Anticorpo /Empresa/Breve Descrição & Concentração utilizada \\
\hline $\begin{array}{l}\text { Anti -LC3B-policlonal (coelho) (Abcam }{ }^{\circledR} \text { ab51520) (Cambridge, } \\
\text { MA, Estados Unidos da América) } \\
\text {-Marcador de autofagosso }\end{array}$ & $1: 150$ \\
\hline $\begin{array}{l}\text { Anti- } \beta \text { tubulina (camundongo) (Sigma }{ }^{\circledR} \text { T5293) (St. Louis, MO, } \\
\text { Estados Unidos da América) } \\
\text {-Componente dos microtúbulos }\end{array}$ & $1: 250$ \\
\hline $\begin{array}{l}\text { Anti- } \alpha \text { tubulina (camundongo) (Sigma }{ }^{\circledR} \mathrm{T} 5168 \text { ) } \\
\text {-Componente dos microtúbulos }\end{array}$ & 1: 250 \\
\hline $\begin{array}{l}\text { Anti-ADAMTS-1 (coelho) (Abcam }{ }^{\circledR} \text { ab28284-100) } \\
\text {-Metaloproteínase }\end{array}$ & $1: 200$ \\
\hline $\begin{array}{l}\text { Anti-laminina (coelho) }\left(\text { Sigma }^{\circledR} \text { L9393) }\right. \\
\text {-Constituinte da Lamina basal }\end{array}$ & $1: 200$ \\
\hline $\begin{array}{l}\text { Anti-5-bromo-2-deoxiuridina, BrdU (camundongo) } \\
\text { 8434) } \\
\text {-Análogo da timidina, incorporado na síntese do DNA }\end{array}$ & $1: 100$ \\
\hline $\begin{array}{l}\text { M30 conjugado a isotiocianato de fluoresceína (Cyto DEATH } \\
\text { Roche }{ }^{\circledR} \text { ) (Indianapolis, IN, Estados Unidos da América) } \\
\text {-Se liga à citoqueratina } 18 \text { clivada, indicando apoptose }\end{array}$ & $1: 50$ \\
\hline $\begin{array}{l}\text { Anti-p-Akt1/2/3 (Thr 308) (coelho) (Santa } \text { Cruz }^{\circledR} \text {-Sc 16646-R) } \\
\text { (Santa Cruz, CA, Estados Unidos da America) } \\
\text {-Importante componente de diversas vias de sinalização }\end{array}$ & $1: 250$ \\
\hline $\begin{array}{l}\text { Anti-lgG de camundongo conjugado a isotiocianato de } \\
\text { fluoresceína (Sigma }{ }^{\circledR} \mathrm{F9137)} \\
\text {-Anticorpo secundário necessário para evidenciar por } \\
\text { fluorescência a proteína alvo (anticorpo primário) }\end{array}$ & $1: 200$ \\
\hline
\end{tabular}


Após nova lavagem com PBSA, os procedimentos apresentados no item anterior se repetem para a aplicação dos anticorpos secundários. Todavia, deve se atentar que devido a conjugação com fluoróforos nestes anticorpos, o cuidado com a exposição à luz deve ser intensificado. Outra diferença que deve ser considerada se refere ao tempo de incubação, o qual é suficiente ao redor de 3 horas para monocamada. Nos esferóides, entretanto, recomenda-se estender essa incubação com o anticorpo secundário por 6 horas.

O material processado para microscopia de fluorescência foi preparado para ser observado utilizado 3 diferentes canais ao microscópio confocal de varredura a laser. Um canal sempre foi reservado para a marcação nuclear sendo assim, quando necessário, em algumas preparações foram utilizadas 2 imuno-marcações (sendo uma com anticorpo secundário antiIgG de coelho e a outra anti-IgG de camundongo). Outra opção foi à adição de um corante fluorescente em paralelo com a imunomarcação.

Desta maneira, após o término da imunomarcação, o material foi novamente lavado com PBSA e seguindo para a coloração com corantes fluorescentes.

\section{Corantes fluorescentes}

Para a deteç̧ão dos microfilamentos de actina foi utilizada uma solução contendo faloidina conjugada a FITC (isoticianato de fluorceina) (Sigma ${ }^{\circledR}$ ) ou a Alexa fluor 633 (Invitrogen ${ }^{\circledR}$ ) na concentração de 7,5 $\mu \mathrm{M}$ em PBSA. As células ficaram em contato com essas substâncias por um período de 40 minutos para monocamada e até 4 horas para esferóides, sendo posteriormente lavados com PBSA .

As marcações nucleares de todas as lâminas utilizadas neste trabalho foram feitas por meio de um corante específico para ácidos nucléicos, o iodeto de propídeo, na concentração de $10 \mu \mathrm{g} / \mathrm{mL}\left(\right.$ Sigma $\left.^{\circledR}\right)$. Devido ao interesse somente pelo DNA, as células ficaram em contato com uma solução de RNAase $(10 \mathrm{mg} / \mathrm{mL})$ por uma hora. Após isso as células foram lavadas em PBSA.

\section{Solução protetora de fluorescência e a montagem das lâminas}

Efetuada a última lavagem com PBSA, os esferóides foram mantidos ao fundo do tubo de Eppendorf ${ }^{\circledR}$. Foram adicionados um volume de $20 \mu \mathrm{l}$ de solução protetora de fluorescência (anti-fading-Vectashield ${ }^{\circledR}$ Burlingame, CA, Estados Unidos da América) juntamente com $3 \mu \mathrm{l}$ de 
solução de iodeto de propídeo. Com o auxílio de uma tesoura, foi cortada a ponta da ponteira de uma micropipeta (aumentando o diâmetro da entrada) e por sucção os esferóides foram retirados e colocados sob uma lâmina de vidro. Já na monocamada foi adicionado $8 \mu$ le solução protetora de fluorescência e $2 \mu$ le solução de iodeto de propídeo, sendo este conjunto colocado sob uma lâmina de vidro. Em ambos processos, as lamínulas de vidro foram vedadas com esmalte de unha. Para evitar um achatamento dos esferóides entre as lâminas e as lamínulas foram colocados 4 pontos de esmalte nas extremidades das superfícies voltadas para o material, aumentando assim a altura. As lâminas foram acondicionadas em ambiente escuro e mantidas à $-20^{\circ} \mathrm{C}$.

\section{Análise do material ao microscópio confocal de varredura a laser}

As células foram analisadas ao microscópio confocal de varredura a laser (Zeiss LSM 510) sendo as imagens fluorescentes adquiridas utilizando-se de laseres de Argônio (458, 488, e 514 nm), Hélio-Neônio1 (543 nm) e Hélio-Neônio2 (633 nm). As fatias ópticas foram obtidas em intervalos adequados no eixo Z, entre 0,5 e $1 \mu \mathrm{m}$. Diferentes módulos do software LSM 510 3D (Carl Zeiss ${ }^{\circledR}$ Jena, Thuringia, Alemanha) foram utilizados na análise confocal, os quais incluem: projeções das fatias, cortes ortogonais e animações. Algumas reconstruções e animações foram feitas no software IMARIS 7.1 (Bitplane ${ }^{\circledR}$ Zurique, Canton de Zurique, Suíça).

\subsubsection{Microscopia eletrônica}

\section{Microscopia eletrônica de transmissão}

Após a retirada do meio de cultura, os esferóides foram lavados com uma solução de tampão cacodilato de sódio $0,1 \mathrm{M} \mathrm{pH} \mathrm{7,2} \mathrm{e} \mathrm{fixados} \mathrm{com} \mathrm{a} \mathrm{solução} \mathrm{de} \mathrm{glutaraldeído} 2,5 \%$ com formaldeído $2 \%$ no mesmo tampão adaptado de (117).

Após 2 horas a temperatura de bancada (ao redor de $25^{\circ} \mathrm{C}$ ), o fixador foi retirado e o material passou por 3 banhos de 5 minutos em tampão cacodilato de sódio. Após este processo iniciou-se a pós-fixação com uma solução de tetróxido de ósmio a $1 \%$ em tampão cacodilato de sódio. Os esferóides foram lavados em água destilada e seguiram para uma gradual desidratação etílica de 15 minutos cada banho (50, 70, 80, 90 e 2x 100\% etanol). 
Na etapa final da desidratação o material ficou imerso em óxido de propileno durante 10 minutos ( 2 banhos de 5 minutos), seguindo para um banho de uma mistura de resina Epon ${ }^{\circledR}$ (Electron Microscopy Science, PA, Estados unidos da América) mais óxido de propileno (1:1) durante 5 horas. A mistura foi substituída por resina Epon ${ }^{\circledR}$ pura, permanecendo as células nesta solução por mais 5 horas. A inclusão das células foi feita em formas de silicone preenchidas com a mesma resina, sendo esta polimerizada após 72 horas em estufa a $65^{\circ} \mathrm{C}$.

Após o desbaste dos blocos de resina, foram feitos cortes em ultramicrótomo com espessura de $7 \mu \mathrm{m}$, sendo estes montados em lâmina de vidro, corados com azul de toluidina e visualizados ao microscópio de luz. Escolhida a região de interesse no bloco, foram feitos cortes na espessura de 70 a $90 \mathrm{~nm}$, sendo posteriormente colocados em telas de cobre (200 mesh). 0 material foi contrastado em uma solução de acetato de uranila a $4 \%$ por 30 minutos, posteriormente lavados em água e colocados em uma solução de citrato de chumbo a $10 \%$. Após serem novamente lavados, retirou-se o excesso de água destilada e as telas de cobre foram acondicionadas em um porta-telas e mantidas em ambiente resfriado. $\mathrm{O}$ material foi analisado e fotografado ao microscópio eletrônico de transmissão Jeol ${ }^{\circledR}$ (Queensland, Brisbane, Austrália) 1010 (80 kV).

\section{Microscopia eletrônica de varredura}

As células foram submetidas aos mesmos processos de fixação e desidratação descritos acima (microscopia eletrônica de transmissão). O material também passou por uma desidratação etílica, sendo que na etapa final os esferóides passaram por 2 banhos com acetona pura. Para o término da desidratação o material foi submetido ao aparelho de ponto crítico ou a banhos em solução de hexametildisilazane. As células foram aderidas a cilindros de metal sendo este material posteriormente metalizado em aparelho de pulverização catódica. 0 cilindro contendo o material foi então analisado e fotografado ao microscópio eletrônico de varredura Jeol ${ }^{\circledR} 6100(30 \mathrm{kV})$. 


\subsection{INCORPORAÇÃO DO 5-BROMO-2-DESOXIURIDINA (BRDU)}

O composto BrdU (concentração de 0,3 mM) foi adicionado ao meio de cultura utilizado ficando em contato com as células por um período de 1 hora. Depois desta incorporação o material foi fixado com uma solução de etanol:ácido acético (3:1) por 20 minutos para monocamada e 40 minutos para esferóides. Lavados com PBSA, as células passaram por um processo de permeabilização com Triton. Após lavagem com PBSA, o DNA foi hidrolisado com $\mathrm{HCl} 2 \mathrm{~N}$ por 30 minutos sendo posteriormente lavadas. Finalmente as células foram imunomarcadas com anti-BrdU e os núcleos corados com iodeto de propídeo.

\subsection{QUANTIFICAÇÃO DO DNA POR CITÔMETRIA DE FLUXO}

As células MCF-7 crescidas em monocamada e em cultura 3D passaram por um processo de dissociação enzimática por tripsina com o objetivo de retirar estas células das garrafas de cultivo como também dissociar os esferóides com diferentes tempos de cultura. Após a neutralização da tripsina com meio de cultura as células foram transferidas para tubos de centrifugação de $15 \mathrm{~mL}$, sendo a suspensão centrifugada por 5 minutos a $300 \mathrm{G}$. O sobrenadante foi descartado e o precipitado formado foi ressuspenso em $1 \mathrm{~mL}$ de PBSA. Foi então acrescentado $3 \mathrm{~mL}$ de metanol $100 \%$ à $4{ }^{\circ} \mathrm{C}$ e, após cuidadosa agitação, os tubos foram colocados no gelo por 1 hora. Novamente centrifugados (nas mesmas condições descritas anteriormente) e retirado o sobrenadante, as células foram novamente lavadas com $1 \mathrm{~mL}$ de PBSA. Após nova centrifugação e retirada do sobrenadante, o precipitado foi ressuspenso em uma solução contendo $200 \mu \mathrm{L}$ de PBSA, $20 \mu \mathrm{L}$ de RNAase $(10 \mathrm{mg} / \mathrm{mL})$ e $20 \mu \mathrm{L}$ de iodeto de propídeo $(10 \mu \mathrm{g} / \mathrm{mL})$. A solução foi cuidadosamente agitada e deixada no gelo por 1 hora.

Para a análise do ciclo celular, o DNA de cada amostra foi quantificado pelo citômetro de fluxo Guava easycycle mini $\left(\mathrm{GE}^{\circledR}\right)$, sendo cada experimento obtido em triplicata. 


\subsection{DETECÇÃO DE MORTE CELULAR}

3.5.1 Marcação para M30

Após serem fixadas e permeabilizadas (ver item preparo das células), as células foram tratadas com RNaase por 30 minutos $(10 \mathrm{mg} / \mathrm{mL})$. Lavadas novamente com PBSA, as células foram então expostas ao anticorpo monoclonal M30 conjugado a FITC (CytoDEATH-Roche ${ }^{\circledR}$ ), o qual se liga a fragmentos de citoqueratina 18. Este material foi mantido por 12 horas (entre um dia e outro) à temperatura ambiente em câmara úmida e no escuro. Após lavagem em PBSA, os núcleos foram corados com iodeto de propídeo.

\subsubsection{ENSAIO DE CASPASE 9}

Após o processo de dissociação enzimática por tripsina tanto nas células em monocamada quanto nos esferóides, estes foram separados $100 \mu$ l de cada amostra na concentração de $1 \times 10^{5}$ células $/ \mathrm{mL}$. Após isso, adicionou-se $10 \mu \mathrm{l}$ de Caspase Reagent working solution sendo as células então encubadas por 1 hora a $37{ }^{\circ} \mathrm{C}$. Posteriormente a esse processo foram adicionados $100 \mu \mathrm{l}$ de $1 x$ Apoptosis Wash Buffer às amostras que seguiram para centrifugação a $300 \mathrm{G}$ por 7 minutos. Após o descarte do sobrenadante, as células foram ressuspendidas em $200 \mu \mathrm{l}$ de Caspase 7-AAD Working Solution diluído a 1:40 com 1x Apoptosis Wash Buffer. Após incubação de 10 minutos à temperatura ambiente e no escuro, as amostras foram lidas em citômetro de fluxo Guava easycycle mini $\left(\mathrm{GE}^{\circledR}\right)$, sendo cada experimento obtido em triplicata. Todos os reagentes descritos neste item são parte do Guava ${ }^{\circledR}$ Caspase Kit (Millipore ${ }^{\circledR}$ ).

As populações separadas por esses reagentes podem ser separadas em:

-Células viáveis: esta população celular foi caracterizada pela integridade da membrana (comprovado pela não penetração do corante 7-aminoactinomicina-7-AAD) e ausência de marcação para o corante específico para Caspase 9.

-Células necróticas: como mostrado previamente na microscopia eletrônica de transmissão, a integridade da membrana das células que estão passando por esse processo é bastante alterada. Tal característica permite a entrada do corante 7-AAD, ao mesmo tempo que estas células se mostram negativas ao corante de Caspase 9. 
-Células em apoptose: estas células possuem como marcador principal a positividade para Caspase 9. A não integridade da membrana faz com que sejam selecionados dois grupos; apoptose inicial- negativa para 7-AAD e apoptose final-positiva para o mesmo corante. Neste trabalho optamos somar esses valores.

\subsection{ANÁLISE DA EXPRESSÃO DE PROTEÍNAS}

As células em monocamada e crescidas em cultura 3D foram homogeneizadas em tampão RIPA ( $\mathrm{NaCl} 150$ mM, NP-40 1\%, ácido deoxicolato de sódio 0,5\% em Tris 50 mM-HCl em $\mathrm{pH} 7,5)$ contendo inibidores de proteases na concentração final de $2 \%\left(\right.$ Sigma $\left.^{\circledR}\right)$. Após centrifugação a $12000 \mathrm{G}$ por 10 minutos o sobrenadante foi coletado e alíquotas foram separadas para a quantificação pelo método de BCA (ácido bicincrônico). A leitura da absorbância foi realizada por ELISA utilizando filtro de $595 \mathrm{~nm}$.

As amostras foram diluídas em tampão de amostra 4x (Tris 0,5 M, pH 6,8, glicerol SDS $10 \%$, azul de bromofenol $1 \%$ e betamercaptoetanal $1 \%$ em água milliQ) e fervidas por 5 minutos (100 C). O fracionamento das proteínas foi realizado em gel de poliacrilamida $10 \%$ com SDS (dodecil sulfato de sódio) (2 horas a 100V). Em cada poço foram colocados $30 \mu \mathrm{g}$ de proteínas totais. O padrão de peso molecular utilizado foi Precision Plus Standards-Dual Core Bio-Rad.

A transferência para a membrana de PVDF (fluoreto de polivinilideno) (Amersham GE ${ }^{\circledR}$ Uppsala, Uppsala, Suíça) foi realizada por 2 horas a $200 \mathrm{~mA}$ em tampão (Tris 0,025M, glicina 0,192M e metanol a $20 \%$ em água destilada). Após transferência das proteínas a membrana foi corada em solução de Ponceau 0,5\% por 3 minutos para verificar a eficiência da transferência. Em seguida, a membrana foi lavada 3 vezes em TBS a 0,02 M (10 minutos cada lavagem). 0 bloqueio foi realizado com TBS a 0,02 M contendo leite em pó desnatado a 5\% e tween a 0,05\% por uma hora à temperatura ambiente sob agitação.

Os anticorpos primários (ver Tabela 2) foram diluídos em solução de bloqueio sendo a membrana incubada por 12 horas (entre um dia e outro) a $4{ }^{\circ} \mathrm{C}$ sob agitação. Após sucessivas lavagens com TBS e TTBS, a membrana foi incubada com anticorpos secundários (1:5000) (Kit $\mathrm{ECL}$, Amersham $\mathrm{GE}^{\circledR}$ ), lavado novamente e revelado por quimioluminescência (ECL, Amersham 
$\mathrm{GE}^{\circledR}$ ) conforme especificações do fabricante. Os resultados foram registrados em filme Hyperfilm (Amershan GE ${ }^{\circledR}$ ).

Para o controle da concentração de proteínas carregadas por poço do gel foram utilizados os anticorpos anti- $\beta$-tubulina e anti- $\beta$-actina.

Tabela 2-Anticorpos utilizados nos experimentos de western blotting.

\begin{tabular}{|c|c|}
\hline Anticorpo /Empresa/Breve Descrição & Concentração utilizada \\
\hline Anti -LC3B-policlonal (coelho) (Abcam ${ }^{\circledR}$ ab51520) & 1:1000 \\
\hline \multicolumn{2}{|l|}{-Marcador de autofagosso } \\
\hline Anti- $\beta$ tubulina (camundongo) (Sigma ${ }^{\circledR}$ T5293) & 1:1000 \\
\hline \multicolumn{2}{|l|}{-Componente dos microtúbulos (controle do carregamento) } \\
\hline Anti $\beta$ actina (camundongo) (Sigma ${ }^{\circledR} \mathrm{A} 2228$ ) & 1:1000 \\
\hline \multicolumn{2}{|c|}{-Componente dos microfilamentos de actina (controle do carregamento) } \\
\hline Anti-PAR 4 (coelho) (Abcam ${ }^{\circledR}$ ab49155-100) & 1:1000 \\
\hline \multicolumn{2}{|l|}{-Morte celular } \\
\hline Anti-ADAMTS-1 (coelho) (Abcam ${ }^{\circledR}$ ab28284-100) & 1:1000 \\
\hline \multicolumn{2}{|l|}{-Metaloproteínase } \\
\hline Anti-p-ERK (Tyr 204) (coelho) (Santa Cruz ${ }^{\circledR}$ Sc-7976-R) & 1:500 \\
\hline \multicolumn{2}{|l|}{-Importante componente das vias de transdução de sinal } \\
\hline Anti-p-Akt1/2/3 (Thr 308) (coelho) (Santa Cruz ${ }^{\circledR}$-Sc 16646-R) & $1: 500$ \\
\hline -Importante componente de diversas vias de sinalização & \\
\hline
\end{tabular}

\subsection{SELEÇÃO DOS ESFERÓIDES DIFERENCIADOS}

Os esferóides foram coletados aos 50 dias de cultivo em cultura 3D utilizado de uma micropipeta e com auxílio do microscópio invertido digital da marca EVOS ${ }^{\circledR}$ AME-3302 (Figura 7D). Toda a coleta destes esferóides diferenciados ocorreu dentro do fluxo laminar. Como critério de seleção padronizou-se a coleta de esferóides que apresentassem um arranjo alongado sem a presença de grandes massas esféricas (essas predominantes aos 30 dias de cultura, mas também presente em menor número aos 50 dias) (Figura 13). 
Esses esferóides foram colocados para crescer diretamente em garrafas de cultivo de tecidos ou após dissociação pela tripsina. As células foram mantidas nestas condições (2D) até que estas obtivessem confluência. Subcultivadas mais uma vez, o número de células foi expandido e após dissociação pela tripsina, as células foram mantidas em cultura 3D nas condições previamente descritas.

\subsection{ANÁLISE DO PERFIL DE EXPRESSÃO DE RNAm DE E-CADERINA}

Os RNAs foram extraídos utilizando o kit de extração ChargeSwitch total RNA Cell Kit (Invitrogen ${ }^{\circledR}$ ) e quantificados em um NanoDrop ND1000 Spectrophotometer.

Para a análise do perfil de expressão foram realizadas reações de RT-PCR em tempo real em um aparelho da Corbett Research modelo Rotor Gene 6000 real-time cycler e o kit AgPathID One-Step RT-PCR kit (Applied Biosystems). As condições dos PCRs em tempo real foram $45^{\circ} \mathrm{C}$ por $10 \mathrm{~min} ; 95^{\circ} \mathrm{C}$ por $10 \mathrm{~min}, 40$ ciclos $\left[95^{\circ} \mathrm{C}\right.$ por $15 \mathrm{seg} ; 55^{\circ} \mathrm{C}$ por $20 \mathrm{seg} ; 72^{\circ} \mathrm{C}$ por $40 \mathrm{seg}$ ], seguindo então o melt. As temperaturas de anelamento foram determinadas especificamente para cada par de primers.

\section{Primers utilizados}

qE_Cadherin_left

TACCTGCTCACGTCAAATGC

qE_Cadherin_right

AAAGTGATGACCTCCCATGC

\subsection{ANÁLISE ESTATÍSTICA}

A análise estatística dos dados obtidos foi feita pelo teste $\chi^{2}$ de tendência, tomando-se como referência o grupo crescido arranjado em monocamada. Em todas as análises o nível de significância foi menor que $5 \%(P<0,05)$. 


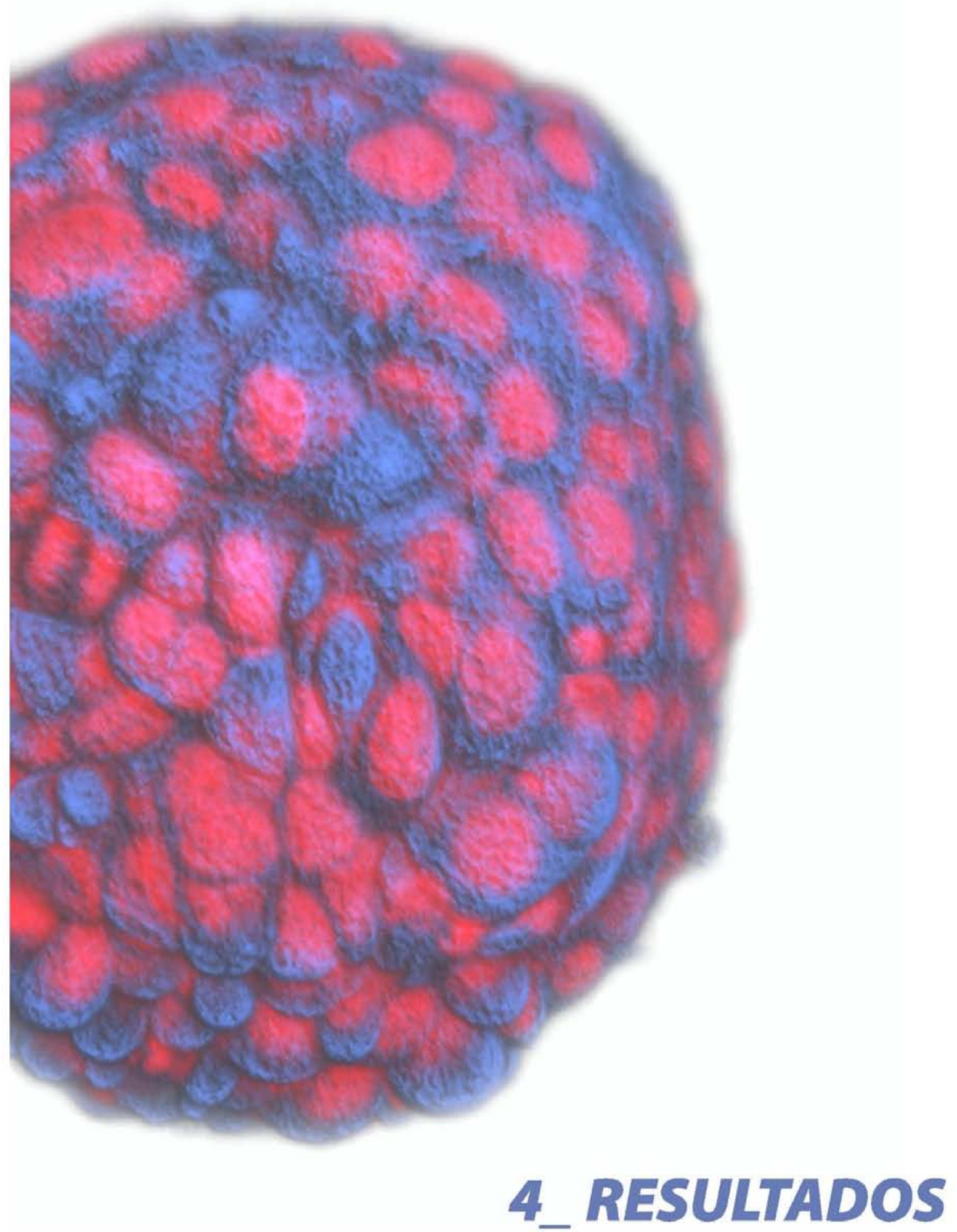




\subsection{DESENVOLVENDO O MÉTODO E ESCOLHA DA LINHAGEM}

Como já apresentado, neste trabalho nossa análise limitou-se a linhagens celulares comerciais de mama em uso no nosso laboratório. Assim, foram utilizamos linhagens que variaram desde um fenótipo considerado normal (MCF-10A) bem como 4 linhagens tumorais com diferentes graus de agressividade (MCF-7, T47-D, MDA-MB 231 e Hs578T). Em nosso delineamento experimental, priorizamos o uso de células que se adaptassem ao cultivo celular em 3D (modo de imersão em líquido), que formassem esferóides estáveis e que a produção destes fosse facilmente reprodutível.

A linhagem MCF-10A (Figura 8C e D), bastante utilizada em culturas 3D, apresentou problemas em relação à formação de esferóides. Ao serem colocadas em ambiente 3D estas células iniciaram um forte processo de anoikis (morte celular decorrente da não adesão). O seu uso em cultura 3D esteve sempre vinculado a adição de componentes de lâmina basal ao meio de cultura, todavia, esse método de cultivo não era o objetivo do presente estudo.

Por outro lado, quando analisamos as linhagens tumorais, notamos que todas formaram esferóides quando submetidas ao nosso protocolo (Figura 8A, B e E). A diferença entre essas linhagens foi que o número de esferóides obtidos com as células mais agressivas (Hs578T e MDA-MB 231) foi relativamente menor quando comparado com as linhagens menos agressivas (MCF-7 e T47-D). Tal fato fez com que nossa análise se concentrasse nas linhagens MCF-7 e T47-D.

Desta forma, por um período de aproximadamente 30 dias, foram comparados os resultados obtidos com as duas linhagens crescidas em monocamada e crescidas em 3D. Em decorrência a esses estudos iniciais foi observado que a linhagem MCF-7 melhor se adequaria as nossas análises. Os motivos que levaram a essa escolha serão mostrados a seguir. 


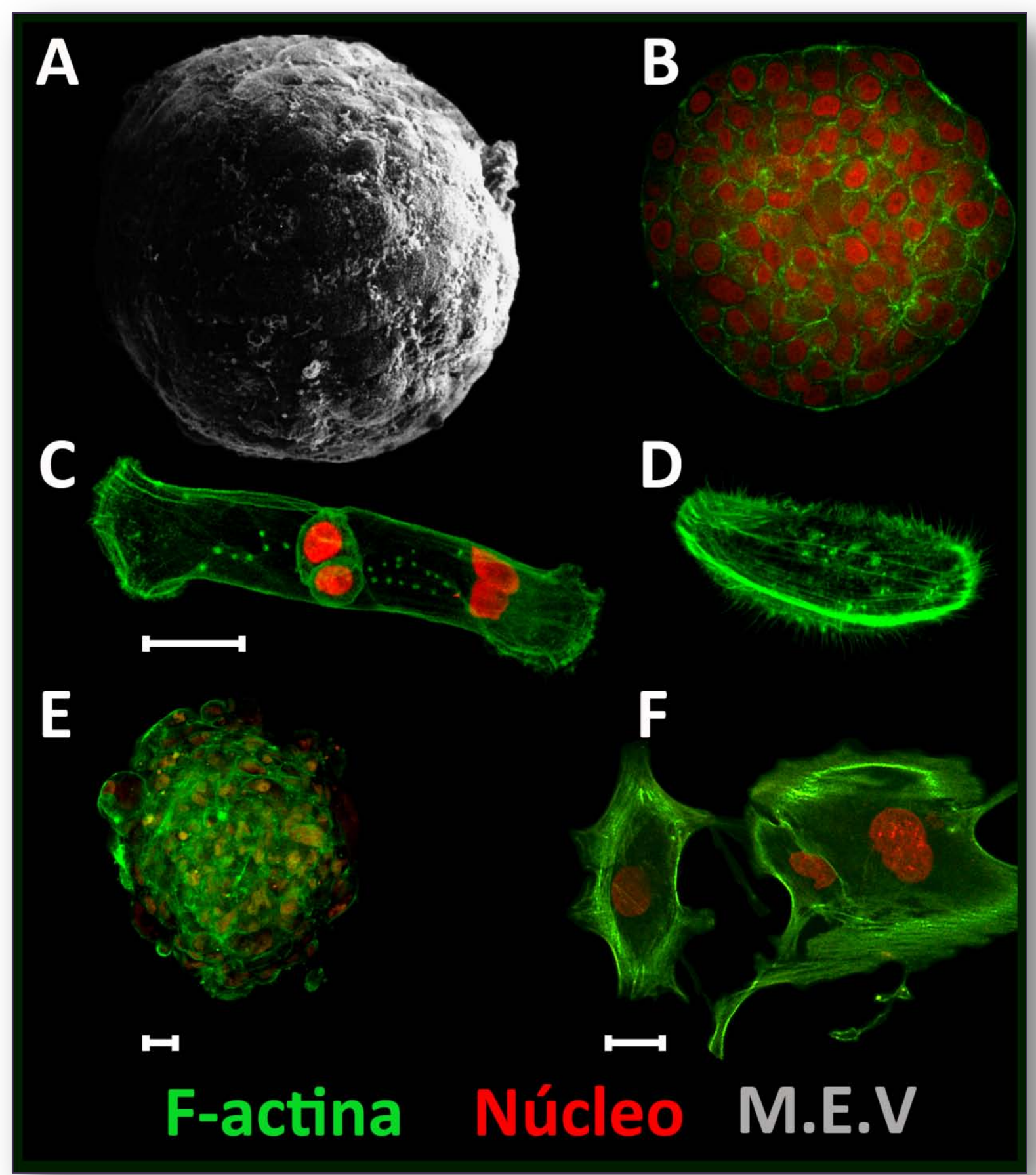

Figura 8 - Prancha composta por diferentes imagens onde se observa a morfologia de algumas linhagens de mama em monocamada ( $C, D$ e $F$ ) e quando crescidas em cultura 3D ( $A, B$ e $E$ ). A Figura C e D mostra a linhagem MCF 10A, a qual não formou esferóides. Figuras $A$ e $B$ representam T47-D e E e F Hs578T. Imagens obtidas ao microscópio eletrônico de varredura (M.E.V) e ao microscopio confocal de varredura a laser. lodeto de propídeo (vermelho) e faloidina acoplada a FITC (verde) foram usados nas marcações fluorescentes. Barra equivale 25 $\mu \mathrm{m}$. 
4.1.1 A linhagem MCF-7 e seu uso na cultura 3D

As células MCF-7 (Figura 9) mantidas em monocamada tiveram o seu número de células contado por um período de 10 dias. A partir destes resultados foi calculado a fase log (crescimento exponencial) sendo elaborado assim um gráfico com a curva de crescimento celular (Figura 9A). Utilizando-se destes dados foi padronizado que a data de coleta e início da cultura em 3 dimensões fosse à partir do 3 o dia de cultura em monocamada pois, neste período, as células se encontram na maior fase de proliferação.
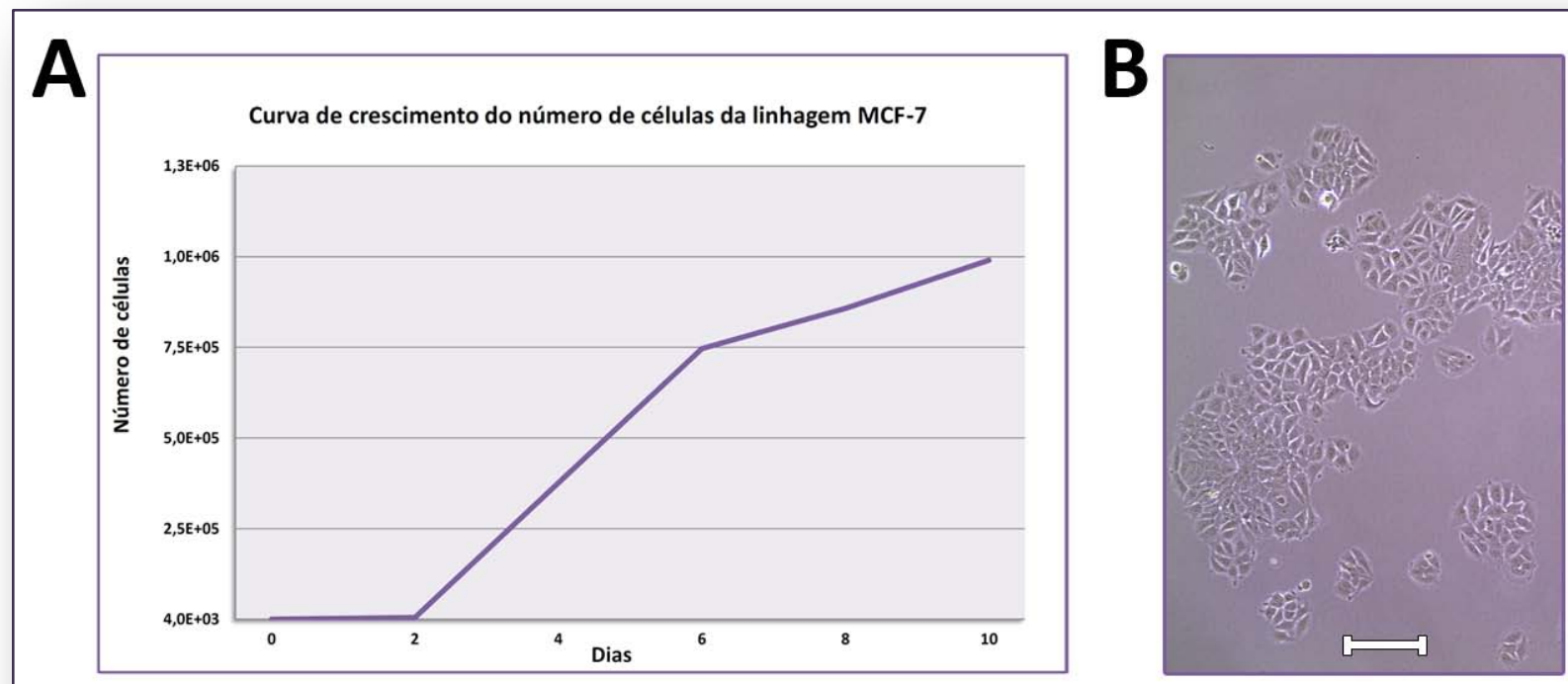

Figura 9 - Gráfico mostrando o aumento do número de células MCF-7 ao longo do tempo (A). Imagem das células MCF-7 crescidas em monocamada vistas ao microscópio de luz com contraste de fase (B). Barra equivale $200 \mu \mathrm{m}$.

Quando analisadas ao microscópio de luz utilizando o contraste de fase, foi observado que a maioria das células se encontrava isolada após a imersão em meio de cultura. Todavia a formação dos esferóides em ambiente 3D ocorreu predominantemente por agregação destas células e não por divisões celulares de uma única célula. O tempo de formação destes agregados ocorreu em média após o 3ำ dia na cultura em 3 dimensões sendo que, após esse período, os esferóides alteraram a sua morfologia passando a ter uma superfície mais coesa e com maior interação entre as células (Figura 10A, B e C). A superfície dos esferóides voltada para o meio de cultura foi analisada ao microscópio eletrônico de varredura (Figura 10D,E e F). Como conseqüência do arranjo e morfologia celulares, as membranas das células MCF-7 foram 
diferentemente expostas ao meio (Figura 10E), sendo possível observar nestas superfícies diversas projeções da membrana celular (Figura 10F).

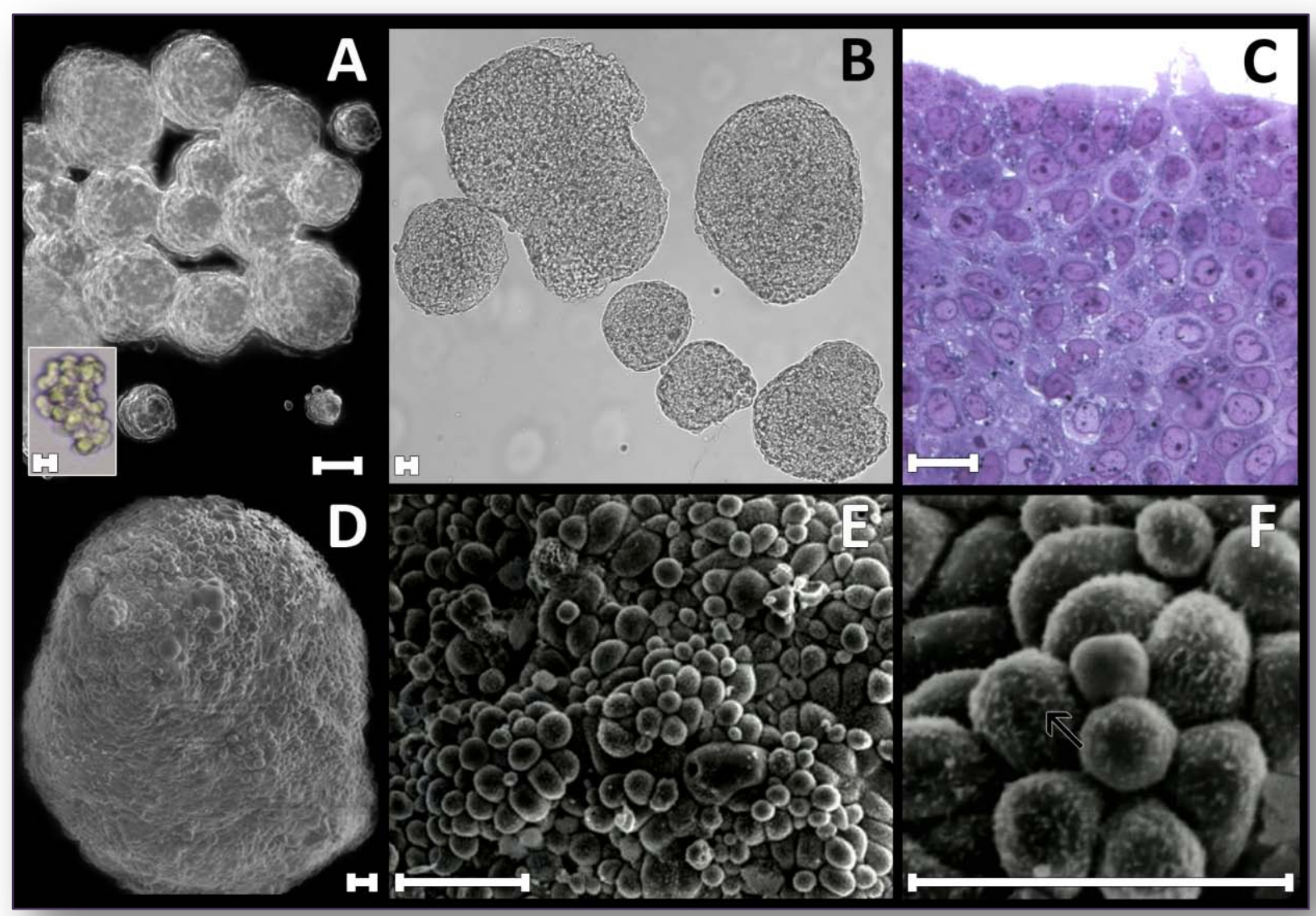

Figura 10 - Fases iniciais da cultura 3D, mostrando desde os agregados de células MCF-7 com 1 dia de cultura (detalhe em A), esferóides com 3 dias (A), 7 dias (B) e quando vistos com 10 dias de cultura (C). Os esferóides foram analisados em maior aumento (D-F, aqui com 30 dias) onde foi possível observar uma exposição diferencial da superfície das células ao ambiente externo (E) bem como projeções da membrana celular (indicada pela seta em F) O material foi analisado ao microscópio de luz com campo claro e contraste de fase ( $\mathrm{A}$ e B) por meio de cortes corados com azul de toluidina utilizando microscopia de luz (C) e por microscopia eletrônica de varredura (D-F). Barra equivale $25 \mu \mathrm{m}$. 
À medida que se aumentava o tempo de cultura, tornou-se evidente um gradativo crescimento dos esferóides decorrente de uma proliferação celular. A confirmação de tal fato ocorreu em paralelo com a morfologia (visualização de figuras de mitose) quando foi utilizado um ensaio de incorporação de BrdU (5-bromo-2-desoxiuridina). Essa técnica permitiu observar a síntese de DNA nos esferóides (Figura 11).

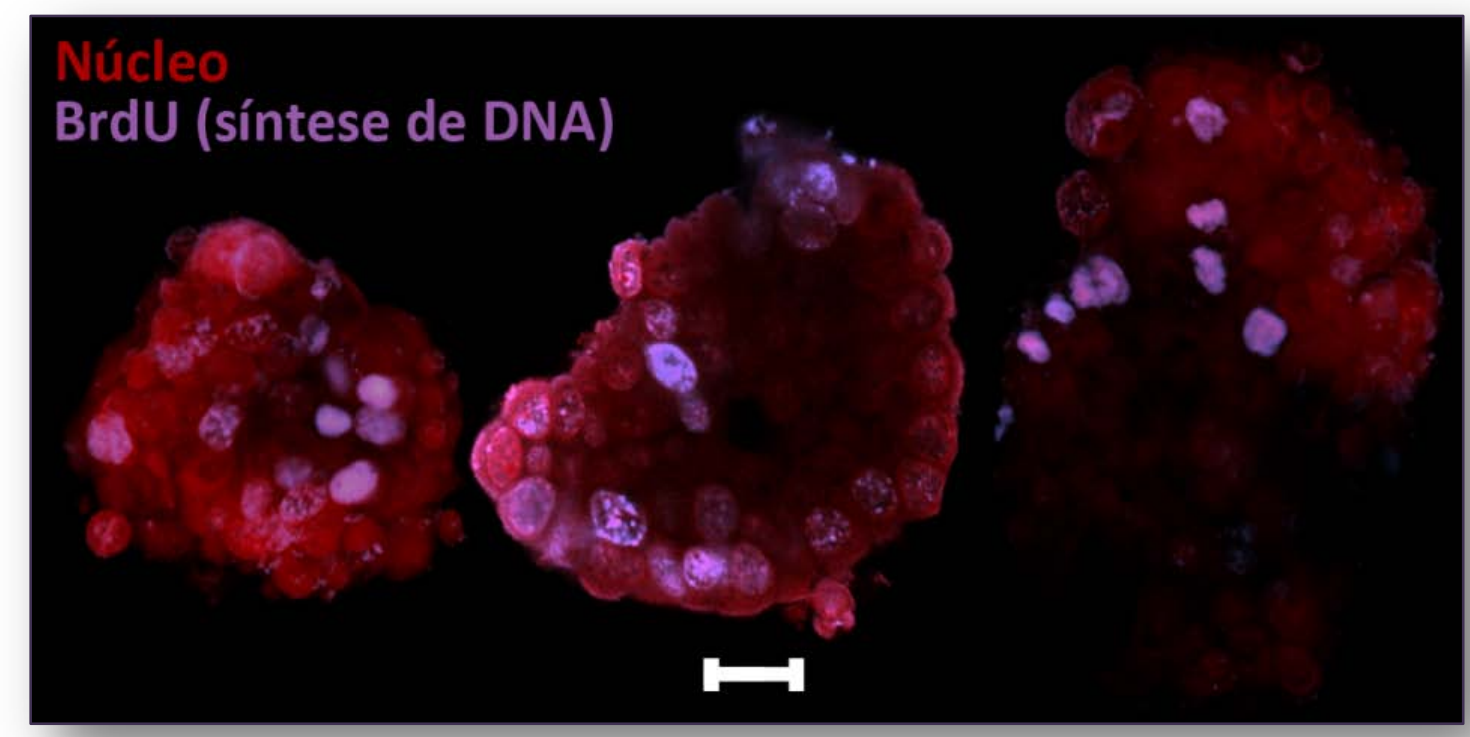

Figura 11 - Esferóides da linhagem MCF-7 submetidos a 7 dias de cultura 3D. Destaque para a marcação para anti-BrdU (azul), mostrando células que estavam em a síntese do DNA. Para a marcação fluorescente foi utilizado iodeto de propídio para visualizar o DNA (vermelho) e o anticorpo secundário Alexa ${ }^{\circledR} 633$ para marcar o anticorpo anti-BrdU. Reconstruções foram obtidas ao microscópio confocal de varredura a laser. Barra $20 \mu \mathrm{m}$

Essa primeira fase do estudo provou a viabilidade do método, haja visto que mesmo após a perda de adesão celular as células MCF-7 formaram esferóides estáveis. A partir deste momento o foco da pesquisa voltou-se para quais seriam as possíveis modificações nos esferóides em períodos mais longos de cultura 3D. Foi observado que a morfologia esférica sofreu alterações ao longo do tempo devido a uma agregação contínua entre células e também entre esferóides. Entretanto, tal fato associado à própria proliferação celular fez com que os esferóides aumentassem seu tamanho ao longo do tempo.

Ao redor do 20 일 de cultura e com diâmetro médio de $300 \mu \mathrm{m}$, os esferóides das células MCF-7 (quando analisados ao microscópio de luz), começaram a apresentar uma área escurecida localizada centralmente na região medular (Figura 12A). Ao longo do tempo foi 
observado crescente aumento desta região, sendo que ao redor do 30 을 esse crescimento mostrou certa estabilização no que se refere à forma esférica (Figura 12B). Em uma análise inicial, utilizando-se de cortes histológicos corados com azul de toluidina, foi verificado a presença de corpos apoptóticos bem como células com morfologia características de processos de apoptose e necrose (Figura 12D).

Ao mesmo tempo em que ocorria o crescimento da região medular, a região cortical apresentou o surgimento de agrupamento de células os quais se mostraram semelhantes a brotamentos (Figura 12A-C e 13C). Estas estruturas foram descritas nas culturas a partir do 20은 dia, apresentando um crescimento constante o qual foi acompanhado por até 155 dias (Figura 13D).

Estes resultados mostraram boa adaptação das células MCF-7 ao ambiente 3D, o qual possibilitou a descrição das alterações da morfologia destes esferóides. Posteriormente a essa análise inicial, verificamos quais seriam as relações entre alterações na morfologia e citoesqueleto. Para tanto, foram analisados possíveis modificações nos microfilamentos de actina e nos microtúbulos sendo estes observados por microscopia confocal de varredura a laser. 


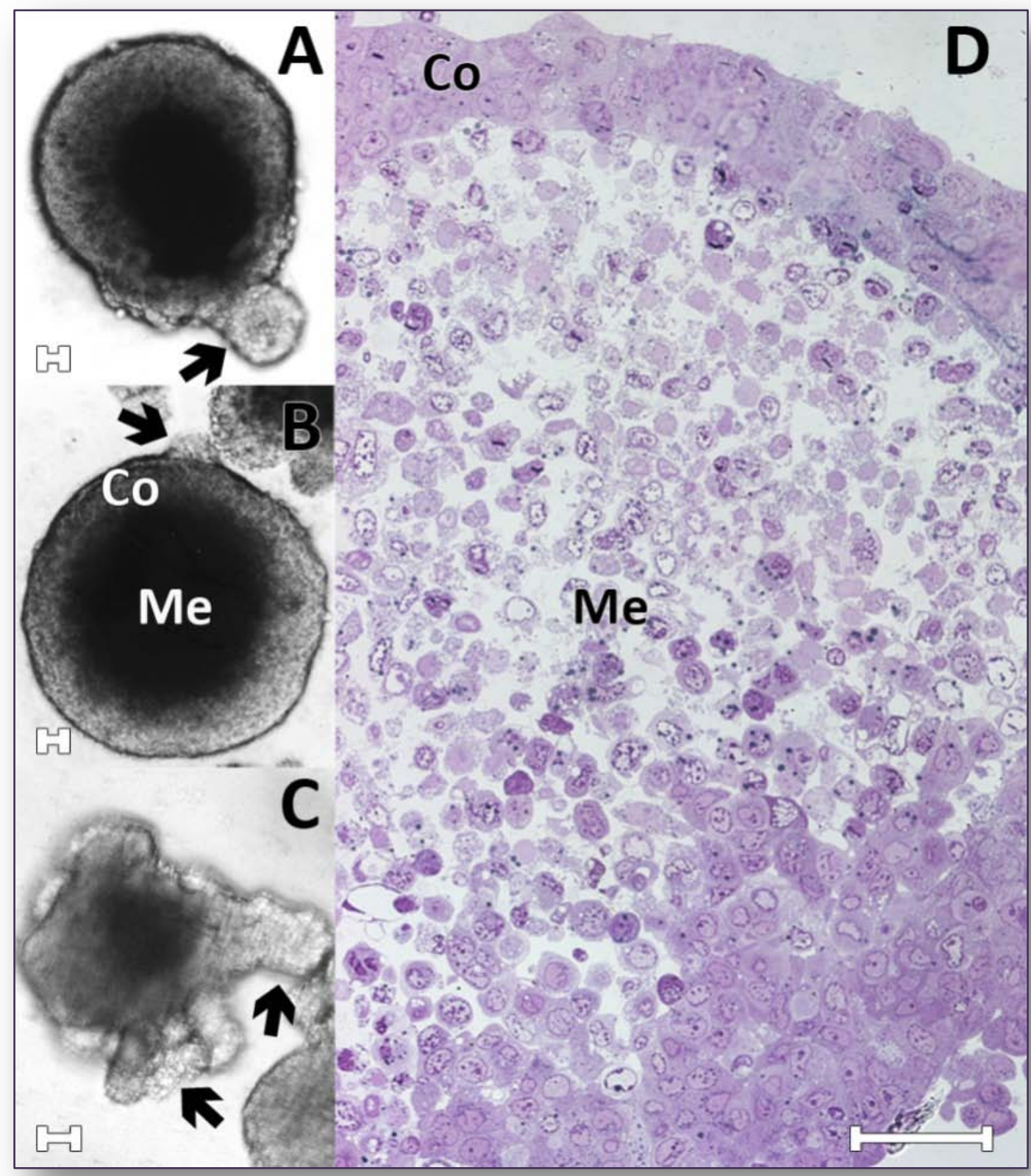

Figura 12 - Esferóides da linhagem MCF-7 submetidos à cultura 3D por 20 (A e B) e 30 dias (C e D). Note a formação da região medular (M) a qual foi posteriormente acompanhado pelo crescimento de um brotamento com células (seta) na região cortical (Co). A análise de cortes histológicos corados com azul de toluidina mostrou a heterogeneidade celular da região medular (D). Fotos obtidas ao microscópio de luz com campo claro. Barra $50 \mu \mathrm{m}$ 


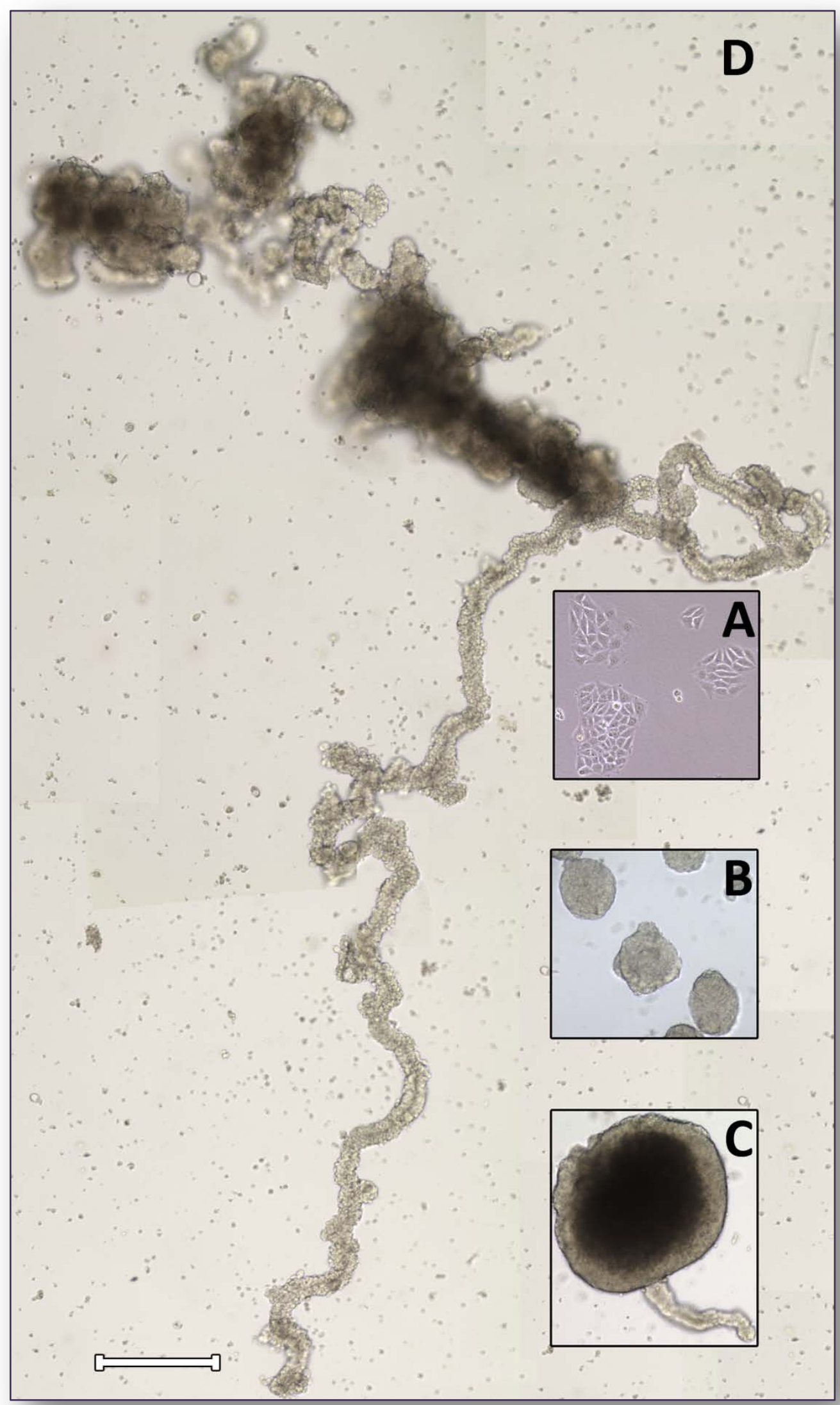

Figura 13 - Alterações na morfologia das células MCF-7 desde a monocamada (A) 7 dias (B), 30 dias (C) e 50 dias de cultura 3D (D). Imagens obtidas ao microscópio de luz com campo claro. Barra 400 $\mu \mathrm{m}$. 


\subsection{ORGANIZAÇÃO DOS MICROFILAMENTOS DE ACTINA E DOS MICROTÚBULOS}

4.2.1 Células em monocamada (2D)

As modificações foram evidenciadas por reconstruções em 3-dimensões de imagens obtidas ao microscópio confocal de varredura a laser. Nas fases iniciais da cultura as células recém aderidas apresentaram protusões indicativas de atividade migratória (Figura 14A e B), sendo possível observar que marginalmente a membrana destas estruturas, houve uma maior intensidade de marcação para os microfilamentos actina (Figura 14A). Tais componentes também se mostraram arranjados em pequenas pontuações, preferencialmente localizadas na superfície de contado com o substrato (Figura 14B). Na monocamada também foi possível observar a formação de fibras tensionadas (stress fibers). Estes agregados lineares de microfilamentos estão localizados tanto marginalmente aos limites celulares, como também de forma retilínea no citoplasma (Figura 14C). Também foi observada uma intensa marcação para os microfilamentos de actina em regiões de contato entre as células (Figura 14D).

A organização dos microtúbulos, ao contrário do descrito para actina, apresentou poucas diferenças de localização no interior das células analisadas (Figura 14). Concentrados na região perinuclear e dispostos radialmente no citoplasma da célula, os microtúbulos estenderam-se até muito próximo dos limites celulares. A disposição típica deste componente do citoesqueleto também foi confirmada nas células mitóticas, onde foram observados microtúbulos arranjados de forma peculiar para a formação do fuso mitótico (Figura 14D). 


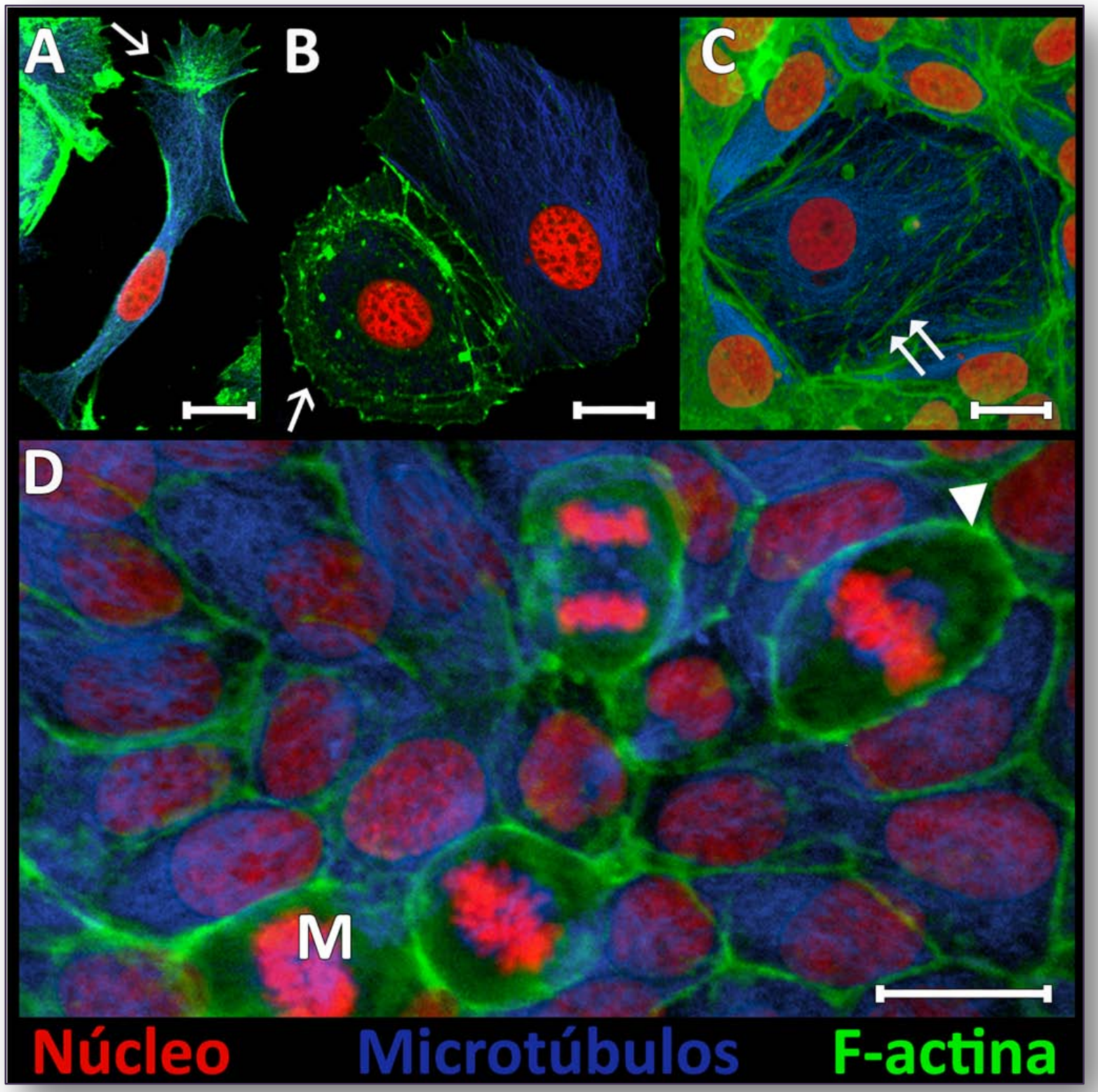

Figura 14 - Células MCF-7 crescidas em monocamada. Foi possível observar a maior concentração dos microfilamentos de actina nas protrusões das células (seta), nas fibras tensionadas (stress fiber) e entre células contíguas (cabeça de seta). Os corantes fluorescentes usados foram iodeto de propídio (em vemelho) e faloidina conjugada a FITC (verde). Em azul foram utilizados anticorpo anti $\alpha$ e anti $\beta$ tubulina, sendo posteriormente marcados com anti-IgG de camundongo conjugado com CY5. M = mitose. Barra $20 \mu \mathrm{m}$. Imagens obtidas ao microscópio de confocal de varredura a laser 


\subsubsection{Células crescidas em culturas 3D}

Em paralelo as descrições dos componentes do citoesqueleto, a microscopia confocal de varredura a laser possibilitou a obtenção de maiores informações a respeito das alterações morfológicas dos esferóides ao longo do tempo de cultura. As Figuras 15A, B e C mostram esferóides com 3, 5 e 7 dias de cultura 3D respectivamente.

Nos primeiros dias de cultura, foi possível observar que a marcação para os microfilamentos de actina apresentou-se mais intensa nas células localizadas na região central quando comparadas com as células mais periféricas ao esferóide (Figura 15A).

Ao redor do 5o dia de cultura os esferóides começaram a apresentar uma marcação para F-actina mais homogênea (Figura 15B). Associado a isso, tornou-se cada vez mais evidente um crescente contato entre as células. Essa maior interação também ocorreu em esferóides com 7 dias (Figura 15C) os quais mantiveram a sua morfologia esférica com uma maior densidade de células, esta, resultante principalmente de processos de divisão celular (evidenciados por figuras de mitose).

Ao longo do tempo de cultura 3D o córtex dos esferóides apresentou-se como uma área bastante interessante, pois, nesta região, foi observada uma proliferação celular diferenciada acarretando na formação de estruturas denominadas de brotamentos corticais. Na Figura 15D foi possível verificar o dinamismo deste processo, haja visto que em um mesmo esferóide (aqui com 30 dias de cultura) foi visualizado brotamentos em fase inicial ocorrendo ao mesmo tempo que brotamentos bastante desenvolvidos. Inserido neste panorama, duas características mostraram-se importantes: a crescente morte celular (evidenciadas nesta análise por meio da presença de fragmentos celulares e núcleios picnóticos) e a morfologia alongada assumida por esses brotamentos. A morte celular nesta fase pode, nos esferóides maiores (acima de 300 $\mu \mathrm{m})$, estar relacionada ao aumento da hipóxia e diminuição de nutrientes. Todavia o que nos chamou mais a atenção foi a presença deste processo no interior das estruturas alongadas e o seu papel ativo nas modificações dos esferóides, fazendo com que estes assumissem uma morfologia acinar.

Ao redor de 50 dias (apesar de estarem presentes desde o 30 dia de cultura), ficou evidente a predominância de estruturas alongadas quando comparado com o esperado arranjo 
esférico das culturas 3D (Figura 15E e F). Adicionado a isto, de forma progressiva, os esferóides com essa morfologia modificada mostraram uma diminuição do número de células da sua região medular. Por meio de reconstruções de secções ópticas, obtidas ao microscópio confocal de varredura a laser, foi observada a formação de uma camada contínua constituída por uma monocamada de células. Presente tanto nas estruturas acinares (Figura 15G, com 75 dias) quanto nas tubulares (Figura $15 \mathrm{H}$ com 155 dias) esta monocamada cortical margeou uma cavidade recém formada, a qual foi denominada espaço luminal (Figuras 16 e 17). Foi verificada nas camadas mais externas destes esferóides diferenciados (principalmente ao redor do arranjo acinar) a presença de componentes de laminina- fato este indicativo de polarização destas células (Figura 18C). 

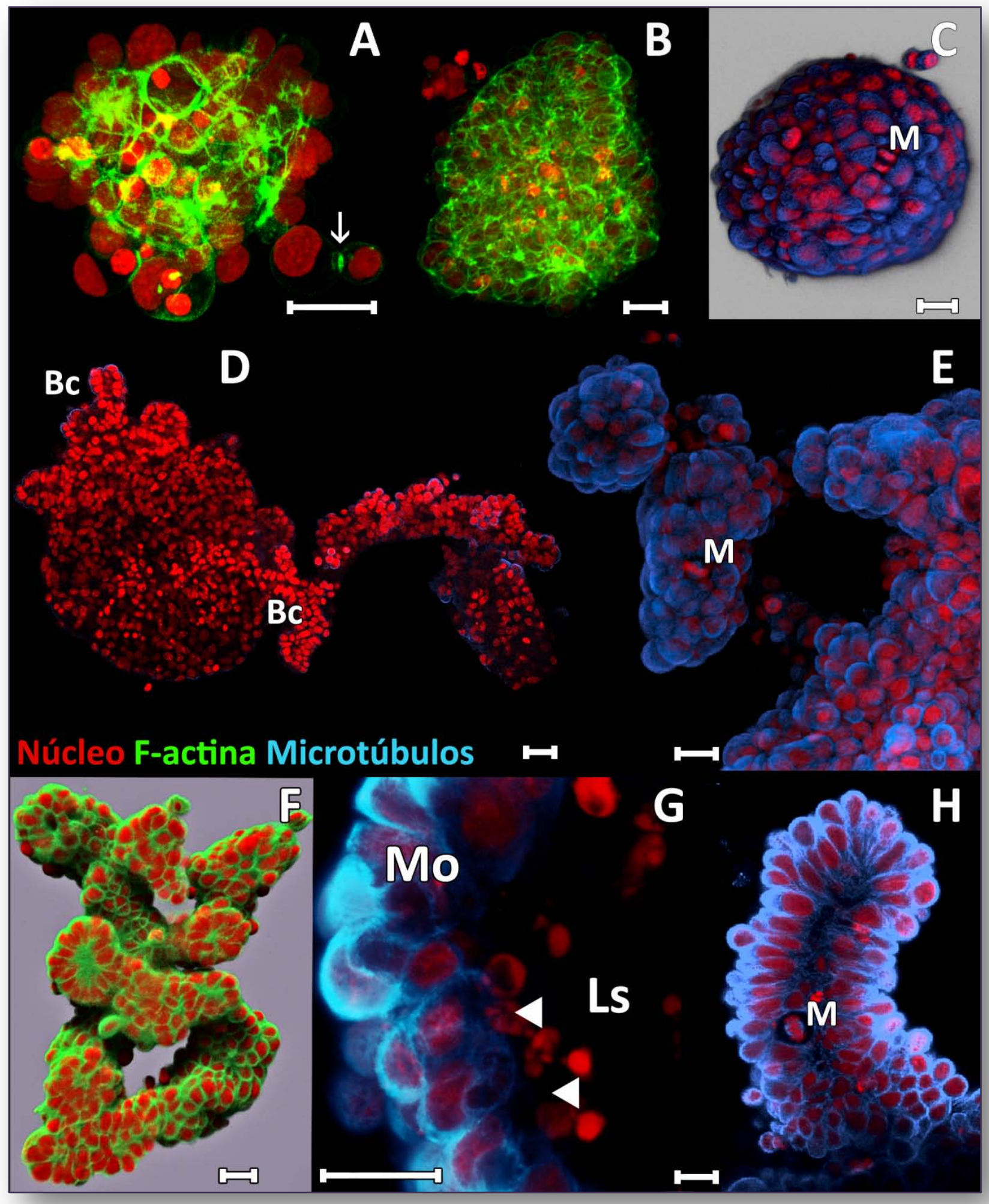

Figura 15 - A legenda desta prancha está localizada no verso da página ao lado. 
Os resultados encontrados mostraram que os microtúbulos, no contexto da cultura 3D, apresentam as mesmas características descritas para a monocamada (Figura 15C, D, E G e H). Todavia, o outro componente analisado -os microfilamentos de actina- apresentaram-se arranjados de forma peculiar nessas culturas mais diferenciadas. Todas as células da camada cortical, estas voltadas para o espaço luminal, mostraram na região apical uma intensa marcação para actina. Tal característica delimitou toda área do espaço luminal (Figura 16, 17 e 18), deixando bem claro a ligação das estruturas tubulares com as acinares (Figura 17). A proliferação celular também ocorreu nestes esferóides tubulares, fato este verificado por meio de ensaios com BrdU (Figura 18B).

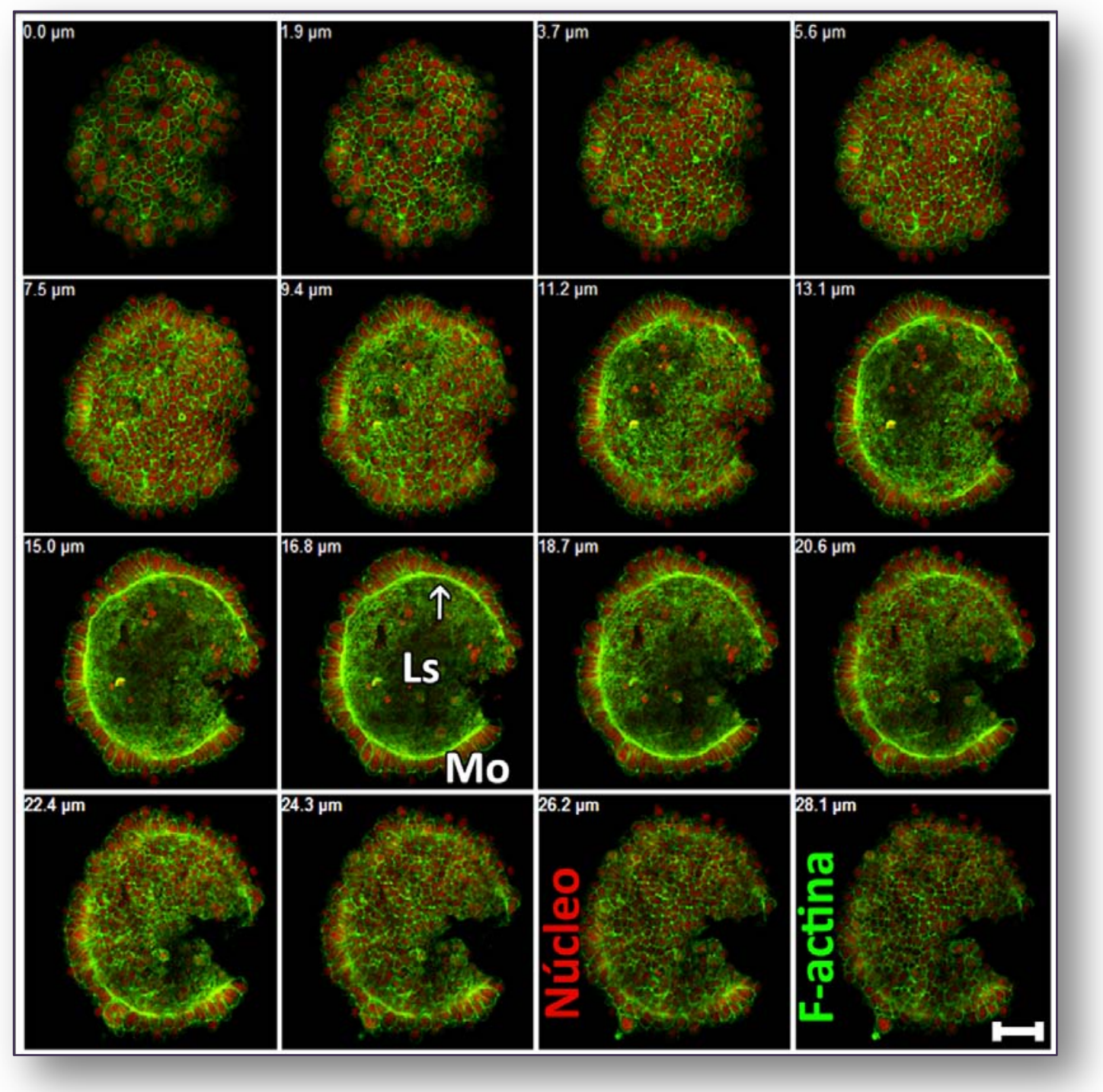

Figura 16 - Esferóides de células MCF-7 com 75 dias. As células estão arranjadas em uma monocamada (Mo), voltadas para uma luz (Ls). Note a maior concentração dos filamentos de actina na região apical destas células (seta). Os corantes fluorescentes usados foram o iodeto de propídio (em vermelho) e faloidina conjugada a FITC (verde). Barra $50 \mu \mathrm{m}$. Secções ópticas obtidas ao microscópio de confocal de varredura a laser. 


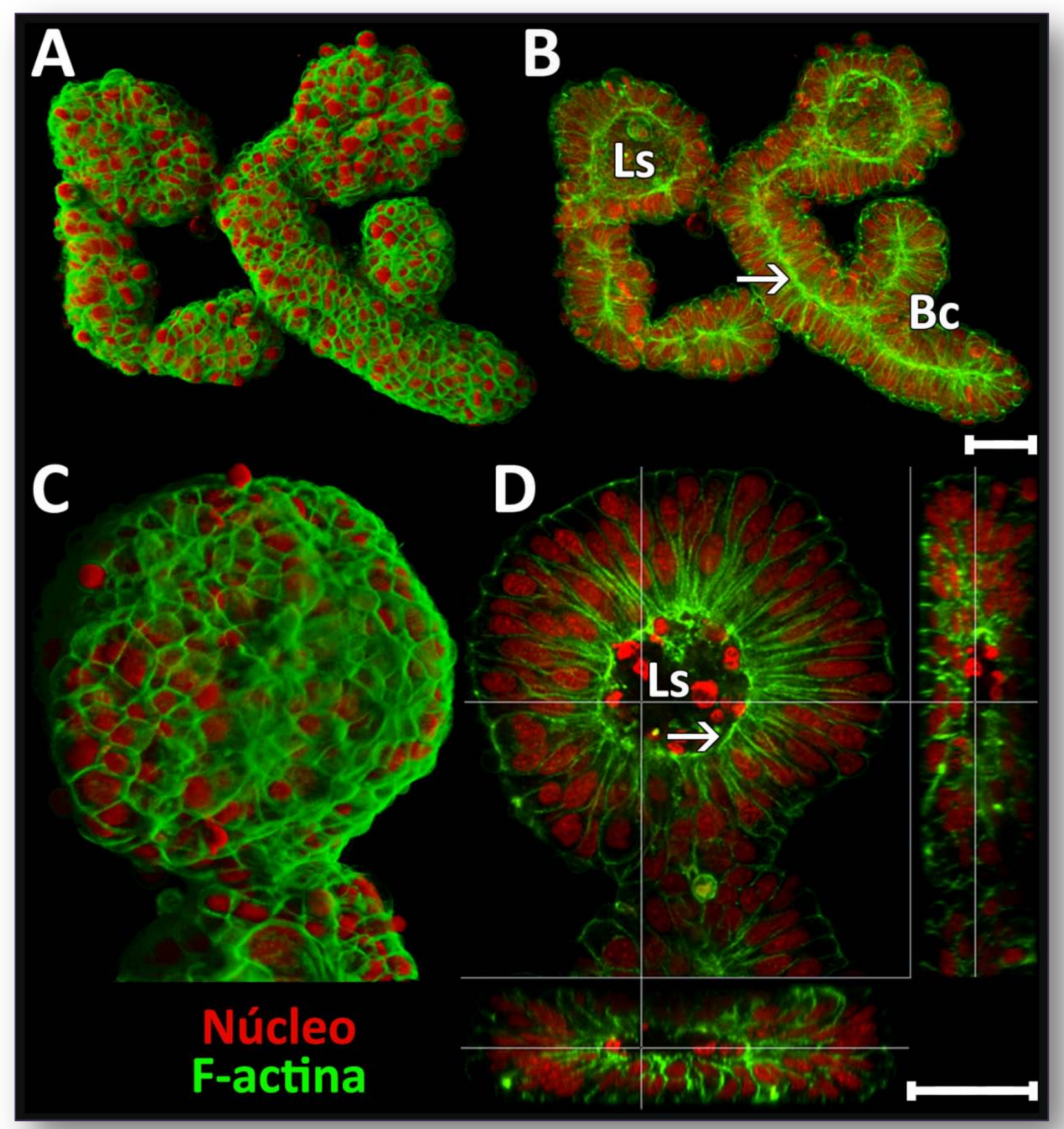

Figura 17 - Células MCF-7 crescidas por 75 dias em cultura celular em 3 dimensões. Foi possível observar que o acúmulo de actina está presente por toda a cavidade luminal (tanto na porção acinar quanto na tubular) (seta em B e D). Em D, região com arranjo acinar vista em corte ortogonal. Os corantes fluorescentes usados foram iodeto de propídio (em vermelho) e faloidina conjugada a FITC (verde). Barra $50 \mu \mathrm{m}$. As reconstruções foram obtidas ao microscópio de confocal de varredura a laser. Imagens obtidas utilizando o software Imaris 7.1 ( $\mathrm{A}$ e $\mathrm{C})$. 


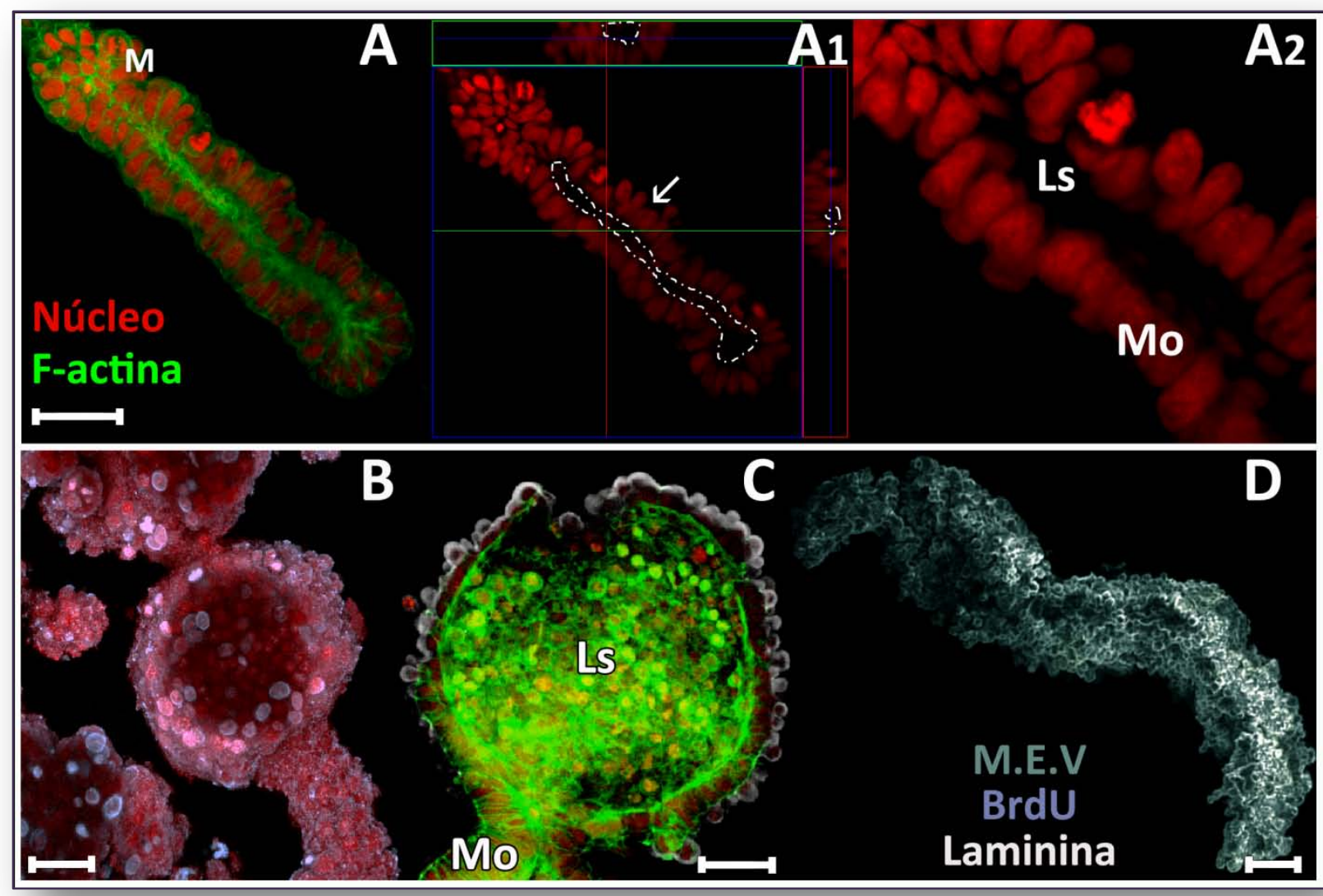

Figura 18 - Arranjo tubular de esferóide com 50 dias de cultura (A). Em A1 foi possível observar a cavidade no interior do esferóide (linhas tracejadas em branco) (visto em corte ortogonal). Em maior detalhe desta estrutura (A3) foi possível observar o arranjo em monocamada (Mo). A Figura B mostra síntese de DNA em esferóides com 75 dias. Em esferóides com esse mesmo tempo de cultura foi possível observar células da camada cortical positivas para laminina (C). Esferóide com 75 dias observado ao microscópio eletrônico de varredura (M.E.V) (D). Os corantes fluorescentes usados foram iodeto de propídio (em vermelho) e faloidina conjugada a FITC (verde). Ambas as imunomarcações foram evidenciadas com anti-IgG de camundongo conjugado a CY5. M=mitose Barra $50 \mu \mathrm{m}$. Imagens $\mathrm{A}-\mathrm{C}$ foram obtidas ao microscópio de confocal de varredura a laser

Os resultados obtidos por microscopia confocal a laser mostraram que a formação de estruturas alongadas não era somente uma resultante de agregação de células ao acaso. Além disso, esta técnica possibilitou verificar a gradual formação de uma estrutura luminal cercada por esferóides modificados em túbulos e ácinos. Com o objetivo de ter uma maior resolução deste processo, os esferóides seguiram para uma análise ultraestrutural, a qual será mostrada a seguir. 


\subsection{MICROSCOPIA ELETRÔNICA DE TRANSMISSÃO}

As gradativas mudanças na morfologia dos esferóides ao longo do tempo apontavam para uma seqüência de eventos os quais resultaram na formação de estruturas tubulares/acinares com arranjo luminal. Entre esses eventos, foi mostrado previamente que a apoptose presente na região medular e a concomitante diminuição do número de células da região cortical estariam atuando como protagonistas destas modificações. A técnica de microscopia eletrônica de transmissão inseriu-se neste contexto devido ao fato de atuar como um experimento comprobatório de alguns processos, podendo citar como exemplo as alterações celulares presentes na via autofagia.

Nas fases iniciais da cultura 3D (nos primeiros 10 dias) as células da linhagem MCF-7 mostraram uma interação bastante heterogênea decorrente da disposição de suas membranas celulares. As células arranjadas preferencialmente de forma esférica, mantiveram pontos de contato com suas vizinhas os quais aumentavam a sua interação ao longo do tempo. Outras células mostraram-se dispostas mais corticalmente, expondo parte de sua membrana para a face externa do esferóide (como já mostrado em microscopia eletrônica de varredura). Na região cortical foram observados células com morfologia esférica intercaladas com células mais alongadas tendo como conseqüência áreas diferentemente expostas a face externa do esferóide. A atividade proliferativa mostrada com ensaios de BrdU também foi confirmada pela presença de figuras de mitose, as quais foram caracterizadas por células esféricas que em seu interior mostravam secções de cromossomos (devido o efeito de corte) bastante elétron densos (Figura 19A). A razão entre eucromatina/heterocromatina aponta para a atividade metabólica das células. Neste contexto, foi observado nesta fase inicial que a maioria dos núcleos das células MCF-7 não estavam compactados, mas sim, apresentando uma maior quantidade de eucromatina e também com nucléolos evidentes. 


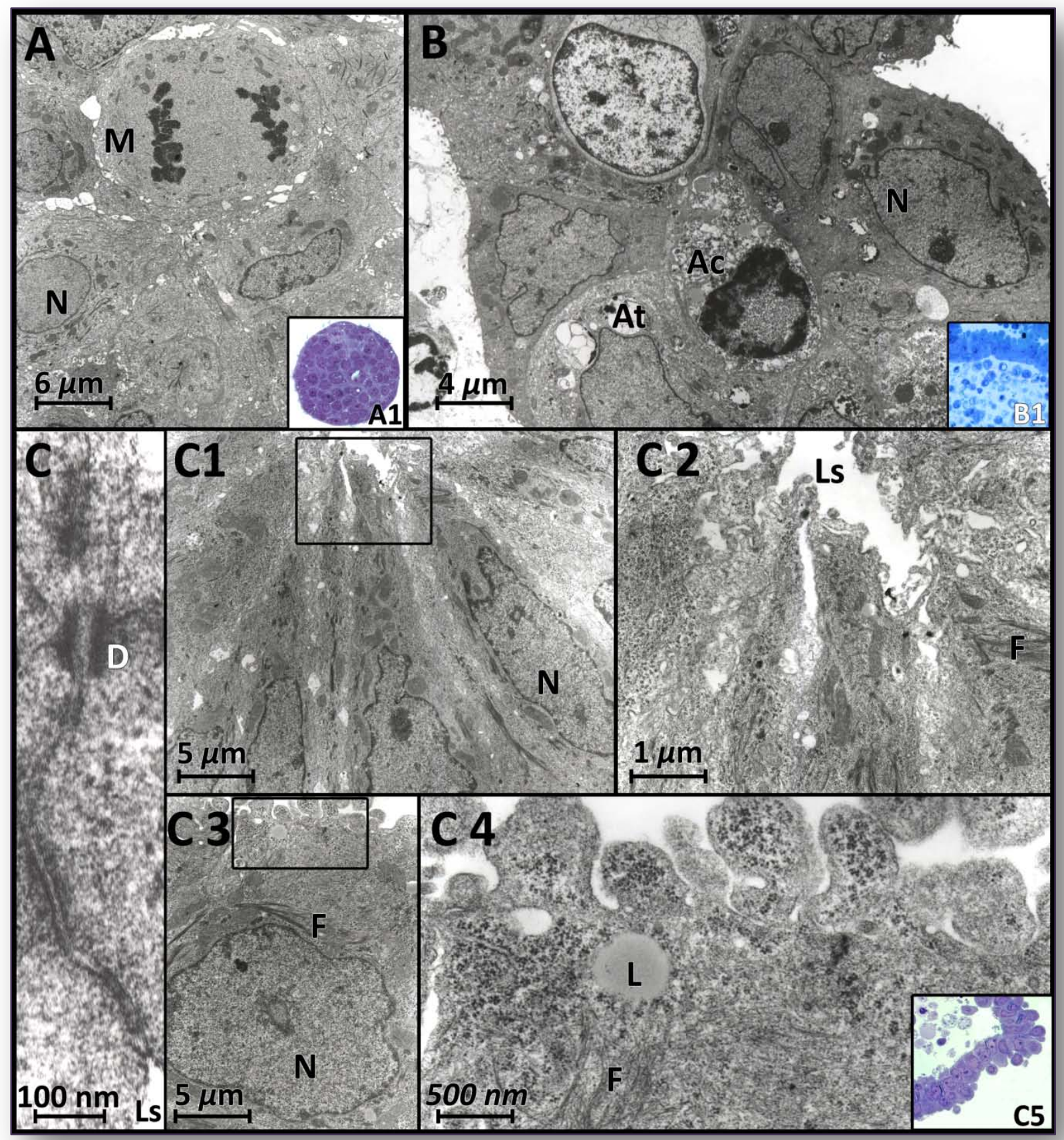

Figura 19 - A morfologia da camada cortical de esferóides de células MCF-7 sofreu alterações ao longo tempo, passando por uma fase proliferativa ( 5 dias em A) posteriormente seguida por uma crescente diminuição do número de células (mostrada em $B$ com 30 dias). Com a espessura próxima a uma monocamada, as células desta região mostraram um arranjo polarizado com a presença de junções celulares (C) e um arranjo colunar com a região apical voltada para o espaço luminal (Ls) (mostrado nos destaques de C1 e C3 com 75 dias de cultura). Imagens foram obtidas ao microscópio eletrônico de transmissão, sendo que A1, B1 e C5 são regiões equivalentes em cortes histológicos corados com azul de toluidina e vistas ao microscópio de luz. C2 e C4 mostram em detalhe a superfície apical voltada para a região luminal. At=autolisossomo, Ac=célula apoptótica, $\mathrm{D}=$ desmossomo, $\mathrm{F}=$ filamentos Intermediários, L=lipídeos, $\mathrm{M}=$ mitose. 
Posteriormente a esta fase, o foco da nossa análise foi a formação da região medular e a formação da camada cortical. Para tanto, analisamos esferóides com 25, 30, 45, 75 e 155 dias de cultura 3D. Diferentemente da análise anterior, a interface entre as camadas medular e a cortical tornou-se bastante evidente ao longo do tempo. Isso se deu pelo fato de que na camada medular o contato entre as células MCF-7 é bem menos intenso quando comparado com a região cortical (compare as Figuras 19A e 19B).

Em um primeiro momento, observamos na camada cortical células arranjadas de maneira semelhante ao encontrado nos esferóides iniciais, todavia, a visualização de células com diferentes elétron densidades bem como com diferentes níveis de compactação nuclear, sugere uma maior diversidade celular tanto no que se refere à morfologia quanto ao seu estado fisiológico. Com uma crescente diminuição do número de células da região cortical (Figura 19B) foram descritas alterações morfológicas que indicam um processo de polarização celular. A primeira destas foi o aumento de junções celulares, principalmente desmossomos. Estas estruturas apresentaram-se organizadas, atuando no aumento da interação célula-célula. A presença de filamentos intermediários e o arranjo destes com os desmossomos também podem ser indicativos de uma maior diferenciação celular. Em concordância com este processo, foi verificada a formação de complexos juncionais (Figura 19C).

A tendência de formação de uma camada de células na região cortical dos esferóides esteve sempre associada à polarização celular. Visto com bastante freqüência a partir de 45 dias, as células desta região começaram a apresentar uma morfologia colunar onde, com uma região apical agora definida, mostraram-se voltadas para a região medular. Ao se examinar em detalhe as projeções de membrana localizadas nesta região, vimos que além de numerosas estas estruturas sugerem que talvez haja a liberação de compostos celulares na região medular em esferóides mais velhos (Figura 19 C2 e C4). Devido a essas características evidenciadas ultra estruturalmente, corroboramos os resultados prévios de microscopia confocal de varredura a laser, os quais apontavam para a formação de um espaço luminal constituído por uma monocamada de células colunares. 


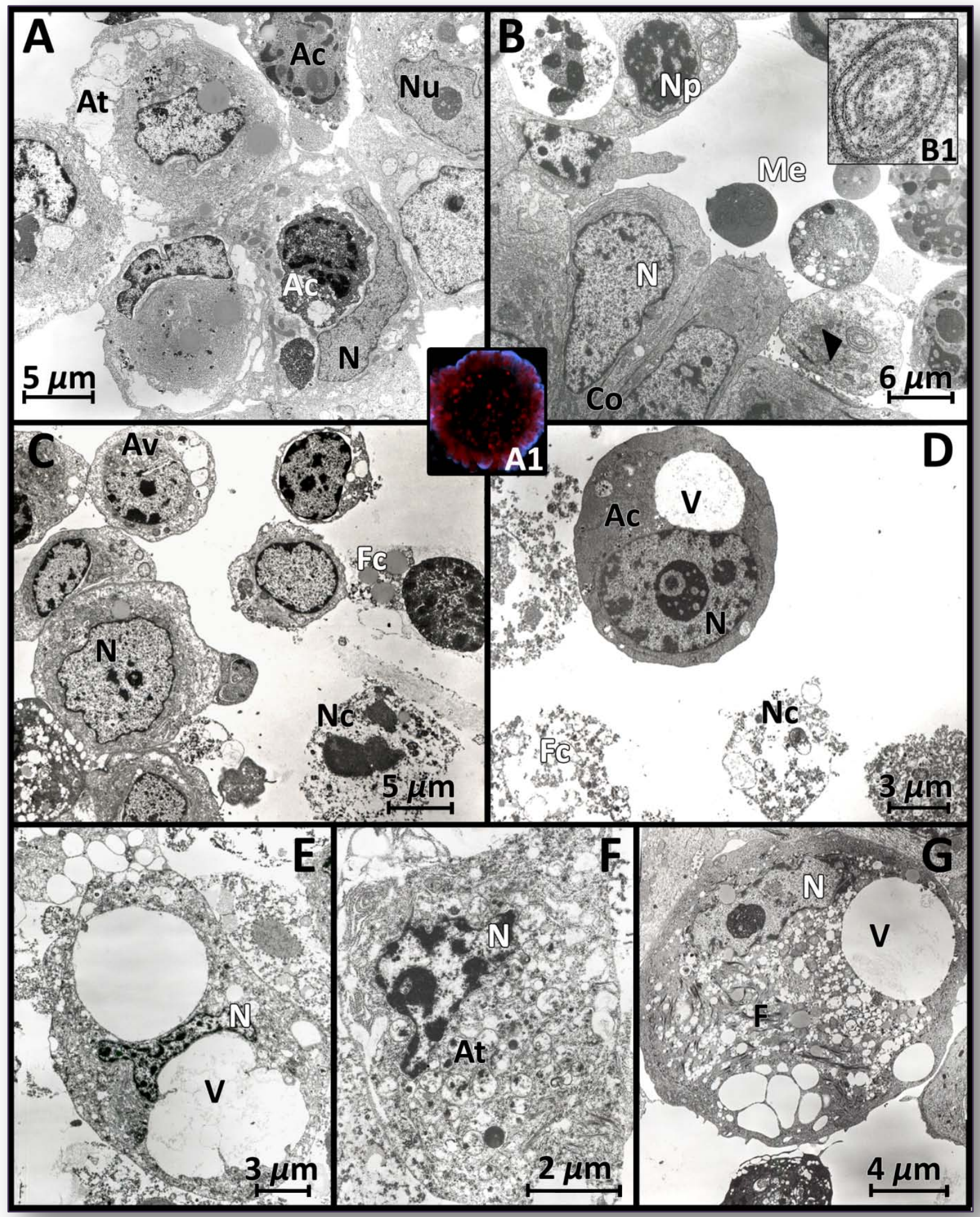

Figura 20 - A legenda desta prancha está localizada no verso da página ao lado 
A região medular, mostrada aqui nas Figuras 20 e 21, foi caracterizada por possuir um menor contato entre as células MCF-7. Tal fato foi decorrente do elevado processo de morte celular nesta região o qual, ao longo do tempo, teve como conseqüência a diminuição da densidade celular (Figura 20A, B e C). Paralelamente a apoptose, a crescente presença de células necróticas sugere a atuação de outras vias fisiológicas na diminuição do número de células (Figuras 20C e D). Algumas células apresentaram um aspecto vacuolizado, muitas vezes decorrentes de intensa atividade autofágica (presença de autolisossomos) ou resultado de degradação celular associada a vias de morte (Figura 20E, F e G).

Em maior detalhe vimos que a gradual compactação e formação de núcleos picnóticos pode esta acompanhada da degradação de componentes do citoplasma (Figura 21A) a qual pode ter como conseqüência a formação de células apoptóticas (Figura 21B) ou células necróticas (Figura 21C e D). A presença de fragmentos celulares pode ter relação com o grande número de células necróticas que, após a perda da integridade da membrana, liberaram seus componentes citoplasmáticos na região medular.

A presença de processos autofágicos foi evidenciada principalmente pelo diagnóstico de vesículas contendo dupla membrana, os autofagossomos. Concomitante a isso, vesículas contendo material elétron denso em degradação apontam para a formação de autolisossomos, os quais foram encontrados tanto em células em processo de autofagia bem como em células em processo de necrose (Figura 21D e E). 


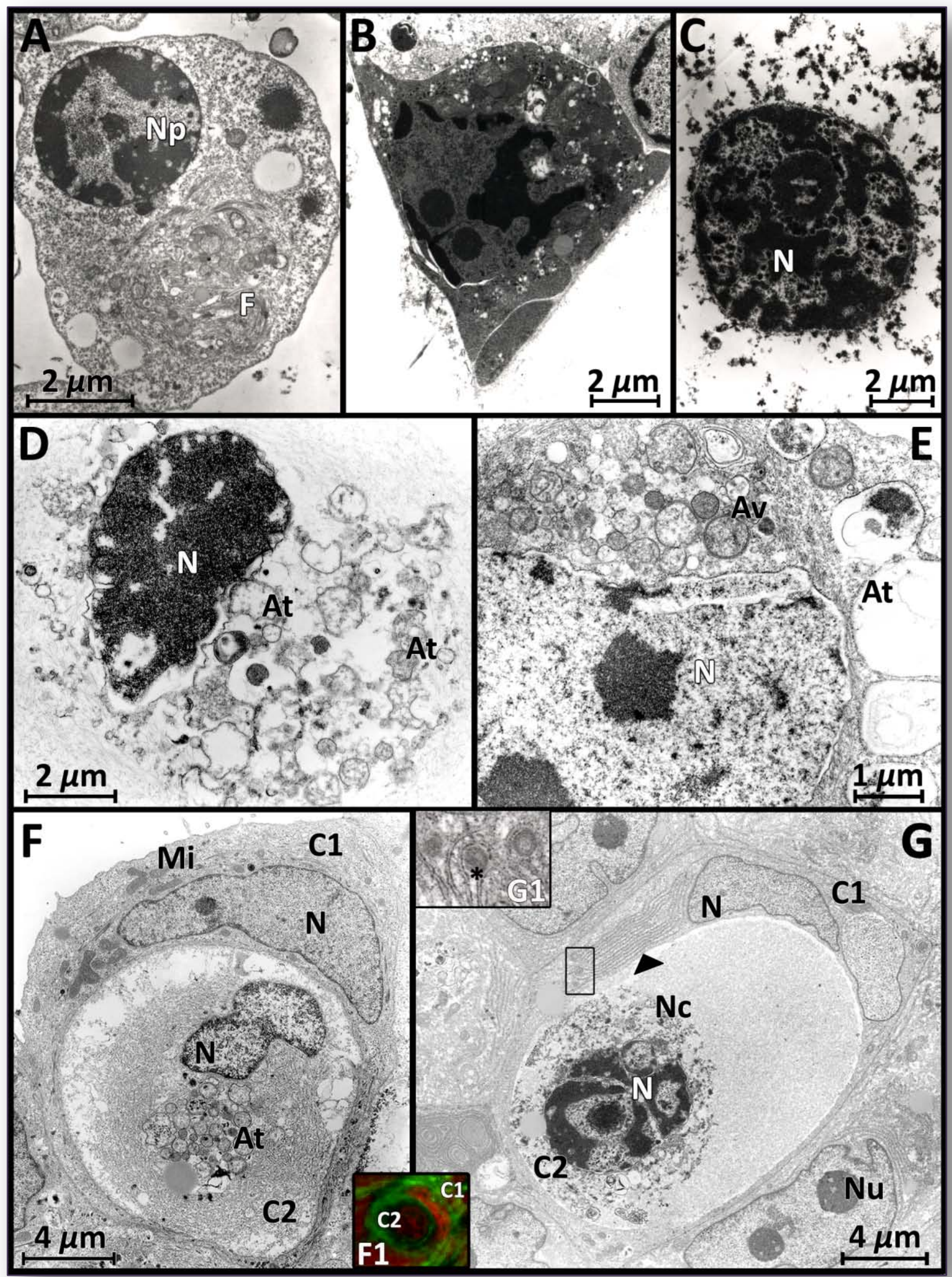

Figura 21 - A legenda desta prancha está localizada no verso da página ao lado 
A presença de células no interior de outras células é uma característica tanto de processos relacionados à fagocitose, bem como entose $(118,119)$. Apesar de esta característica ter sido encontrada nas células analisadas, não é possível, utilizando a ultra-estrutura, delinear qual via celular estaria sendo predominante. Desta forma, foi adotado o termo entose/fagocitose no decorrer deste texto para a descrição deste processo. Tanto na região medular (Figura 21F) quanto na região cortical (Figura 21G) foram observadas o processo de fagocitose/entose. Em todas as células analisadas, a célula interiorizada apresentava elevado grau de degradação dos seus componentes intracelulares. Na Figura21F, foi possível observar uma célula com elevada atividade autofágica (presença de autolisossomos). Na Figura $21 \mathrm{G}$ a célula interiorizada possui elevada fragmentação da membrana e extravasamento do conteúdo citoplasmático, o qual apontaria para processos de necrose celular. O que chama a atenção nesta última imagem é a presença de um retículo endoplasmático rugoso bastante desenvolvido na célula que está interiorizando, sendo possível até observar a formação de vesículas de secreção (Figura 21G1).

A microscopia eletrônica de transmissão adicionou maiores informações a respeito da morfologia celular de células MCF-7 comprometidas com a sinalização para a morte celular. Todavia tornou-se necessário a utilização de marcadores específicos capazes de separar os diferentes tipos de morte celular, bem como quantificar o número de células que estariam passando por esses processos. Assim, a fase posterior de nosso trabalho envolveu principalmente a quantificação por citometria de fluxo dos esferóides analisados. Fato este que mostraremos a seguir. 
4.4 QUANTIFICAÇÃO DA MORTE CELULAR NO MODELO 3D

4.4.1 Marcação das células em apoptose utilizando M30

Devido ao fato de ligar-se com a porção clivada da citoqueratina 18, (processo presente nas fases iniciais da apoptose) a técnica de M30 possibilita a visualização de células apoptóticas antes de apresentarem alterações características deste processo. Foi observada, novamente, predominância de células apoptóticas na região medular sendo esta mais intensa á partir do 30 dia de cultura (Figura 22A). Todavia, mesmo em esferóides com maior tempo de cultura esta marcação também esteve presente no interior do agora recém formado espaço luminal. Em paralelo a isso, novamente foi notado à concomitante presença de núcleos picnóticos e fragmentos nucleares (Figura 22B).

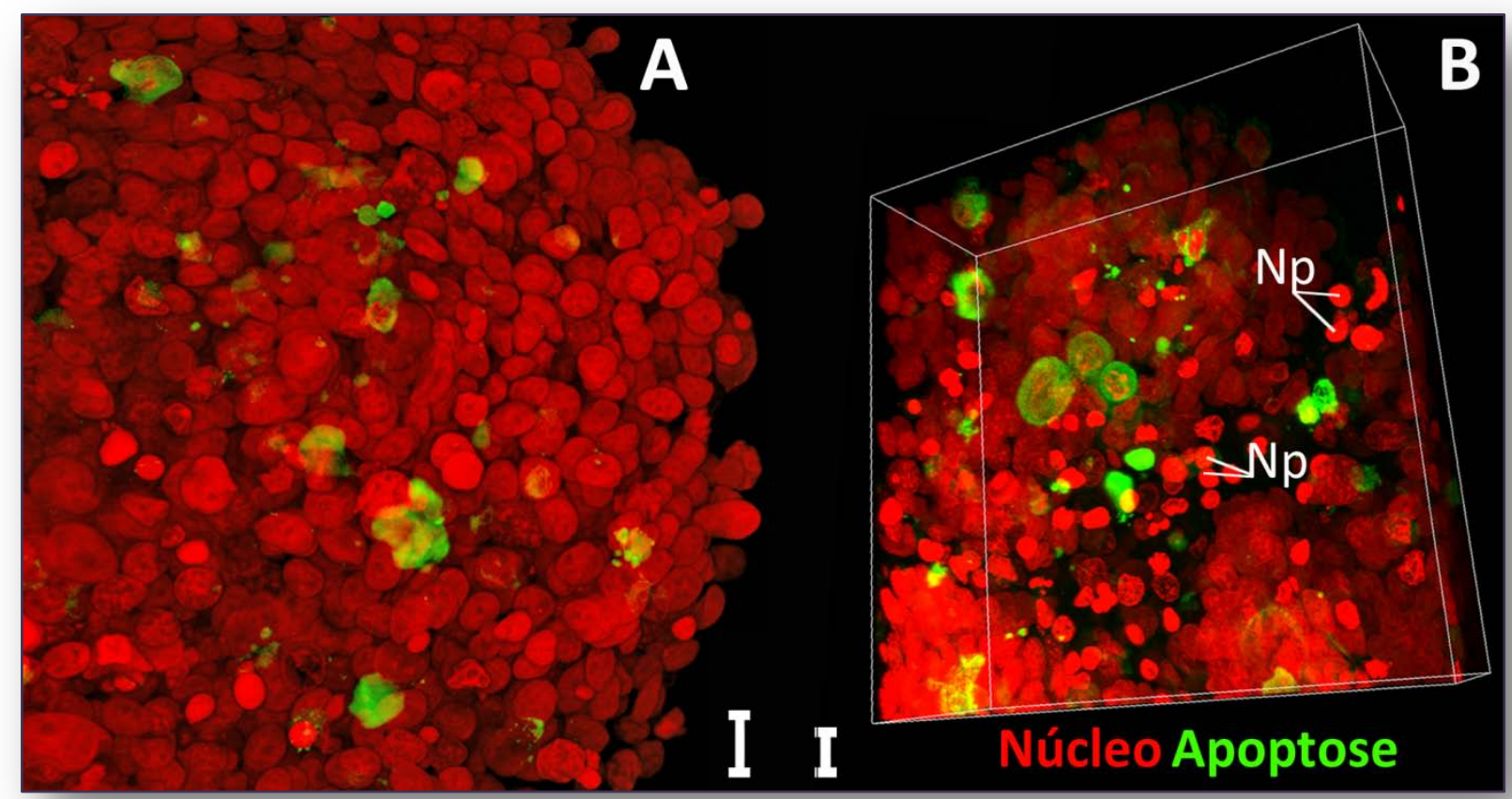

Figura 22 - Esferóides de células MCF-7 com 30 dias (A) e 115 dias de cultura (B) marcados pela técnica de M30. Notar a elevada presença de células com núcleos picnóticos (Np) em B. A marcação nuclear foi feita utilizando o corante fluorescente iodeto de propídeo. Reconstruções obtidas ao microscópio confocal de varredura a laser, sendo os resultados também analisados no software Imaris $7.1{ }^{\circledR}$. Barra $20 \mu \mathrm{m}$. 
4.4.2 O ensaio para a deteç̧ão de Caspase 9 por citometria de fluxo

Visando ainda ampliar o panorama de informações a respeito do papel da apoptose no sistema, optamos em paralelo ao estudo da clivagem da citoqueratina 18 analisar a expressão de uma Caspase iniciadora, a Caspase 9. O kit utilizado permitiu analisar o número de células viáveis, necróticas e células apoptóticas (com e sem integridade de membrana) em esferóides com diferentes tempos de cultura.

Os resultados mostrados com essa técnica confirmaram as descrições morfológicas prévias, as quais apontavam para a diminuição das células viáveis ao longo do tempo de cultura 3D em detrimento do aumento do número de células em processo de morte (ver Figura 23, 24 e Tabela 3). Todavia, foi notada uma existência de um padrão que aproximava os valores encontrados permitindo separá-los em 2 dois grupos; o 1 o constituído pelas células em monocamada e esferóides com 7 dias de cultura e o 2 으 grupo composto pelos esferóides com 30 e com 50 dias de cultura. Tanto o número de células apoptóticas quanto o de células necróticas foi mais elevado no segundo grupo de amostras, sendo sempre os resultados mais altos encontrados nos esferóides com 30 dias de cultura 3D. 


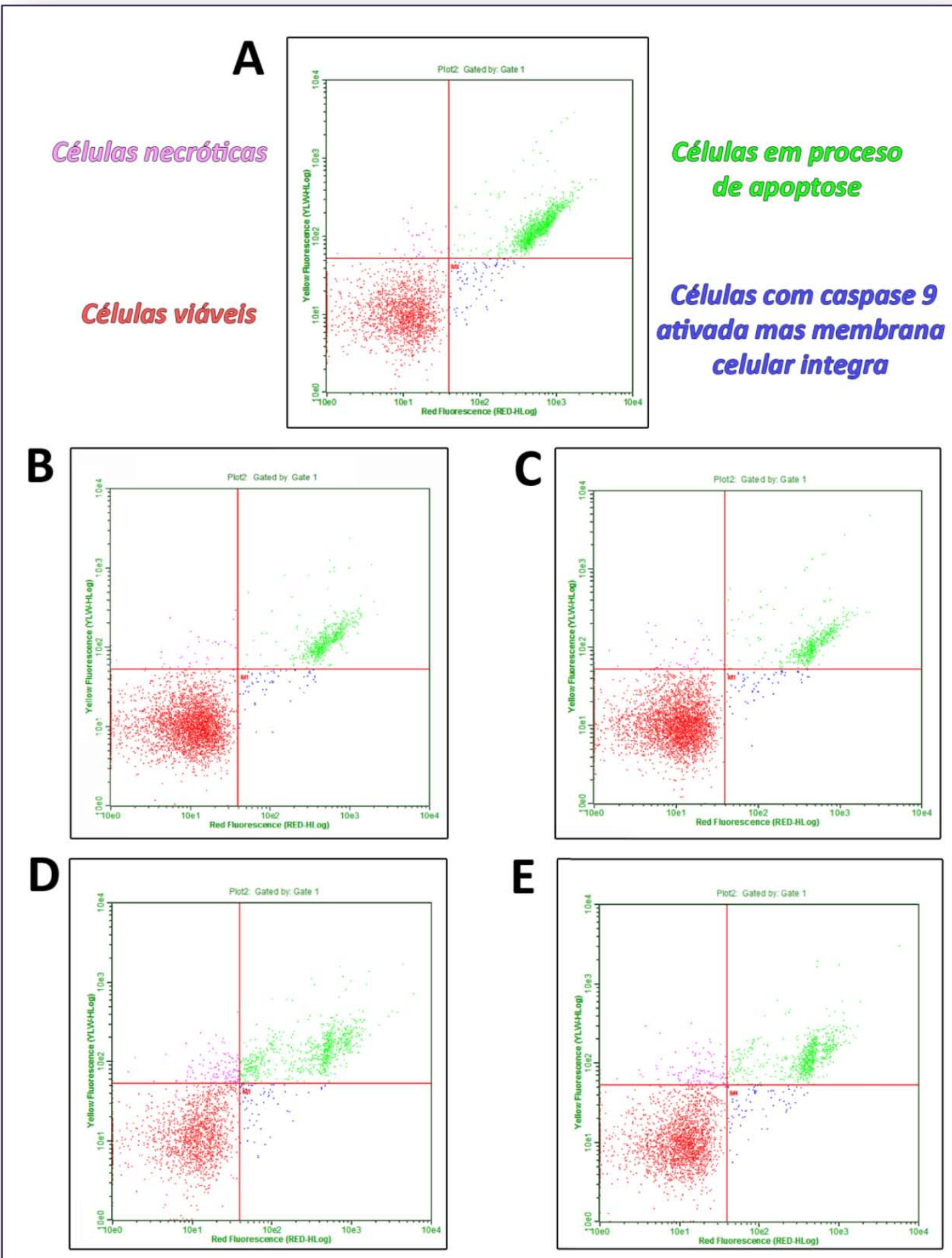

Figura 23 - Quantificação por citometria de fluxo de células em processo de morte celular usando Guava ${ }^{\circledR}$ Caspase 9 SR Kit. No quadrante inferior esquerdo células (-) para o reagente de caspase e (-) para 7-AAD. O quadrante inferior direito mostra células (+) para o reagente de caspase e (-) para 7-AAD. No quadrante superior direito células $(+)$ para o reagente de caspase e $(+)$ para 7AAD. Por fim, no quadrante superior esquerdo as células (-) para o reagente de caspase e (+) para 7-AAD. Células MCF-7 em monocamada foram tratadas com radiação ultravioleta e analisadas como controle positivo para apoptose (A). MCF-7 em monocamada (B), esferóide com 7 dias de cultura 3D (C), com 30 dias (D) e com 50 dias (E). 


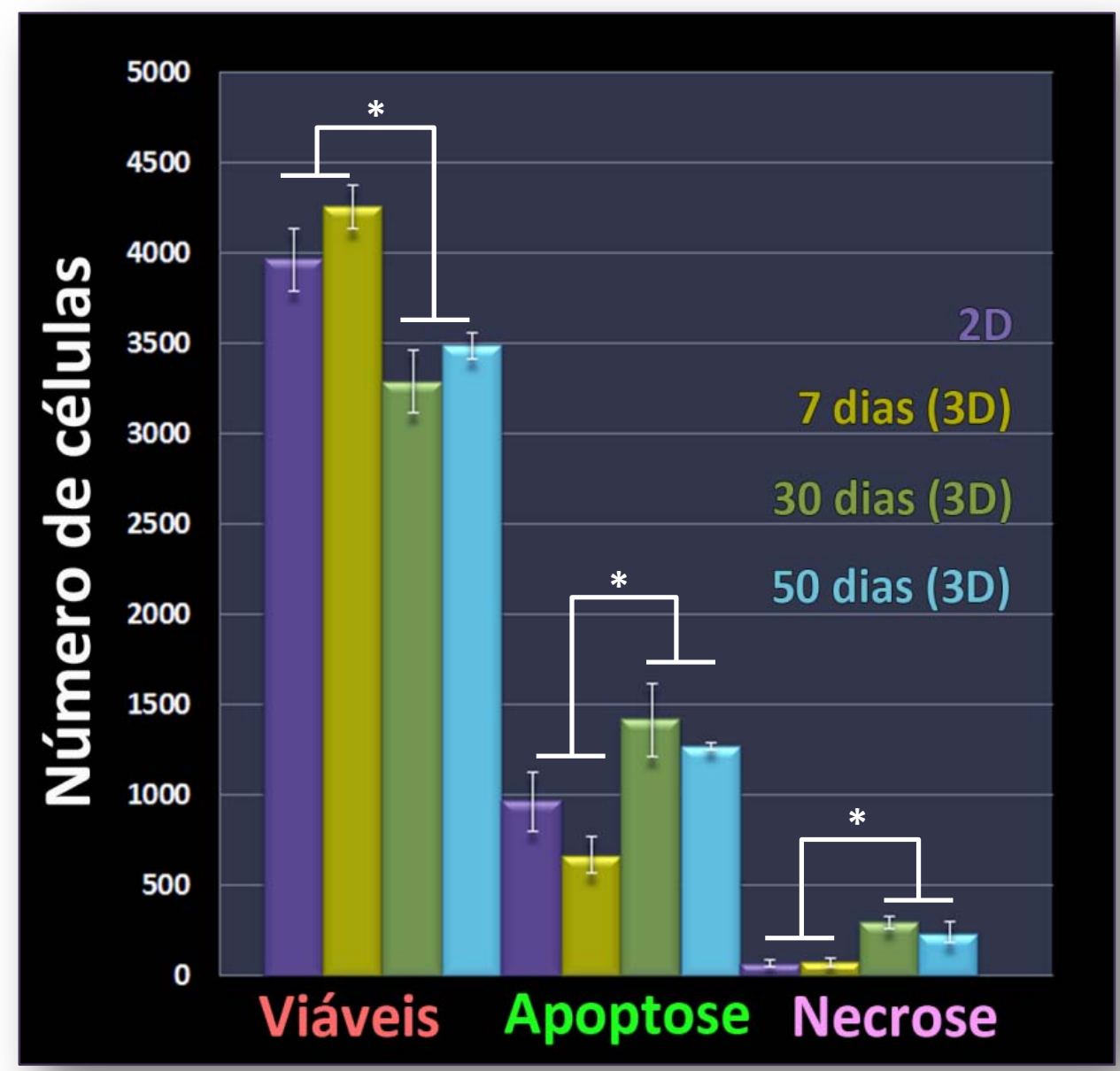

Figura 24 - Representação gráfica dos resultados apresentados em forma de dot plot (Figura 22).

$$
*=p<0,05
$$

Tabela 3 - Média e desvio padrão do número de células encontradas no ensaio de Caspase 9.

Células Viáveis

\begin{tabular}{cccc}
\hline 2D & 7 dias (3D) & 30 dias (3D) & 50 dias (3D) \\
\hline $3967 \pm 176$ & $4255 \pm 122$ & $3290 \pm 171$ & $3491 \pm 70$ \\
\hline
\end{tabular}

Células em Processo de Apoptose

\begin{tabular}{cccc}
\hline $2 \mathrm{D}$ & 7 dias (3D) & 30 dias (3D) & 50 dias (3D) \\
\hline $965 \pm 166$ & $669 \pm 102$ & $1417 \pm 201$ & $1270 \pm 18$ \\
\hline
\end{tabular}

Células em Processo de Necrose

\begin{tabular}{cccc}
\hline $2 \mathrm{D}$ & 7 dias (3D) & 30 dias (3D) & 50 dias (3D) \\
\hline $69 \pm 21$ & $76 \pm 25$ & $293 \pm 32$ & $239 \pm 56$ \\
\hline
\end{tabular}


Como descrito previamente por microscopia eletrônica, a autofagia é outro processo presente durante a formação da estrutura luminal. Devido a sua relação com a morte celular e com processos morfogênicos, a análise posterior teve como objetivo a quantificação da autofagia ao longo do tempo de cultura 3D, possibilitando assim a comparação deste processo com os observados para morte celular.

4.4.3 Quantificação do processo de autofagia nos esferóides

Devido a sua interação a processos relacionados à formação de autofagossomos, a proteína LC3B vem sendo cada vez mais utilizada como indicador de processos autofágicos. Nas células, essa proteína pode tanto apresentar-se na sua forma citoplasmática (LC3B-I) ou associada diretamente com a membrana plasmática dos autofagossomos (LC3B-II).

Os resultados obtidos por western blot mostraram que a expressão protéica da forma citoplasmática (LC3B-I) foi baixa em células crescidas em monocamada. Entretanto, ao se analisar a expressão desta proteína em ambiente 3D, verificou-se um crescente aumento de expressão ao longo do tempo de cultura. Já a forma associada aos autofagossomos (LC3-II), teve a sua expressão aumentada de maneira crescente desde a monocamada até esferóides com 30 dias de cultura (sendo este ponto o de maior intensidade de marcação). Após esta data, em 50 dias, houve uma significativa redução da expressão de LC3B-II (Figura 25B) nos esferóides analisados.

Como conseqüência desta primeira abordagem, esferóides com 30 dias de cultura foram marcados por imunofluorescência, sendo que a maior positividade a esta marcação ocorreu na região medular anteriormente a formação do espaço luminal (Figura 25A).

A diferença da expressão protéica ao longo do tempo e nos diferentes modos de cultivo (2DX3D) mostrou, primeiramente, um concomitante aumento de 3 processos fisiológicosautofagia, necrose e apoptose- em esferóides com 30 dias de cultura. Além disso, a somatória dos resultados obtidos mostrou que associado as alterações morfológicas algumas proteínas poderiam ser expressas diferentemente. A partir deste momento, o trabalho se concentrou em alterações na expressão de diferentes proteínas, fato este que será explorado a seguir. 


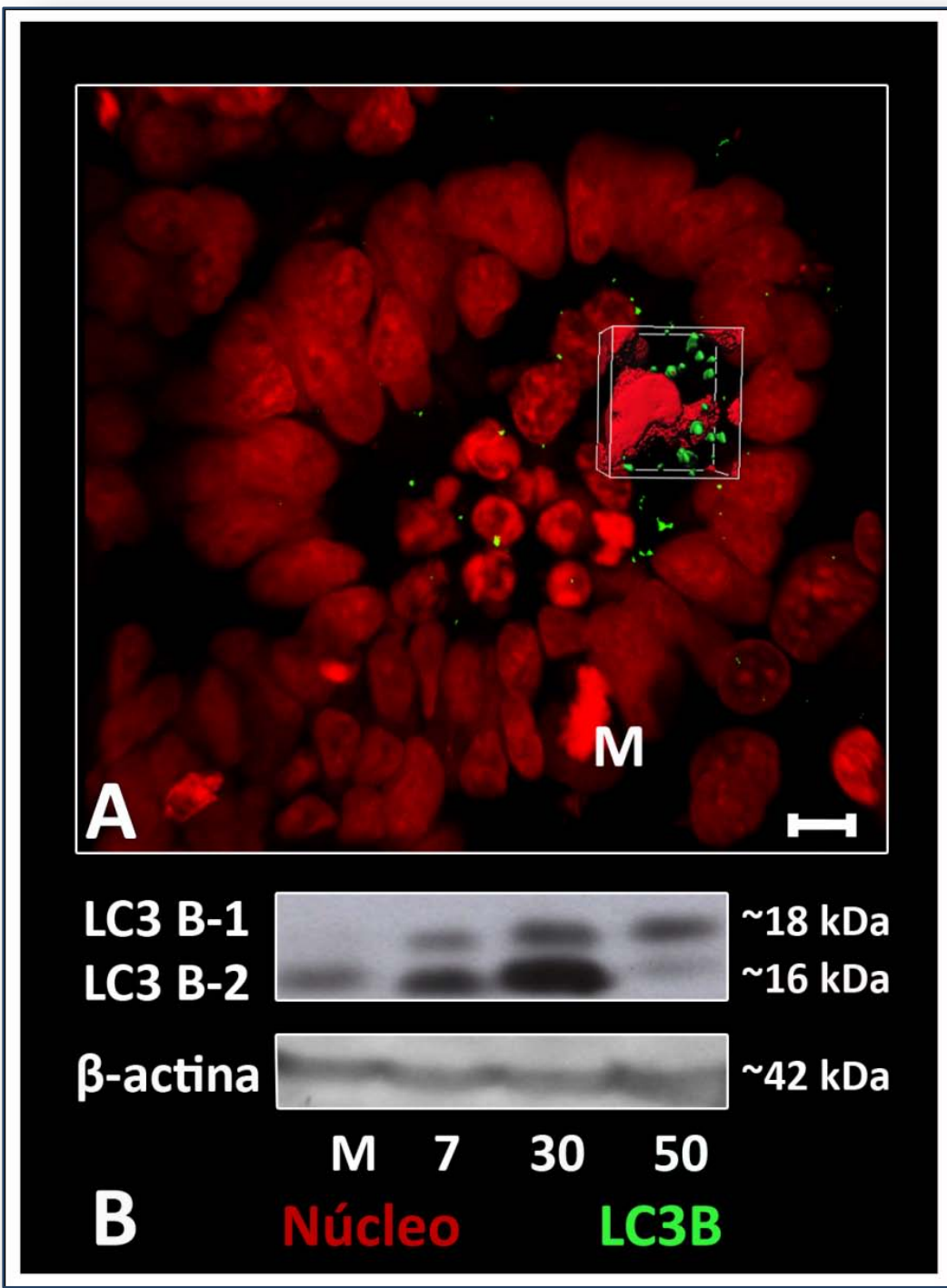

Figura 25 - Células MCF-7 crescidas em cultura 3D por 30 dias mostrando fase anterior a formação do espaço luminal (A). Notar positividade para a proteína LC3B na região medular (detalhe na reconstrução feita pelo software Imaris $\left.7 .{ }^{\circledR}\right)$. Imuno marcação feita com anti-LC3 e anti-IgG de coelho-FITC (mostrado em verde) e marcação nuclear feita com o corante fluorescente iodeto de propídeo (vermelho). As reconstruções foram obtidas ao microscópio confocal de varredura a laser. Barra $10 \mu \mathrm{m}$. A quantificação da expressão da proteína LC3B foi feita pela técnica de western blot (B). $M=$ monocamada, 7, 30, 50=dias de cultura 3D 


\subsection{A EXPRESSÃO E LOCALIZAÇÃO DE ALGUMAS PROTEÍNAS NA CULTURA 3D}

4.5.1 AKT fosforilada

Akt, é uma serina/treonina quinase a qual pode fazer mediação entre fatores de crescimento e sobrevivência celular. A expressão desta proteína em células crescidas em monocamada mostrou-se baixa quando comparada com células crescidas em 3D. Todavia, nas fases iniciais da cultura 3D, houve um elevado aumento de AKT fosforilada (p-AKT) (mostrado aqui com 7 dias de cultura), com posterior diminuição da sua expressão ao longo do tempo (com 30 e 50 dias, mostrados na Figura 26D).

Por imunofluorescência, observamos uma maior positividade para p-AKT nas células localizadas na região cortical de esferóides com 7 dias de cultura (Figura 26A-B). Nos outros pontos analisados, a intensidade da marcação mostrou-se menor (Figura 26C).

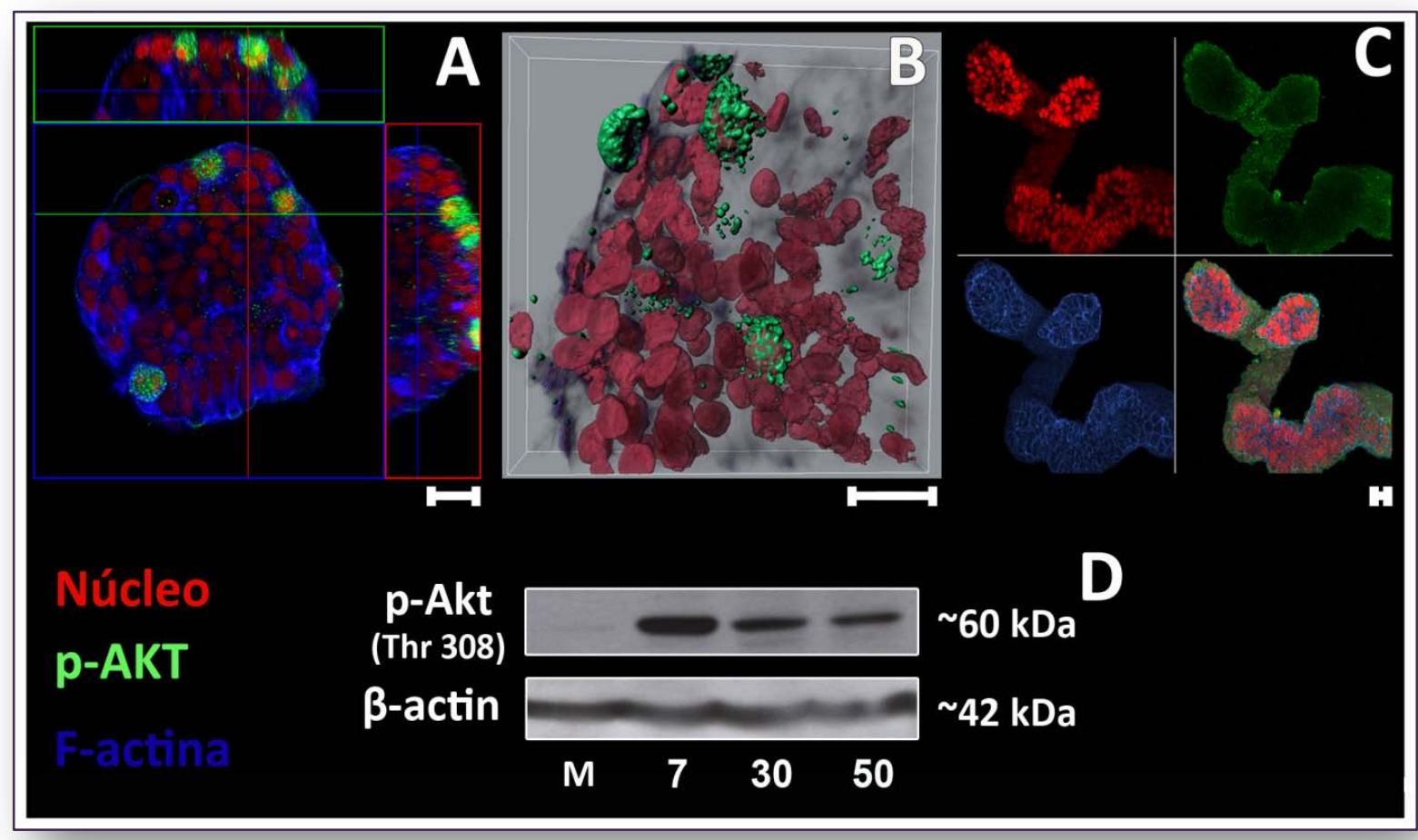

Figura 26 - Células MCF-7 crescidas em cultura 3D por 7 dias (A e B) e 50 dias(C). Notar marcação para pAKT na região cortical dos esferóides com 7 dias mostradas em conte ortogonal (A) e após tratamento para se obter volume (software Imaris $7.1^{\circledR}$ ) em B. Imuno-marcação feita com anti-p-AKT e anti IgG de coelho-FITC (mostrado em verde),marcação nuclear feita com o corante fluorescente iodeto de propídeo (vermelho) e faloidina-633 (azul). As reconstruções foram obtidas ao microscópio confocal de varredura a laser. Barra $20 \mu \mathrm{m}$. A quantificação da expressão da proteína p-AKT foi feita pela técnica de western blot (D). $\mathrm{M}=$ monocamada, $7,30,50=$ dias de cultura 3D 


\subsubsection{PAR 4 E ERK FOSFORILADA}

A expressão da proteína pró-apoptótica PAR-4 se manteve semelhante desde a monocamada até esferóides com 30 dias de cultura 3D. Já aos 50 dias de cultura foi possível observar uma maior marcação quando comparada com os pontos anteriores (Figura 27).

Já a proteína ERK fosforilada (tirosina 204), apresentou uma maior expressão na monocamada. Em ambiente 3D, as células dos esferóides diminuíram a expressão desta proteína ao longo do tempo, o qual culminou em uma baixa expressão nos esferóides com 50 dias de cultura (Figura 27).

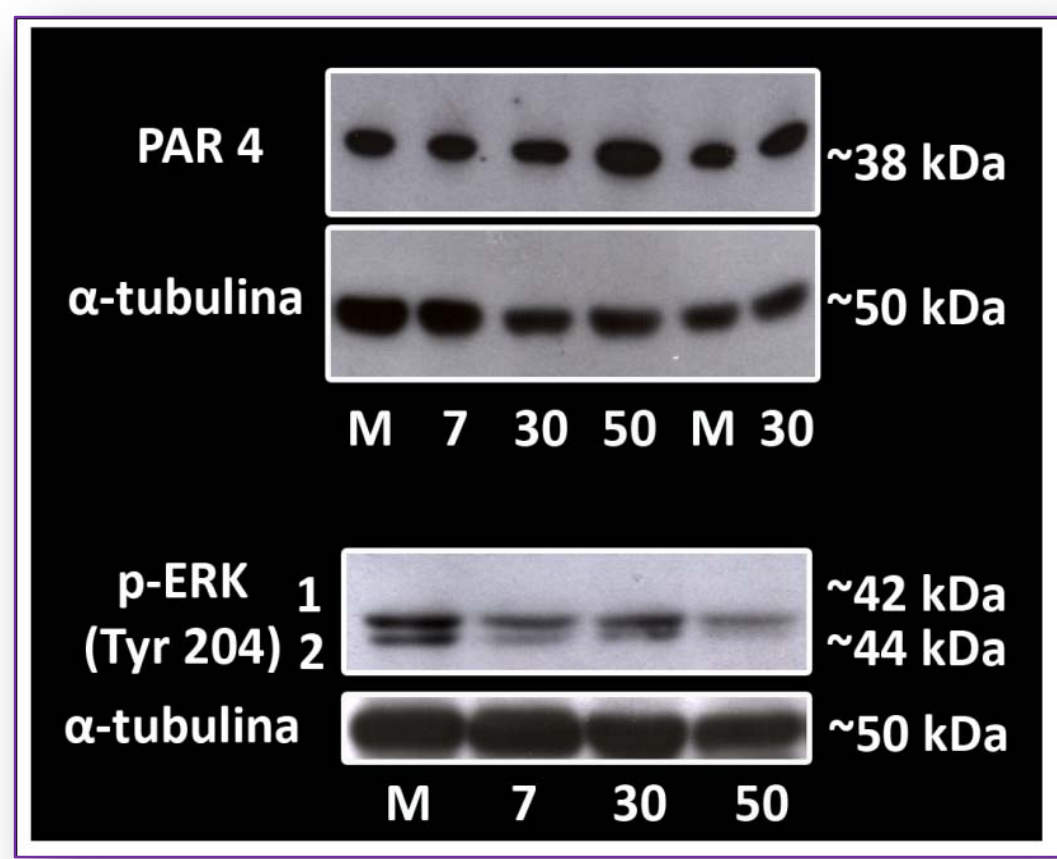

Figura 27 - Quantificação da expressão das proteínas PAR-4 e p-ERK pela técnica de western blot $\mathrm{M}=$ monocamada, $7,30,50=$ dias de cultura 3D

4.5.3 ADAMTS-1

A expressão desta metaloproteinase mostrou-se mais intensa na monocamada e nas fases inicias da cultura 3D (7 dias). Aos 30 dias e, principalmente aos 50 dias, foi possível observar uma diminuição desta expressão (Figura 28E). A análise por imunofluorescência mostrou uma intensa marcação desta proteína na região nuclear, sendo que nos esferóides essa marcação foi mais evidente na região do nucléolo. ADAMTS-1 também foi visualizado na 
superfície das células crescidas em monocamada, estando este padrão ausente em ambiente 3D (compare Figura 28B com 28D).

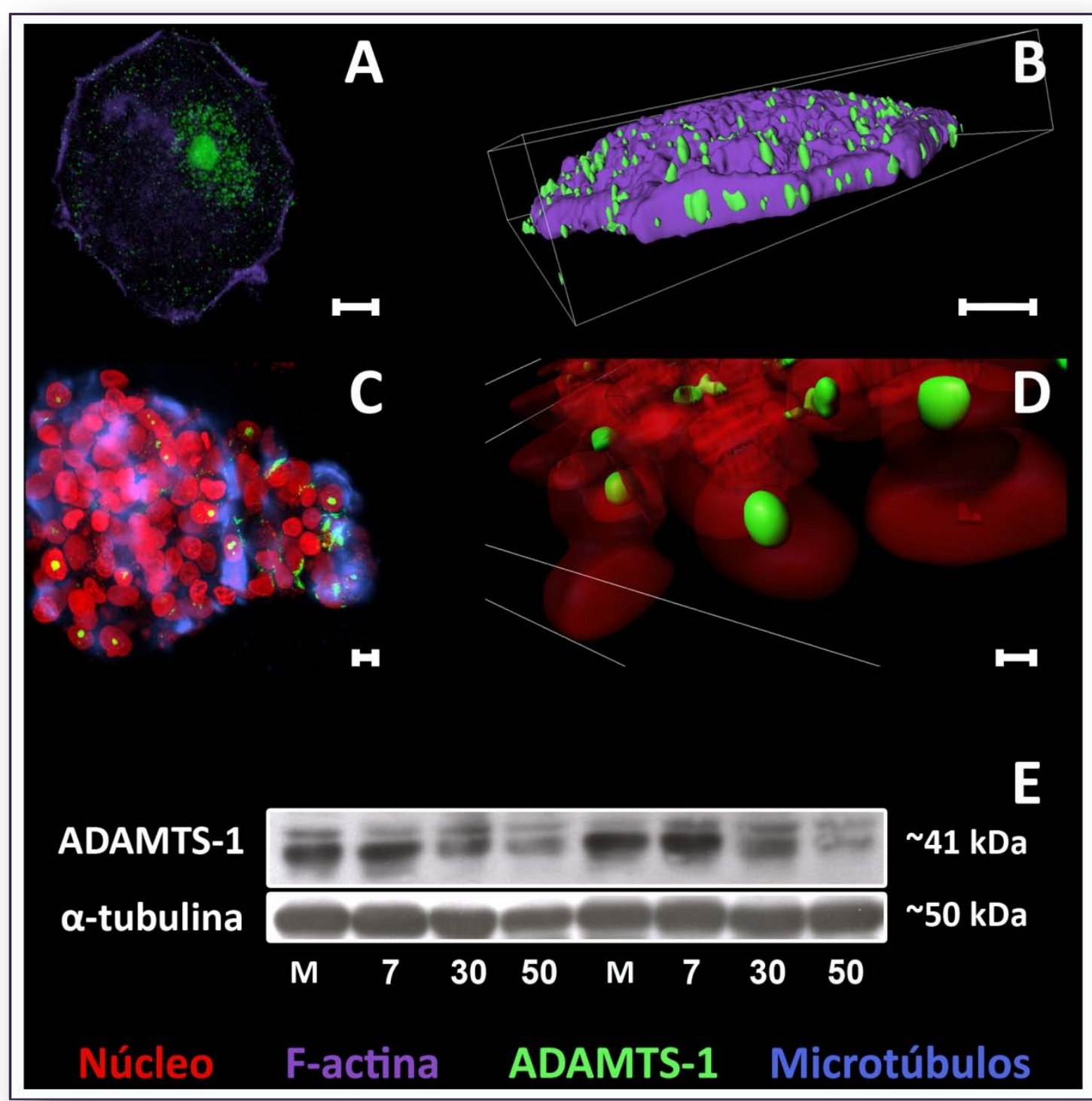

Figura 28 - Células MCF-7 mostradas aqui quando arranjadas em monocamada (A e B) e em 30 dias de cultura 3D (C e D). A marcação da proteína ADAMTS-1 (em verde) mostrou-se intensa na região nuclear, sendo que na monocamada tal marcação foi também acompanhada de pontuações na membrana celular (evidenciadas na reconstrução mostrada em B). Reconstruções obtidas ao microscópio confocal de varredura a laser, obtendo o volume destas utilizando o software IMARIS ${ }^{\circledR} 7.1$ (B e D). Imunomarcação feita com anti ADAMTS-1 e anti-igG de coelho acoplado a FITC. Foram também utilizados os corantes fluorescentes iodeto de propídeo para a marcação nuclear e faloidina-TRITC para os microfilamentos de Factina. Barra $10 \mu \mathrm{m}$. A quantificação da expressão de ADAMTS-1 foi feita pela técnica de western blot (E). M=monocamada, 7, 30, 50=dias de cultura 3D. 
Até então, todos os experimentos descritos previamente indicaram a existência de diferenças entre os pontos até então analisados. Seguindo esta linha, resolvemos verificar a possibilidade de alterações relacionadas ao ciclo celular, fato este explorado no próximo item.

\subsection{PLOIDIA/CICLO CELULAR}

Novamente nossa análise focou os pontos onde, na cultura 3D, foram verificados as maiores alterações morfológicas. Assim, monocamada e esferóides com 7, 30 e 50 dias de cultura foram analisados por citometria de fluxo sendo o DNA das células corado com iodeto de propídeo (todos os resultados descritos nesta sessão estão representados na Figura 29 e na Tabela 4)

A população hipodiplóide cresceu ao longo do tempo de cultura, todavia, quando comparada com os resultados obtidos em monocamada, foi observado que o número de células nessa classe ploidia era maior na monocamada do que em esferóides com 7 dias.

A porcentagem de células que se encontravam na fase $\mathrm{G} 1$ do ciclo aumentou significantemente na mudança do ambiente 2D para 3D. Entretanto, no decorrer do tempo de cultura 3D a porcentagem do número de células em G1 se manteve muito próxima.

A maior porcentagem de células na fase $S$ foi descrita nas células crescidas em monocamada. Já em ambiente 3D, foi possível visualizar uma diminuição desta fase principalmente em 30 dias de cultura.

A análise da fase G2-M nos pontos estudados apontou para uma diminuição da porcentagem de células nesta fase sendo esta fase maior no ambiente em monocamada, com uma diminuição progressiva à medida que avança o tempo de cultura 3D.

Os resultados também mostraram que a freqüência do número de células com ploidia igual ou maior que $5 \mathrm{C}$ (hipertetraplóides) diminuiu de forma bem significativa quando as células crescidas em monocamada passam a ser mantidas em ambiente 3D.

Com este último experimento foi possível traçar um panorama das diferenças existentes entre as células crescidas em monocamada e em ambiente 3D. Diante disso e da viabilidade do método, surgiu uma nova questão. Seria possível selecionar esses esferóides diferenciados? 
Quando colocados novamente para crescer em monocamada, o que poderia ocorrer? Tais questionamentos levaram então a série de experimentos mostrados a seguir.

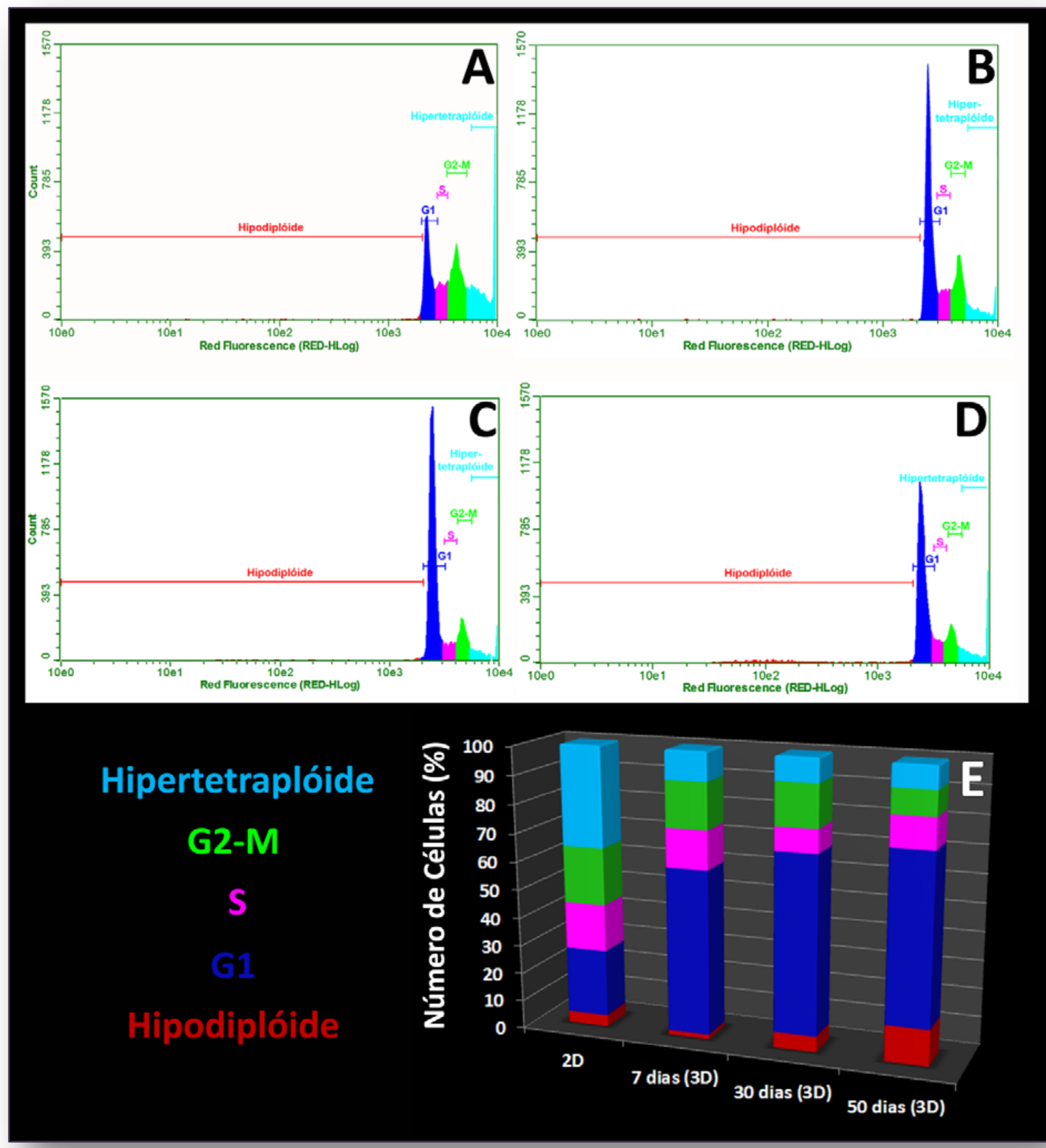

Figura 29 - A legenda desta prancha está localizada no verso da página ao lado. 
Tabela 4 - Média e desvio padrão do número de células encontradas no ensaio de ploidia/ciclo celular. Os números marcados em verde não apresentaram diferenças significativas entre eles (comparar na mesma população de célula).

\begin{tabular}{ccccc}
\hline & 2D & 7dias (3D) & 30 dias (3D) & 50 dias (3D) \\
\hline Hipodiplóide & $4,06 \pm 0,69$ & $1,61 \pm 0,19$ & $5,65 \pm 1,58$ & $12,78 \pm 1,54$ \\
G1 & $23,67 \pm 2,08$ & $58,14 \pm 2,21$ & $62,80 \pm 2,61$ & $59,72 \pm 1,04$ \\
S & $16,59 \pm 0,89$ & $13,76 \pm 0,63$ & $8,22 \pm 1,19$ & $10,65 \pm 0,88$ \\
G2-M & $20,20 \pm 0,81$ & $16,29 \pm 2,01$ & $14,96 \pm 1,34$ & $8,71 \pm 0,17$ \\
Hipertetraplóide & $35,48 \pm 3,94$ & $10,24 \pm 0,36$ & $8,36 \pm 0,49$ & $7,84 \pm 1,41$ \\
\hline
\end{tabular}

\subsection{SELEÇÃO DAS CÉLULAS CRESCIDAS EM CULTURA 3D E A MANUTENÇÃO DE UMA NOVA LINHAGEM}

Para manter uma homogeneidade no que se refere à população de esferóides com aspecto tubular e acinar, optamos por coletar esferóides diferenciados (após 50 dias de cultura 3D) (Figura 7D) e retorná-los ao crescimento em monocamada. Para tanto, em uma primeira abordagem, as células em suspensão resultantes da dissociação dos esferóides foram colocadas para crescer em garrafas de cultivo de tecido (Figura 30). A morfologia destas células, quando analisadas por meio de microscopia de contraste de fase, mostrou-se muito semelhante aos resultados encontrados para a linhagem MCF-7 (Figura 30A-C, com 0, 3 e 5 dias de cultura respectivamente). Posteriormente a essa descrição, novamente foram analisados a organização dos microfilamentos de actina e os microtúbulos deste retorno das células a monocamada. Não foram observadas diferenças significativas na morfologia destes componentes comparando a linhagem derivada de esferóides com linhagens MCF-7 (Figuras 30D-F). Em algumas células, entretanto, foi observada a formação de vacúolos os quais, em alguns casos, se mostraram positivos para faloidina-FITC (Figura 30F).

A segunda abordagem metodológica consistiu em colocar os esferóides diferenciados após 50 dias de cultura 3D (Figura 31A) diretamente nos frascos de cultivo. Já nas primeiras 24 horas as células destes esferóides apresentaram forte adesão à superfície (Figura 31 B e C). Após isso, ao longo do tempo de cultura, foi observado uma crescente migração destas células a qual se iniciou marginalmente aos esferóides (Figura 31D e E com 2 e 3 dias respectivamente) assumindo um posterior direcionamento radial ao seu redor (Figura 31F e G após 4 dias). Neste 
processo, ficou evidente a gradual diminuição de células arranjadas em 3D em detrimento do espraiamento e aumento de migração destas células. Cortes ortogonais de reconstruções obtidas ao microscópio confocal de varredura a laser possibilitaram a análise desta transição da cultura 3D para monocamada (Figura 31G). 


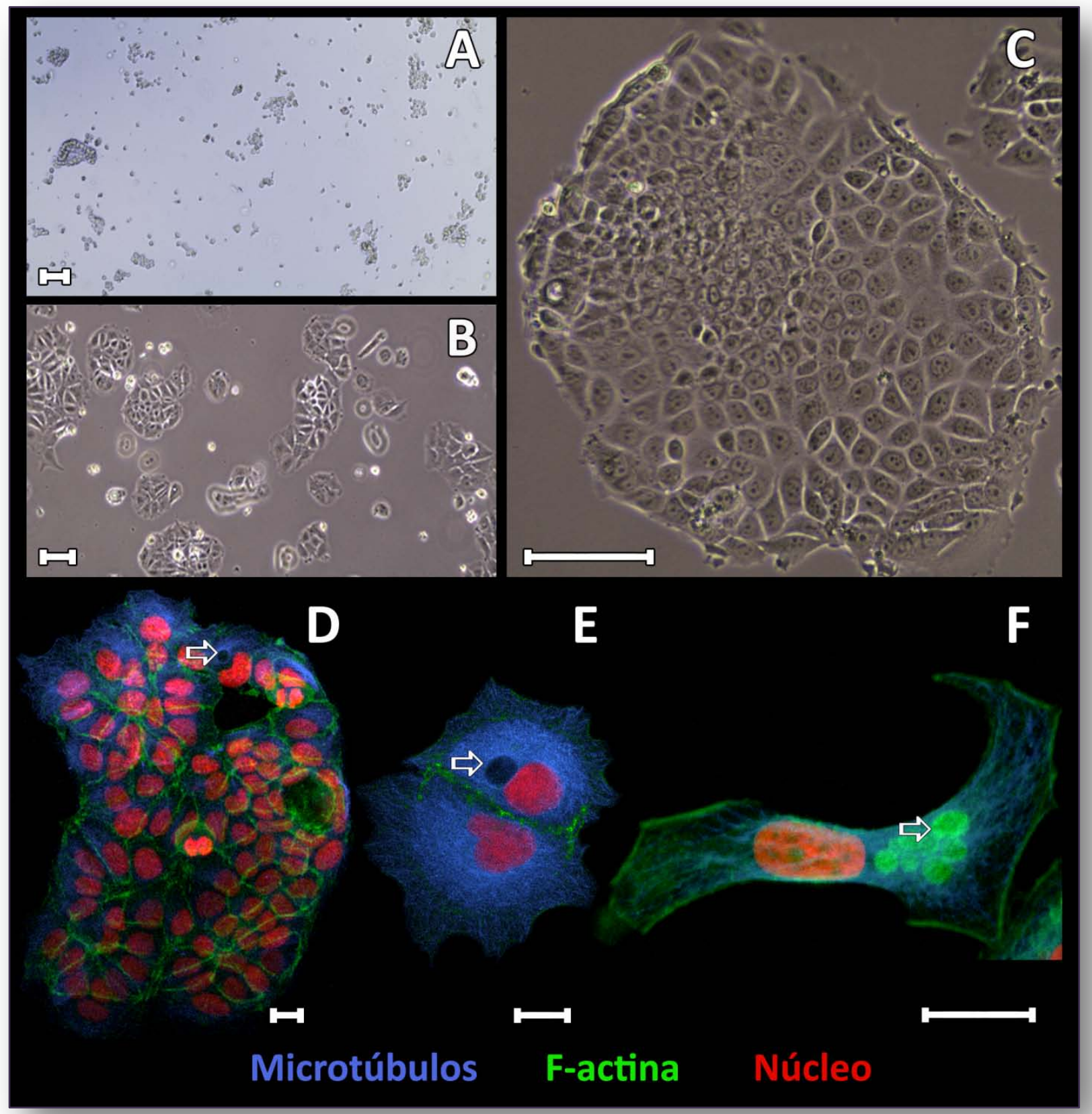

Figura 30 - Após serem mantidas em cultura 3D por 50 dias, os esferóides de células MCF-7 foram dissociados (A) e as células colocadas para crescer arranjadas em monocamada, as quais mostradas aqui com 1 dia de cultura (B) 3 dias (C) e 5 dias (D-F). Foi observada em algumas células a presença vacúolos (seta). Imagens obtidas por microscopia de luz de campo claro (A) e com contraste de fase ( $B$ e C). As imagens $D$, E e F foram obtidas ao microscópio confocal de varredura a laser. Foram utilizados os corantes fluorescentes lodeto de propídeo (vermelho) e faloidina-FITC (verde). Em azul foram utilizados anticorpo anti $\alpha$ e anti $\beta$ tubulina, sendo posteriormente marcados com anti-lgG de camundongo conjugado com CY5. Barra A, B e C $100 \mu \mathrm{m} ; \mathrm{D}, \mathrm{E}$ e F $=20 \mu \mathrm{m}$ 


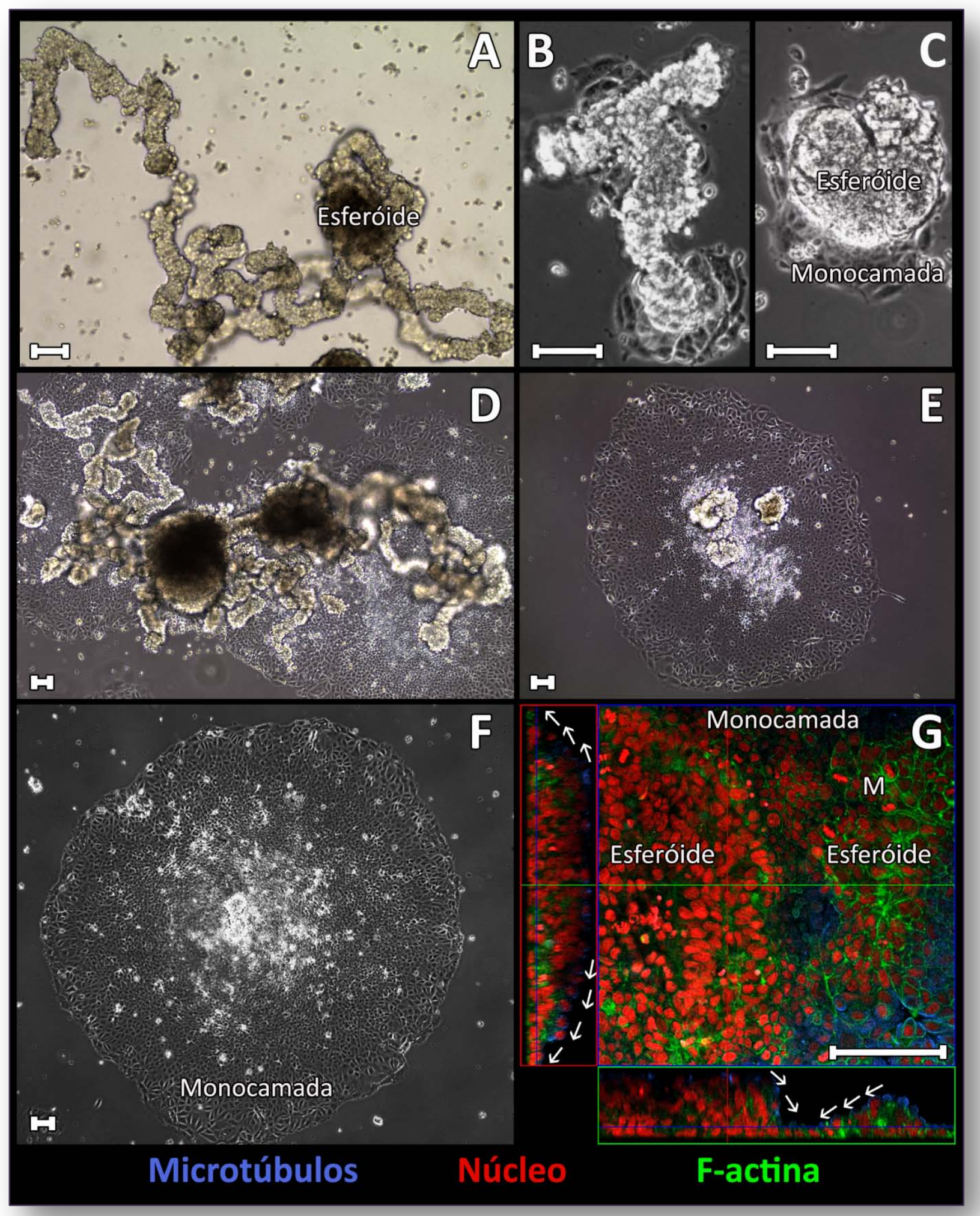

Figura 31 - A legenda desta prancha está localizada no verso da página ao lado 
Após o estabelecimento das células crescidas em monocamada, estas passaram novamente pelo processo de formação de esferóide em cultura 3D. As células em suspensão agruparam-se de maneira semelhante ao já descrito para formação de esferóides, isto é, assumiram um crescente arranjo esférico decorrente da maior interação entre as células. $\mathrm{Na}$ Figura 32, foi possível acompanhar essa fase formação desde as células em suspensão (Figura 32 A) até esferóides com 2 e 5 dias (Figuras 32B e C, respectivamente). Posterior a essa data, foi observado alterações na morfologia que apontavam para a diferenciação, o qual podemos citar como exemplo o crescente aumento dos brotamentos corticais.

Ao redor de 15 dias ficou evidente que o processo de seleção dos esferóides diferenciados foi bastante eficiente, haja visto que nesta fase foram descritos uma população de esferóides tubulares muito grande (Figura 32D). Além da presença de diferenciação (Figuras 32 E, F G e H), foram observados esferóides arranjados em forma de ácino (Figura 32F).

Analisados por mais 10 dias, totalizando 25 dias de cultura 3D, os esferóides resultantes deste processo de seleção (Figura 33A e B) apresentaram morfologia muito semelhante ao dos esferóides com 50 dias usados para a formação da linhagem. Eles foram analisados por meio de microscopia confocal de varredura a laser, com o objetivo de verificar o a disposição dos microfilamentos de actina bem como a formação do arranjo luminal. A Figura 33C, mostra esferóides arranjados de forma tubular, onde é possível observar a maior concentração dos microfilamentos de actina no espaço luminal. A análise de reconstruções destes esferóides (Figura 33E) mostrou a também existência da formação de uma monocamada margeando espaço luminal tanto na porção tubular (Figura 33D) quanto na porção acinar (Figura 33F), esta que mostrou-se bastante desenvolvida. 


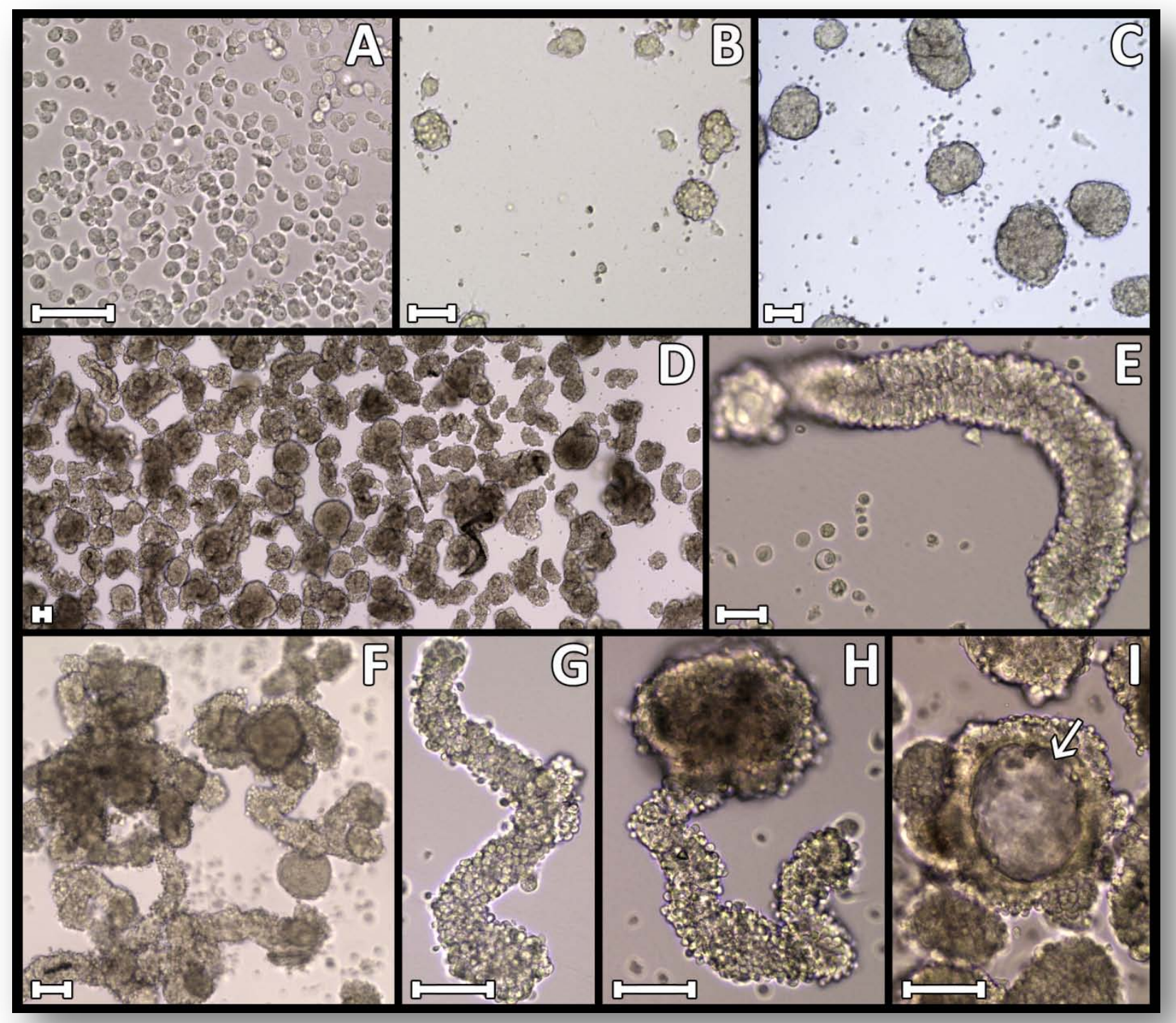

Figura 32 -Após dissociação por tripsina (A) as células MCF-7 selecionadas voltam a assumir a forma de esferóide quando em cultura 3D (B com 2 dias e $C$ com 5 dias). Nestas células já foi possível observar grande número de esferóides tubulares ao redor de 15 dias de cultura (D e mostrado em detalhe em E). Ao redor do 20 o dia de cultura observou-se o aumento do arranjo tubular ( $\mathrm{F}, \mathrm{G}$ e H) sendo possível em alguns esferóides visualizar o arranjo acinar (seta em I). Imagens obtidas ao microscópio de luz com campo claro. Barra $100 \mu \mathrm{m}$ 


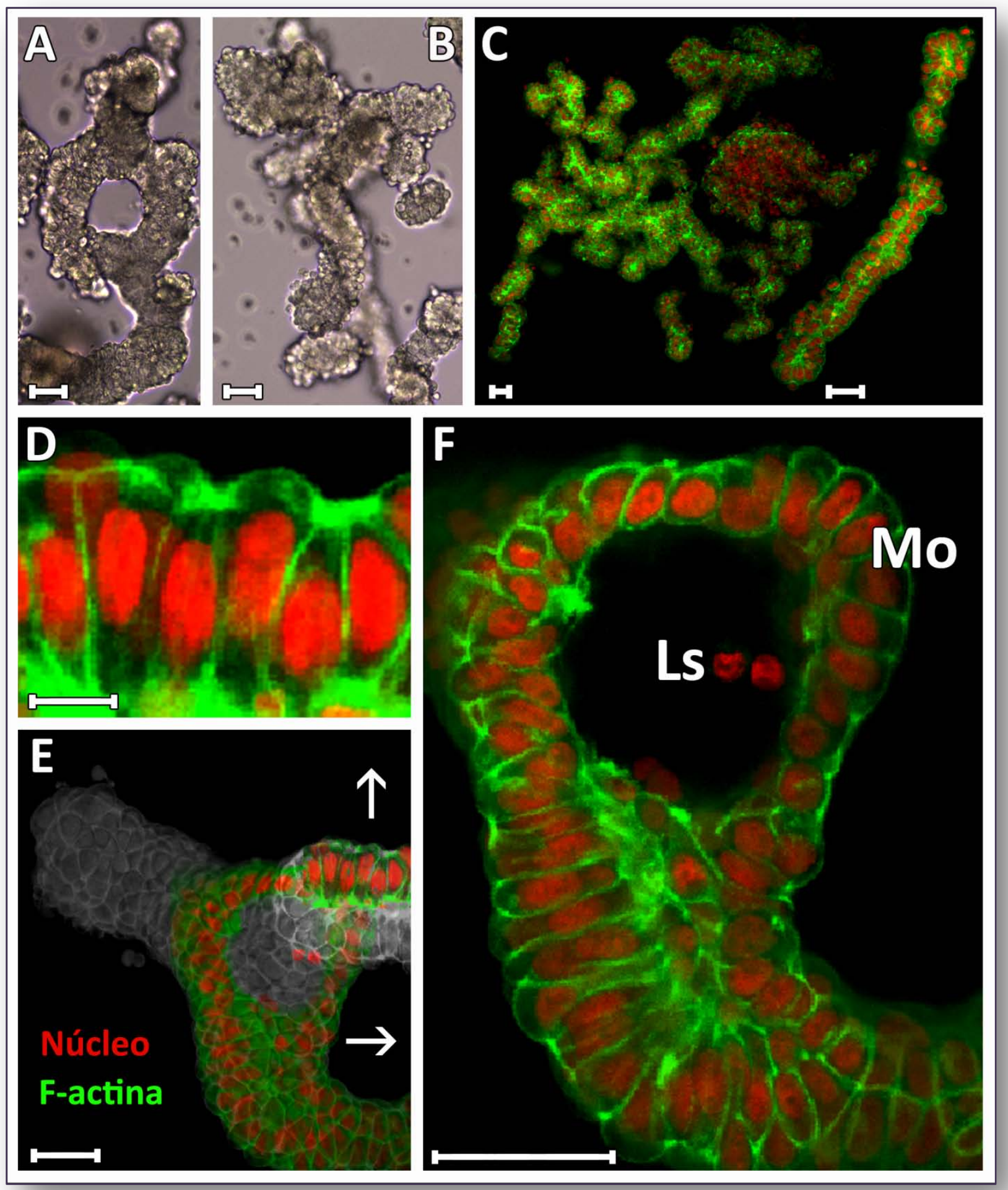

Figura 33 - A legenda desta prancha está localizada no verso da página ao lado. 


\subsection{EXPRESSÃO DE RNAM PARA E-CADERINA}

A proteína E-caderina possui importante papel em processos relacionados a interações célula-célula. Devido a isso, tornou-se necessário verificar se a mensagem para a síntese desta proteína estava sendo expressa em esferóides de células MCF-7. Tendo como referencia a cultura em monocamada, que se padronizou como expressão relativa igual a 1 , foi observado

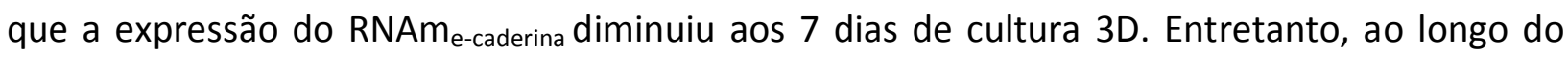
tempo, foi observado uma crescente na expressão sendo esta, em média, $60 \%$ mais expressa aos 50 dias de cultura 3D (quando comparada com monocamada). Um fato interessante foi que nos esferóides derivados do processo de seleção (ver seção 4.7) a expressão do RNAme-caderina foi em média $173 \%$ maior. Deve-se lembrar que as células que constituem estes esferóides passaram por uma fase em monocamada (2D), retornado posteriormente a cultura 3D. Desta maneira, podemos inferir que células que expressam mais E-caderina são mais selecionadas durante este processo.

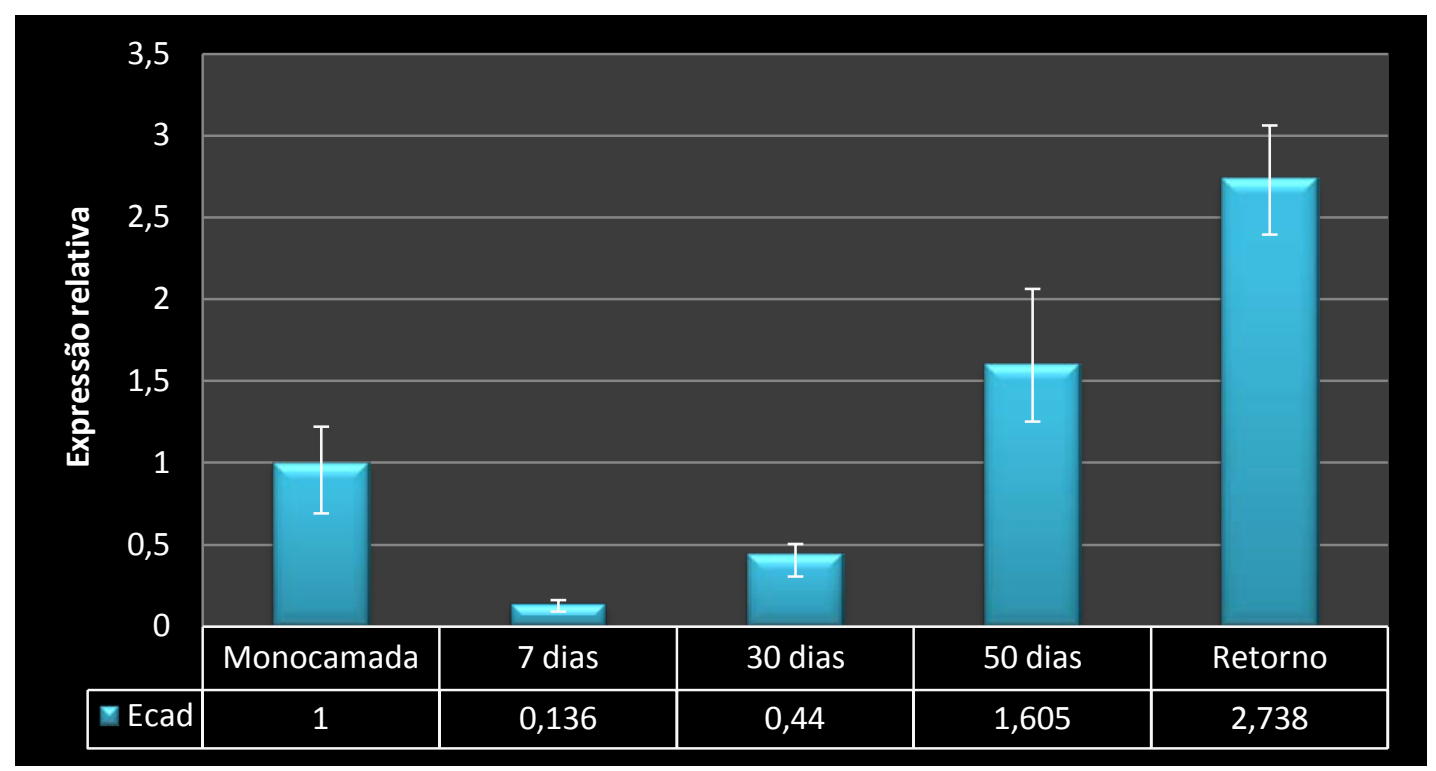

Figura 34 - Expressão relativa de RNAm para E-caderina em monocamada e em diferentes tempos de cultura 3D. A última coluna (retorno) se refere aos esferóides derivados da linhagem MCF-7 selecionada de esferóides já diferenciados. Todos os valores tiveram um $p<0,05$. 


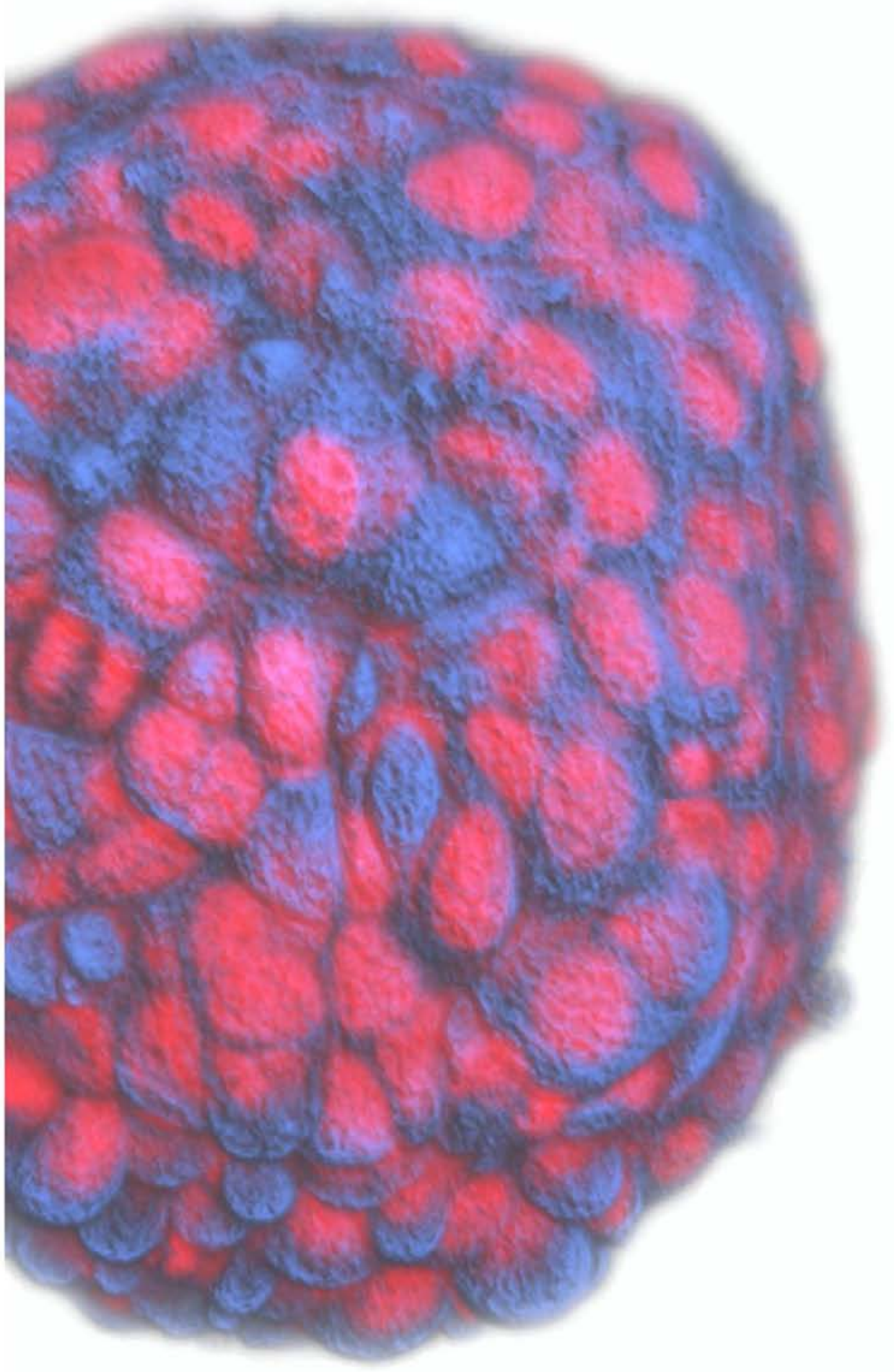

5_DISCUSSÃO 


\subsection{MODELOS E PARADIGMAS}

O desenvolvimento de estruturas luminais no decorrer da organogênese epitelial apresenta-se como essencial tanto na formação dos diferentes tipos de vasos em um organismo bem como e na gênese de órgãos como pâncreas, pulmões e as glândulas mamárias $(120,121)$. Essa complexidade intrínseca à morfogênese luminal de tecidos mamários decorre de uma íntima relação entre células epiteliais e o seu microambiente. A reprodução e análise deste processo in vitro mostram-se um desafio devido a diferentes vias regulatórias atuarem na formação do lúmen.

Como já mostrado, a linhagem MCF-10A (derivada de tecido mamário normal) vem se mostrando como modelo padrão no que se refere a estudos in vitro voltados a formação luminal $(71,122,123)$. Na maioria dos trabalhos que envolvem esferóides desta linhagem, a adição de Matrigel ${ }^{\circledR}$ insere-se neste sistema como um mimetizador de membrana basal. A conseqüência de tal método propiciou, principalmente após experimentos de Petersen e Weaver $(80,82)$, o desenvolvimento de estudos que relacionassem a influência do Matrigel ${ }^{\circledR}$ na formação luminal bem como tumorigênese. Os resultados apresentados nesta tese apontam, pela primeira vez na literatura, que a convergência de três diferentes características-linhagem MCF-7, maior tempo de cultivo 3D e a não suplementação com Matrigel ${ }^{\circledR}$-podem produzir esferóides diferenciados (Figura 35).

A gradual perda da polarização celular é um dos indicativos de alterações neoplásicas em tecidos mamários $(124,125)$. Deste modo, é de se esperar que modificações celulares que levem a formação de um espaço luminal sejam diferentemente manifestadas em linhagens MCF-7. Tal fato ocorre devido esta linhagem ser derivada de metástase de carcinoma ductal invasivo $(94,126)$, condição que a diferenciaria, e muito, de um tecido normal.

Células MCF-7 em ambiente 3D com Matrigel ${ }^{\circledR}$ rapidamente se organizam em esferóides com fortes interações célula-célula. Esse arranjo em forma de massa de células (segundo classificação sugerida por Kenny et al. (72) não sofre o processo de cavitação, isto é, não apresenta a formação de lúmen decorrente da morte das células localizadas na região medular. Tal morfologia não é alterada mesmo quando os esferóides desta linhagem são submetidos a diferentes substratos como polissacarídeos (quitosana) e polímeros (ácido polilactico) $(127,128)$. 


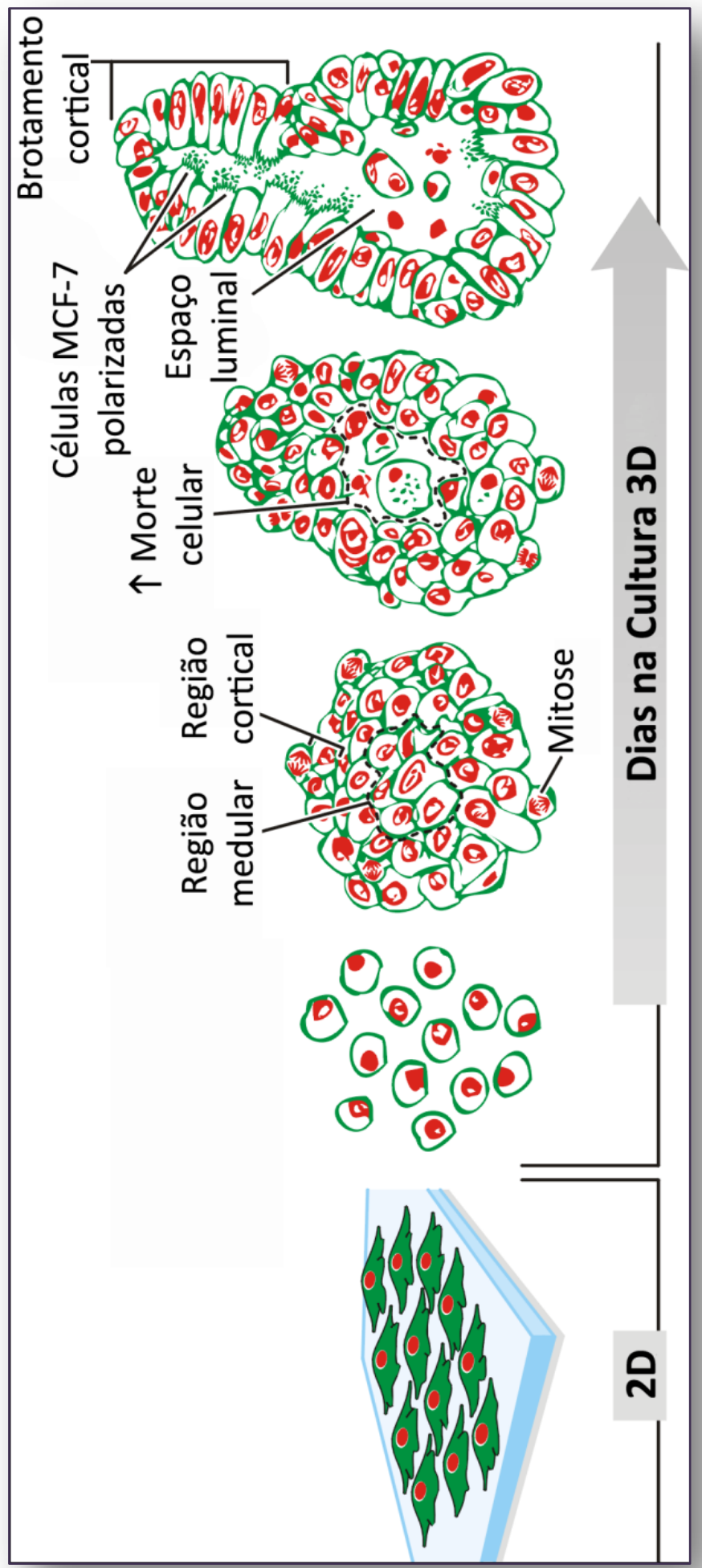

Figura 35 - Esquema mostrando as alterações na morfologia de esferóides de células MCF-7 decorrente do método de cultura em 3D proposto neste trabalho. 
Em 2003, Kirshner e colaboradores (97) trabalhavam com uma glicoproteína transmembrânica de adesão célula-célula denominada de CEACAM1 (carcinoembryonic antigen-related cell adhesion molecule 1). Devido essa glicoproteína ser constitutivamente expressa em células normais, este grupo então transfectou o gene que a codifica em células MCF-7 e observou quais seriam as alterações na morfologia. Diferentemente do até então descrito na literatura, os esferóides de células MCF-7 transfectadas quando em contato com Matrigel ${ }^{\circledR}$ formavam lúmen de maneira semelhante ao descrito para MCF-10A. Recentemente Chen e colaboradores (129), utilizando-se deste mesmo método conseguiram uma eficiência de até 95\% de esferóides com arranjo luminal em culturas de células MCF-7.

Por fim, a formação de lúmen na linhagem MCF-7 também foi obtida em um sistema de co-cultura. Krause et al.(98) desenvolveram um sistema que era constituído por uma cultura primária de fibroblastos, células MCF-7 e uma mistura de Matrigel ${ }^{\circledR}+$ colágeno tipo I. Outro fator importante foi o tempo de cultura deste experimento, o qual se estendeu por até 6 semanas.

A leitura dos resultados acima nos leva a comparar os diferentes modelos com os resultados apresentados neste presente trabalho. Como já foi mostrado, a forma de cultivo 3D desenvolvida por nosso grupo não somente permitiu esferóides com arranjo acinar, mas também com arranjos tubulares. Tal fato aponta para o envolvimento tanto do processo de cavitação, quanto de brotamento na formação de estruturas luminais (120). Estas características foram somente compartilhadas com esferóides crescidos no modelo de cocultura (98).

Diversos fatores podem atuar no processo de seleção de populações celulares dentro de linhagens já estabelecidas $(126,130)$. A cultura em 3-dimensões, neste contexto, mostra-se também como um fator de pressão de seleção por favorecer a proliferação de células fracamente responsivas a sinalização para anoikis. Deste modo, podemos inferir que nas fases iniciais do crescimento dos esferóides, algumas populações de células MCF-7 foram as que melhor se adequaram a perda de adesão com o substrato. Apesar de estabelecida desde a década de 70 , um crescente número de trabalhos vem mostrando a existência de diferentes sub-populações celulares na linhagem MCF-7. Um exemplo bastante estudado recentemente é a presença de células tronco em linhagens derivadas de tecidos mamários. Em populações tumorais, a pequena fração de células tronco é caracterizada pelo fenótipo $C D 44^{+}$e CD24- o qual permite a separação destas células por citometria $(131,132)$. Quando separadas do 
restante da população, as células tronco se arranjam em pequenos agregados denominados de mamosferas, os quais tem se mostrado muito mais resistente aos tratamentos quimioterápicos e radioterápicos (133). Essa heterogeneidade celular também pode estar associada à formação de lúmen encontrada em nosso trabalho. Os resultados apresentados aqui apontam para a possibilidade de que algumas populações celulares estariam, mesmo em um contexto de linhagem tumoral, direcionadas a reversão deste fenótipo. Alguns aspectos devem ser enfatizados a respeito deste assunto:

\section{O surgimento e manutenção da morfologia polarizada nas células}

A estabilização e manutenção de domínios na membrana plasmática são essenciais para funções celulares e desenvolvimento dos organismos. Neste contexto, a morfologia celular polarizada permite uma distribuição assimétrica de moléculas biologicamente ativas como proteínas, RNAs bem como de organelas (134). Mostramos que ao longo da cultura em 3-Dimensões houve uma gradual formação de uma única camada de células ao redor de um lúmen. A morfologia característica para células polarizadas foi confirmada pela ultraestrutura e pela presença de uma maior concentração de microfilamentos de actina na região apical, fato este que correspondente ao encontrado em microvilosidades (135). Na superfície das células voltada para o meio de cultura (o que seria equivalente a região basal da célula) a maior intensidade de marcação para laminina também é um indicativo de polarização celular.

\section{Alterações no ciclo celular}

A cultura em 3 dimensões permitiu observar diferenças no número de células hipertetraplóides. A diminuição desta característica em ambiente 3D sugere que células MCF-7 com essa ploidia tenham um desenvolvimento melhor quando crescidas em monocamada. Lu et al. (136) mostraram que na linhagem tumoral de mama MDAMB 231, o crescente número de células hipertetraplóides confere a estas células um aumento no seu potencial metastático. Deste modo, ao analisarmos os nossos resultados, podemos inferir que a diminuição do número de células hipertetrapóides no ambiente 3D também seja um indicativo da gradual seleção de uma população 
celular com potencial para diferenciação. Outra diferença evidênciada foi o aumento da porcentagem de células na fase $\mathrm{G} 1$ do ciclo após serem submentidas a cultura 3D. A regulação desencadeada por pontos de checagem na fase G1 possui importante papel na progressão normal do ciclo. Tal característica é bastante alterada no câncer (137). Nossos resultados mostram que o ambiente tridimensional interfere nesta fase do ciclo, fato este evidenciado pela semelhante porcentagem de células em G1 no decorrer de toda cultura 3D.

\section{O aumento da expressão de RNAm para E-Caderina}

E-caderina é um dos mais estudados supressores de tumor em câncer de mama Esta molécula possui um importante papel na organização e polaridade do epitélio sendo a sua disfunção relacionada à progressão tumoral e metástases(138). Partindo destas informações, os resultados obtidos pela técnica quantitativa de RT-PCR por tempo real mostram que quanto maior o tempo de cultura 3D, maior é a expressão de RNAm para E-caderina. Juntamente com a análise morfológica, este fato mostra que a cultura 3D permitiu uma maior interação das células entre si ao longo do tempo de cultura. Desta maneira, estes resultados reforçam a viabilidade do modelo por este permitir a formação de um arranjo luminal com complexas interações célula-célula.

O aumento da expressão de RNAm para E-caderina manteve uma crescente na cultura 3D mesmo após os esferóides diferenciados (com 50 dias) terem sido colocados para crescer na forma de monocamada. Tal característica sugere que as células selecionadas pelo modelo de cultura 3D mantenham uma maior expressão de E-caderina, fato este que explicaria a formação de esferóides diferenciados em um período de tempo menor.

Após essas considerações, retomaremos a discussão sobre os modelos de cultura 3D que utilizam linhagem MCF-7. A importância do uso do Matrigel ${ }^{\circledR}$ nos diferentes sistemas de cultura em 3-dimensões é indiscutível. Entretanto, os dados do presente trabalho mostraram que a adição deste componente não foi necessária para iniciar os processos relacionados à cavitação dos esferóides. Como já apresentado anteriormente, a experimentação em cultura 3D de linhagem MCF-7 que obteve resultados mais próximos aos nossos se utilizou de um complexo sistema composto de colágeno + Matrigel ${ }^{\circledR}$ e fibroblastos (98). Neste contexto, a 
hipótese defendida nesta tese é de que existam na linhagem MCF-7 células que apresentam características mais próximas as encontradas em células normais. De alguma maneira ainda não tão bem compreendida, essas células se adaptariam melhor a forma de cultivo 3D proposto nesta tese. Juntamente com o crescimento desta população celular aumentaria também a presença de fatores relacionados à diferenciação tais como laminina e E-caderina. Não pode também ser descartada a possibilidade deste método reverter o fenótipo de forma contrária a transformação maligna, sendo a diferenciação e diminuição da proliferação independente da seleção.

\subsection{FATORES RELACIONADOS À FORMAÇÃO DO LÚMEN}

Por meio de diferentes abordagens foi mostrado que a apoptose está associada ao processo de cavitação para a formação do lúmen. No nosso modelo, a presença da apoptose refletiu em uma gradual diminuição do número de células da região medular, sendo que nos pontos finais analisados (30 e 50 dias de cultura 3D) o número de células em processo de apoptose aumentou. Debnath et al. em 2002 (139) e Debnath e Brugge em 2005 (140) já mostraram que o bloqueio de vias importantes da apoptose (proteínas anti apoptótica da família Bcl-2) não é capaz de impedir a formação do lúmen. Mills et al.(85) utilizando-se de um modelo semelhante sugerem que a cavitação de esferóides de células MCF-10A seria uma conseqüência da eliminação celular por autofagia e apoptose, duas vias distintas que se complementariam. Tais características também foram encontradas nos resultados apresentados neste presente trabalho. A maior expressão de LC3B associada ao autofagossomo ocorreu ao redor do trigésimo dia de cultura 3D, fase esta correspondente a fase com maior número de células em apoptose.

O efeito da ativação de ERK tanto em fatores pro quanto anti-apoptóticos (111), insere os resultados obtidos com a sua forma fosforilada no processo de formação luminal. Anderson et al. (122), descreveram que em esferóides de células MCF-10A a ativação de RAF 1 levaria a fosfolilação de ERK. Depois disto, ERK fosforilada ativaria uma proteína pró apoptótica da família Bcl-2, a BIM (141). Eles mostraram que, quanto maior era a presença de ERK fosforilada, menor era a formação de um espaço luminal. Isso ocorre, segundo estes autores, devido proteína BIM fosforilada ser direcionada para a degradação via proteossomo. No contexto do nosso modelo, obtivemos resultados semelhantes, haja visto que nos esferóides com o lúmem 
mais desenvolvido (50 dias de cultura 3D) encontramos a menor expressão de ERK fosforilada. Esferóides com esse tempo de cultura mostram outra característica importante, a maior expressão de PAR-4.

A proteína PAR -4 possui um importante papel na ativação da apoptose. A sua ligação tanto com a via intrínseca quanto extrínseca deste processo faz com que ela seja alvo de estudos relacionados com progressão tumoral $(142,143)$ e sobrevivência do câncer (144). Os resultados encontrados em esferóides com 50 dias de cultura mostraram aumento da expressão desta proteína quando comparado com os outros tempos de cultura analisados. Pelo fato da morfologia predominante em 50 dias de cultura 3D ser a de arranjo luminal, nossos resultados apontam para um possível papel desta proteína com a formação do lúmen. Nagai et al. (145) avaliaram a expressão de PAR-4 em diferentes tumores de mama, mostrando a possibilidade de uma relação entre a inativação desta proteína com um fenótipo mais agressivo. Com experimentos in vitro, esse grupo mostrou em esferóides de células MCF-10A, a positividade para PAR-4 nas células localizadas na região medular. Essa equivalência de resultados sugere que Par-4 também possua papel na formação de estruturas luminares, tanto em MCF-10A quanto em MCF-7.

Durante a formação do lúmen, algumas células apresentaram uma morfologia muito semelhante à descrita para o processo de entose. Este processo envolve a invasão de uma célula viva dentro da outra, seguido pela degradação das células internalizadas por enzimas lisossomais. Descrito em tumores e em linhagens de mama (entre elas MCF7 em suspensão) a ocorrência de entose está associada a populações celulares privadas de fixação a matriz extracelular (119). Quando crescidas em ambiemte 3D as células MCF7 apresentaram na formação do lúmen células em apoptose e em autofagia sendo envolvidas por entose, no entanto, também foram encontradas células em entose na região cortical do esferóide. Tal fato sugere que ligações célula-célula podem regular esse processo.

Um evento comumente descrito em esferóides é a formação do chamado núcleo necrótico. Esta classificação é decorrente da semelhança morfológica e conseqüente comparação entre a região central dos esferóides com regiões similares em metástases avasculares. $\mathrm{O}$ processo de necrose, o qual por muito tempo foi associado principalmente a hipóxia (146), não se apresentou como fator crucial na formação do lúmen, haja visto a presença marcante de apoptose e autofagia. Por meio de uma análise ultraestrutural, foi verificado células em estágio de necrose em todos os esferóides, inclusive no interior do lúmen. 
A sua proximidade com células da monocamada cortical diminuem as chances destas células estarem em hipóxia. Nossos resultados apontam para outras vias estarem regulando o processo de necrose. Golstein e Kroemer (147) discutem as vias de sinalização da necrose celular, havendo a possibilidade deste processo ser decorrente da falha tanto da apoptose quanto da autofagia

Desta maneira, mostramos que o modelo de cultivo celular em 3 dimensões estabelecido neste presente trabalho mostrou-se adequado para melhor compreender os processos relacionados a formação do espaço luminal. A similaridade com resultados descritos para modelos que utilizam linhagens normais reforça ainda mais que, nestas condições, características de células normais podem ser restabelecidas.

\subsection{A EXPRESSÃO DE AKT FOSFORILADA}

PTEN (phosphatase and tensin homolog) é uma fosfatase com uma atividade supressora de tumor que via interação com PI3K (phosphatidylinositol 3-kinases) regula a atividade de Akt (148) Quando ativada, AKT-fosforilada é um intenso promotor de sobrevivência uma vez que antagoniza e inativa vários componentes pró-apoptóticos como Bad (BCl-xL/BCl-2-associated death promoter) e caspase $9(148,149)$. Akt também tem influência no ciclo celular através da regulação de ciclina D1 como também inibindo p27 Kip1 $(150,151)$. Frente a essas possíveis interações, nossos resultados mostram uma intensa atividade desta proteína nas primeiras fases da cultura 3D. Tal fato talvez esteja relacionado a dois fatores principais: a resistência a anoikis e a proliferação celular. Debnath e colaboradores (151) ao estudarem essa proteína em esferóides de células MCF-10A também descreveram o aumento da sua expressão nas fases inicias da morfogênese, relacionando esse fato a uma maior resistência a anoikis. No nosso modelo, foi possível estabelecer uma relação mostrando que quanto maior a expressão de AKT fosforilada, menor é o processo de morte celular. Porém, pelo fato das células imunomarcadas localizarem-se na região cortical (na maioria das vezes em divisão celular), talvez os nossos resultados representem principalmente a interação desta proteína com o ciclo celular. 


\subsection{ADAMTS-1}

Quando comparamos os resultados obtidos entre a linhagem tumoral (MCF-7) com uma linhagem de célula normal (MCF-10A) (dados não mostrados), foi observado uma intensa imunomarcação para ADAMTS-1 na região nuclear das células MCF-7. Tal característica foi semelhantemente descrita em outra proteína pertencente à superfamília das metzincinas, a ADAM-10. McCulloch et al. (152) compararam imunohistoquímicas e western blots de cortes anatomopatológicos de tecido prostático normal com tecido neoplásico descrevendo pela primeira a presença tanto de uma regulação diferencial bem como diferentes funções desta proteína. Arima et al. (153) analisaram a expressão de ADAM-10 em linhagens de adenocarcinoma prostático, conseguindo relacionar a presença desta proteína no núcleo com receptores de andrógeno. Neste presente trabalho não foi possível, somente com a morfologia, inferir quais seriam as conseqüências da marcação nuclear em células tumorais. Entretanto, fica claro que exista uma localização diferenciada desta proteína ao se comparar 2DX3D, apontando para possíveis diferenças de funções.

A proteína ADAMTS -1 é uma metaloproteínase com função catalítica em substratos ricos em proteoglicanas, como versicam e agrecam (154). Todavia, muitas evidências vêm mostrando um importante papel desta proteína em questões relacionadas à invasão tumoral e metástase $(115,116)$. Estudos que relacionam níveis desta proteína e câncer tem se mostrado bastante contraditórios. Alguns autores mostraram que essa proteína é mais expressa em cânceres de mama e pâncreas, muitas vezes associado a um pior prognóstico $(155,156)$. Por outro lado, Porter et al. (157) mostraram que os cânceres de mama apresentaram uma menor expressão desta proteína. Devido a esse impasse Liu et al.(158) descreveram que quando secretada na sua forma completa (com 125 kDa), ADAMTS-1 tem função pró-apoptótica. Porém, quando fragmentada seu papel é alterado assumindo então uma função antiapoptótica. Vimos que em esferóides com 50 dias de cultura, somente o fragmento com 41kDa apresentou diferenças entre os grupos analisados. Apesar da diminuição deste fragmento em esferóides mais diferenciados, não é ainda possível afirmar se diminuição deste fragmento possui relação com esse processo de formação luminal. 


\subsection{TENSÃO DO AMBIENTE E MORFOGÊNESE}

A regulação da tensão mediada pelos componentes do citoesqueleto interage dinamicamente com fatores externos à célula. Assim, um ambiente que permita crescimento celular em diferentes planos per se já pode ser considerado um estímulo, o qual possibilita conseqüentes alterações morfogênicas. Ao se analisar a formação de esferóides de células MCF7 com lúmen, foi descrito a presença de crescentes brotamentos corticais regionalizados. Tal característica associada também a uma formação luminal nestes brotamentos mostra que o método de cultivo com maior tempo de cultura e ausência de complementação de laminina pode ser usado para o estudo da tubologênese. A formação destas estruturas assemelhou-se a micromorfogênese descrita por alguns autores $(68,159)$ os quais a relacionam com o estresse mecânico decorrente de alterações da matriz extracelular. O aumento tensional, tanto endógeno quanto exógeno, quando mediado por uma dureza prolongada da matriz pode ativar vias mecanoregulatórias (ERK e Rho) relacionadas e estabilização de contatos focais(160). Wozniak et al. (161) sugerem que células de mama em ambientes onde a matriz e mais flexível Rho quinase (ROCK) down regula a atividade de Rho levando a uma seqüência de eventos as quais resultam para uma diferenciação em túbulos.

\subsection{ESFERÓIDES DE MCF-7 COMO MODELO DE CULTURA 3D}

Os resultados apresentados neste trabalho mostraram a possibilidade da utilização de esferóides derivados de linhagens tumorais em estudos relacionados à formação luminal. A morfologia diferenciada, a qual integra dutos e ácinos, torna promissora a utilização deste modelo proposto. Quando associado a um processo de seleção, vimos que essas mudanças na morfologia podem ser obtidas em um menor espaço de tempo. Tal fato viabilizaria a utilização destes esferóides nos moldes dos modelos de cultura 3D atuais (esferóides de MCF-10A, por exemplo). Assim, aspectos estudados somente em linhagens normais podem agora ser analisados em um modelo que apresente a mesma característica, só que obtido por meio de uma linhagem tumoral. 


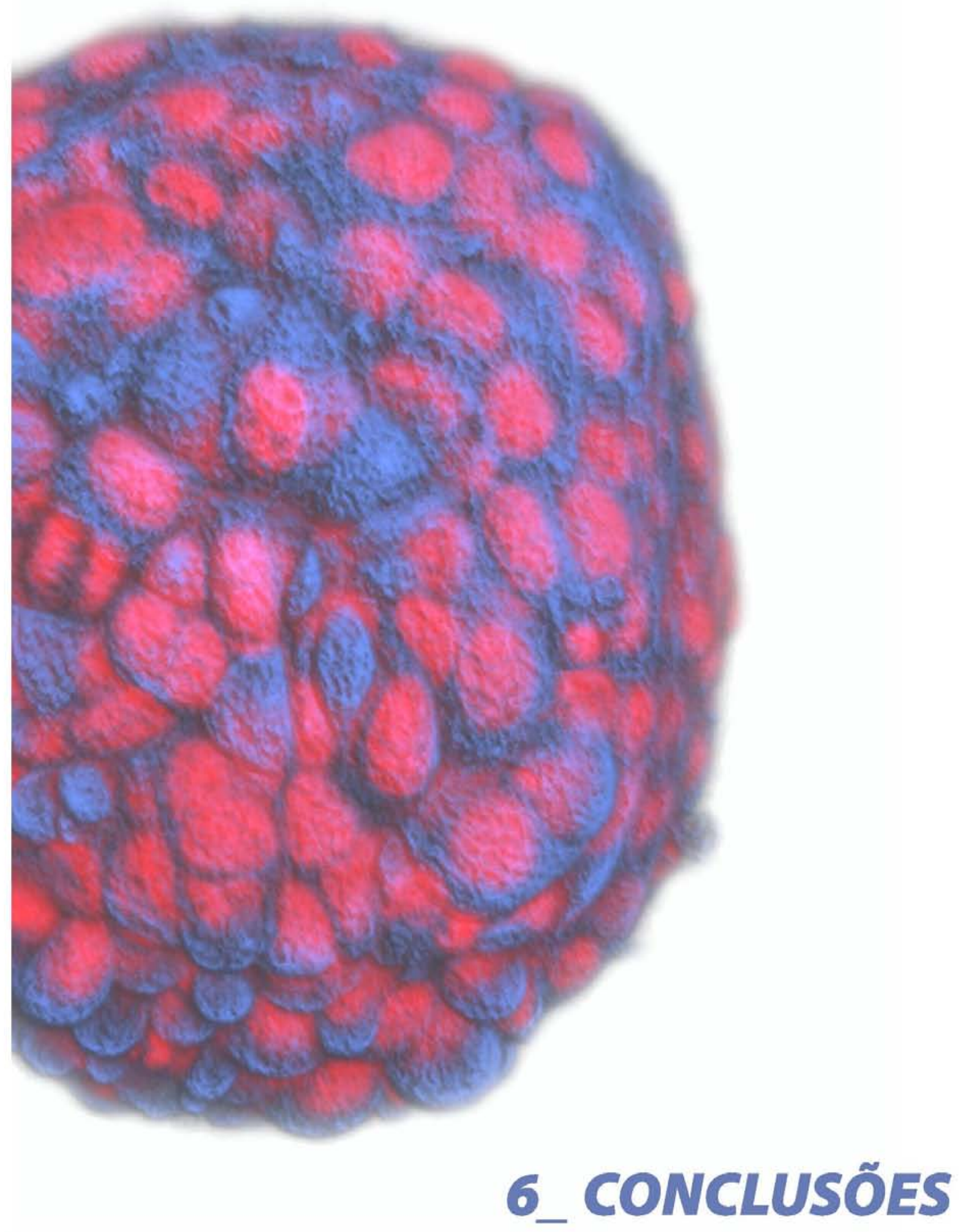


Os resultados apresentados neste trabalho permitem concluir que:

- A formação de estruturas acinares e tubulares (ambas com espaço luminal) em esferóides de células MCF-7 não é dependente de uma suplementação com componentes de membrana basal.

- As modificações tanto na morfologia quanto na expressão das proteínas analisadas não estão limitadas as mudanças do ambiente 2D para 3D. Estas podem também ocorrer ao longo do tempo de cultura em 3- Dimensões.

- O método de formação de esferóides proposto por esse trabalho permite o uso de linhagens MCF-7 como modelo para estudos relacionados à formação do lúmen.

- Células que já passaram pelo processo de diferenciação durante a cultura 3D, mesmo após seu retorno a monocamada, formam esferóides com arranjo luminal em um menor período de tempo. 


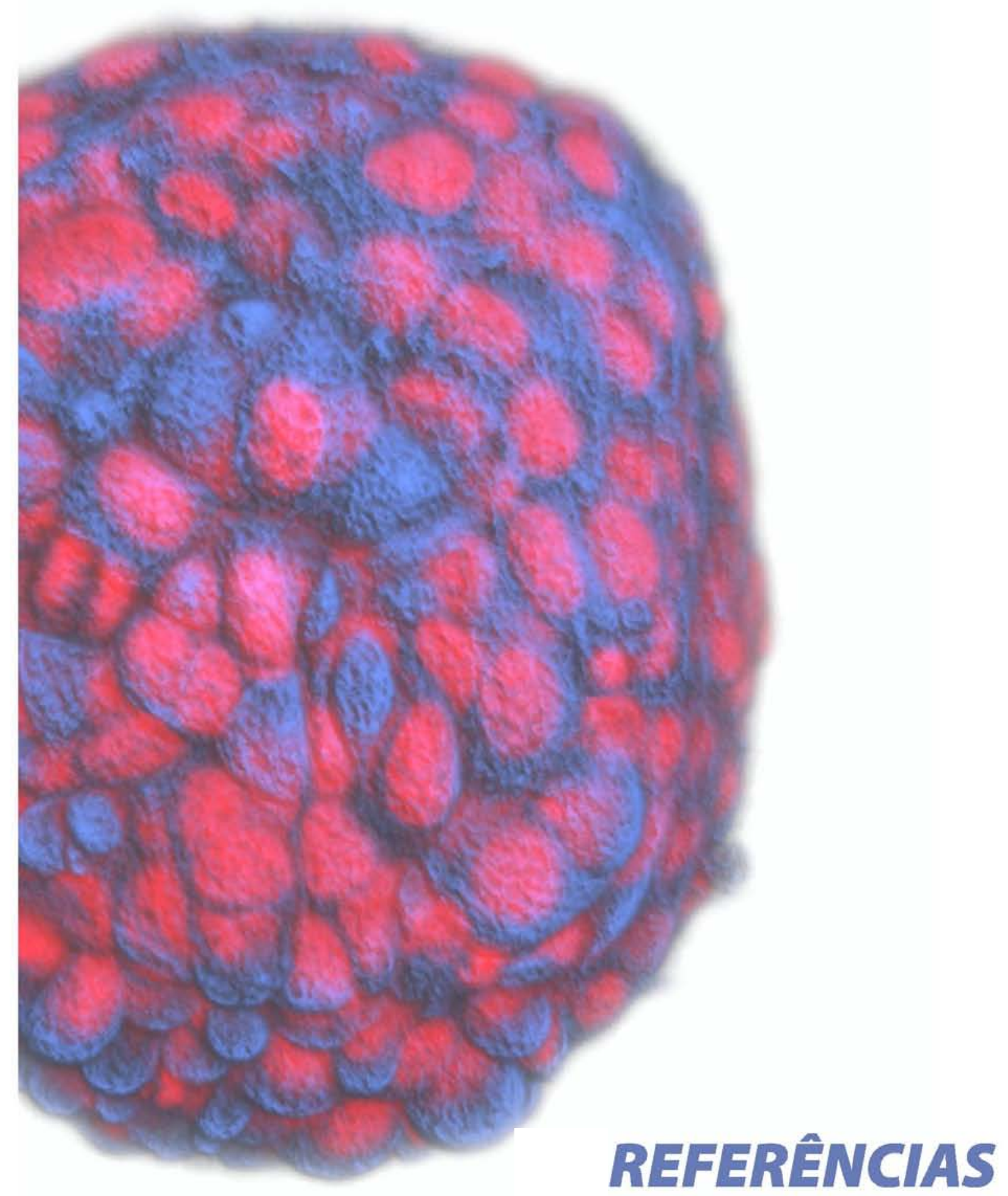




\section{REFERÊNCIAS*}

1. Keshishian H. Ross Harrison's "The outgrowth of the nerve fiber as a mode of protoplasmic movement". Journal of Experimental Zoology Part A: Comparative Experimental Biology. 2004;301A(3):201-3.

2. Harrison RG. Observations on the living developing nerve fiber. Anatomical Record 1907;1:116-8.

3. Harrison RG. The outgrowth of the nerve fiber as a mode of protoplasmic movement. Journal of Experimental Zoology. 1910;9(4):787-846.

4. Witkowski JA. Alexis Carrel and the mysticism of tissue culture. Medical History. 1979;23:279-96.

5. Friedman M, Friedland GW. Medicine's 10 Greatest Discoveries. New Haven: Yale University Press; 2000.

6. Carrel A. On the permanent life of tissues outside of the organism. Journal of Experimental Medicine. 1912;15:516-28.

7. Byrnes WM. Ernest Everett Just, Johannes Holtfreter, and the origin of certain concepts in embryo morphogenesis. Molecular Reproduction and Development. 2009;76(10):912-21.

8. Holtfreter J. A study of the mechanics of gastrulation. Journal of Experimental Zoology. 1944;95(2):171-212.

9. Holtfreter J. Neural induction in explants which have passed through a sublethal cytolysis. Journal of Experimental Zoology. 1947;106(2):197-222.

10. Johnson LG. Patterns \& Experiments in Developmental Biology. 3rd ed. Boston: McGraw-Hill Companies; 2001.

11. Moscona A. The development in vitro of chimeric aggregates of dissociated embryonic chick and mouse cells. Proceedings of the National Academy of Sciences of the United States of America. 1957;43(1):184-94.

\footnotetext{
*De acordo com: International Committee of Medical Journal Editors. Uniform requirements for manuscripts submitted to Biomedical Journal: sample references. Available from: http://www.icmje.org [2007 May 22].
} 
12. Moscona A. Cell suspensions from organ rudiments of chick embryos. Experimental Cell Research. 1952;3(3):535-9.

13. Moscona A. Formation of lentoids by dissociated retinal cells of the chick embryo. Science. 1957;125:598-9.

14. Moscona AA. Rotation-mediated histogenetic aggregation of dissociated cells : A quantifiable approach to cell interactions in vitro. Experimental Cell Research. 1961;22:455-75.

15. Winzler RJ. Carbohydrates in Cell Surfaces. In: Bourne GH, Daniele JF, Jeon KW, editors. International Review of Cytology. London: Academic Press; 1970. p. 77-125.

16. Schaeffer WI. In memorium -- a tribute to Dr. Joseph Leighton. Methods in Cell Science. $1999 ; 21(1): 1-4$.

17. Leighton J. A sponge matrix method for tissue culture. Formation of organized aggregates of cell in vitro. Journal of the National Cancer Institute. 1951;12:545-61.

18. Leighton J. The growth patterns of some trasnplantable animal tumors in sponge matrix tissue culture. Journal of the National Cancer Institute. 1954;15:275-93.

19. World Heath Organization. Cancer Statistics. 2010 [cited 2010 nov 16]; Available from: http://globocan.iarc.fr/factsheets/cancers/all.asp.

20. Instituto Nacional do Câncer. Estimativa 2010. Rio de Janeiro; 2010 [cited 2010 nov 16]; Availablefrom:

http://www.inca.gov.br/estimativa/2010/index.asp?link=conteudo view.asp\&ID=5.

21. Weinberg RA. A biologia do câncer. Porto Alegre: Artmed; 2008.

22. Hahn WC, Weinberg RA. Rules for Making Human Tumor Cells. New England Journal of Medicine. 2002;347(20):1593-603.

23. Hanahan D, Weinberg RA. The hallmarks of cancer. Cell. 2000;100:57-70.

24. Lelièvre S. Tissue Polarity-Dependent Control of Mammary Epithelial Homeostasis and Cancer Development: an Epigenetic Perspective. Journal of Mammary Gland Biology and Neoplasia. 2010;15(1):49-63. 
25. Sawan C, Vaissière T, Murr R, Herceg Z. Epigenetic drivers and genetic passengers on the road to cancer. Mutation Research/Fundamental and Molecular Mechanisms of Mutagenesis. 2008;642(1-2):1-13.

26. Ellsworth RE, Decewicz DJ, Shriver CD, Ellsworth DL. Breast Cancer in the Personal Genomics Era. Current Genomics. 2010; 11:146-61.

27. Tiezz DG. Epidemiologia do câncer de mama. Revista Brasileira de Ginecologia e Obstetrícia. 2009;31(5):213-5.

28. Kreeger PK, Lauffenburger DA. Cancer systems biology: a network modeling perspective. Carcinogenesis 2010;31(1):2-8.

29. McAllister RM, Reed G, Huebner RJ. Colonial growth in agar of cells derived from adenovirus-induced hamster tumors. Journal of the National Cancer Institute. 1967;39:43-53.

30. Halpern B, Pejsachowicz B, Febvre HL, Barski G. Differences in Patterns of Aggregation of Malignant and Non-Malignant Mammalian Cells. Nature. 1966;209 (5019):157-9.

31. Sutherland RM, McCredie JA, Inch WR. Growth of multicell spheroids in tissue culture as a model of nodular carcinomas. J Natl Cancer Inst. 1971;46:113-20.

32. Inch W, McCredie J, Sutherland R. Growth of nodular carcinomas in rodents compared with multi-cell spheroids in tissue culture. Growth. 1970;34:271-82.

33. Sutherland R, Durand R. Radiosensitization by nifuroxime of the hypoxic cells in an in vitro tumour model. International Journal of Radiation Biology. 1972;22:613-8.

34. Sutherland RM, Inch WR, McCredie JA, Kruuv J. A multicomponent radiation survival curve using an in vitro tumour model. International Journal of Radiation Biology. 1970;18:4915.

35. Kim JB. Three-dimensional tissue culture models in cancer biology. Seminars in Cancer Biology. 2005;15(5):365-77.

36. Durand RE, Sutherland RM. Effects of intercellular contact on repair of radiation damage. Experimental Cell Research. 1972;71(1):75-80.

37. Siemann DW, Sutherland RM. The Interaction between Adriamycin and Radiation in a Solid Murine Tumor. Radiation Research. 1980;83(2):345-59. 
38. Durand RE, Brown SM. Effects of lucanthone on chinese hamster V-79 cells I. Interaction with radiation in monolayers and spheroids. International Journal of Radiation Oncology*Biology*Physics. 1980;6(11):1525-30.

39. Stephanie $H$, Inga L, Iris E, Nils C. 3D cell cultures of human head and neck squamous cell carcinoma cells are radiosensitized by the focal adhesion kinase inhibitor TAE226. Radiotherapy and oncology : journal of the European Society for Therapeutic Radiology and Oncology. 2009;92(3):371-8.

40. Stephanie H, Iris E, Katja S, Michael H, Gustavo BB, Nils C. Caveolin-1 mediated radioresistance of 3D grown pancreatic cancer cells. Radiotherapy and oncology : journal of the European Society for Therapeutic Radiology and Oncology. 2009;92(3):362-70.

41. Storch K, Eke I, Borgmann K, Krause M, Richter C, Becker K, et al. Three-Dimensional Cell Growth Confers Radioresistance by Chromatin Density Modification. Cancer Research. 2010 May 15, 2010;70(10):3925-34.

42. Carlsoon J, Yuhas JM. Liquid-overlay culture of cellular spheroids Recent Results in Cancer Research. 1984;95:1-23.

43. Sutherland RM, Eddy HA, Bareham B, Reich K, Vanantwerp D. Resistance to adriamycin in multicellular spheroids. International Journal of Radiation Oncology*Biology*Physics. 1979;5(8):1225-30.

44. Kerr DJ, Wheldon TE, Hydns S, Kaye SB. Cytotoxic drug penetration studies in multicellular tumour spheroids. Xenobiotica. 1988;18(6):641-8.

45. Bichay TJ, Inch WR. Resistance of V79 multicell spheroids to mitoxantrone: drug uptake and cytotoxicity. Cancer Drug Delivery. 1987;4 (4):201-11.

46. Jaaskelainen J, Kalliomaki P, Paetau A, Timonen T. Effect of LAK cells against threedimensional tumor tissue. In vitro study using multi-cellular human glioma spheroids as targets. The Journal of Immunology. 1989;142(3):1036-45.

47. Lin R-Z, Chang H-Y. Recent advances in three-dimensional multicellular spheroid culture for biomedical research. Biotechnology Journal. 2008;3(9-10):1172-84.

48. Friedrich J, Ebner R, Kunz-Schughart LA. Experimental anti-tumor therapy in 3-D: Spheroids - old hat or new challenge? International Journal of Radiation Biology. 2007;83(1112):849-71. 
49. Mueller-Klieser W. Multicellular spheroids. Journal of Cancer Research and Clinical Oncology. 1987;113(2):101-22.

50. Hirschhaeuser F, Menne H, Dittfeld C, West J, Mueller-Klieser W, Kunz-Schughart LA. Multicellular tumor spheroids: An underestimated tool is catching up again. Journal of Biotechnology. 2010;148(1):3-15.

51. Miller BE, Miller FR, Heppner GH. Factors Affecting Growth and Drug Sensitivity of Mouse Mammary Tumor Lines in Collagen Gel Cultures. Cancer Research. 1985;45(9):4200-5.

52. Steeg PS, Alley MC, Grever MR. An Added Dimension: Will Three-Dimensional Cultures Improve Our Understanding of Drug Resistance? Journal of the National Cancer Institute. 1994;86(13):953-5.

53. Kunz-Schughart LA, Freyer JP, Hofstaedter F, Ebner R. The use of 3D cultures for highthroughput screening: the multicellular spheroid model. J Biomol Screen. 2004;9:273-84.

54. Cukierman E, Pankov R, Stevens DR, Yamada KM. Taking cell-matrix adhesions to the third dimension. Science. [10.1126/science.1064829]. 2001;294:1708-12.

55. Elliott NT, Yuan F. A review of three-dimensional in vitro tissue models for drug discovery and transport studies. Journal of Pharmaceutical Sciences. 2010. In Press.

56. Kim SHJ, Park S, Mostov K, Debnath J, Hunt A. Computational investigation of epithelial cell dynamic phenotype in vitro. Theoretical Biology and Medical Modelling. 2009;6(8):10-6.

57. Chignola R, Schenetti A, Andrighetto G, Chiesa E, Foroni R, Sartoris S, et al. Forecasting the growth of multicell tumour spheroids: implications for the dynamic growth of solid tumours. Cell Proliferation. 2000;33(4):219-29.

58. Mazzoleni G, Di Lorenzo D, Steimberg N. Modelling tissues in 3D: the next future of pharmaco-toxicology and food research? Genes \& Nutrition. 2009;4(1):13-22.

59. Kunz-Schughart LA, Kreutz M, Knuechel R. Multicellular spheroids: a three-dimensional in vitro culture system to study tumour biology. International Journal of Experimental Pathology. 1998;79(1):1-23.

60. Feder-Mengus C, Ghosh S, Reschner A, Martin I, Spagnoli G. New dimensions in tumor immunology: what does 3D culture reveal? Trends Mol Med. 2008;14(8):333-40. 
61. Morales J, Alpaugh M. Gain in cellular organization of inflammatory breast cancer: A 3D in vitro model that mimics the in vivo metastasis. BMC Cancer. 2009;9(1):462.

62. Pietras K, Östman A. Hallmarks of cancer: Interactions with the tumor stroma. Experimental Cell Research. 2010;316(8):1324-31.

63. DiMasi JA, Hansen RW, Grabowski HG. The price of innovation: new estimates of drug development costs. Journal of Health Economics. 2003;22(2):151-85.

64. DiMasi JA, Grabowski HG. Economics of New Oncology Drug Development. Journal of Clinical Oncology. 2007;25(2):209-16.

65. Rangarajan A, Hong SJ, Gifford A, Weinberg RA. Species- and cell type-specific requirements for cellular transformation. Cancer Cell. 2004;6(2):171-83.

66. Abbott A. Cell culture: Biology's new dimension. Nature. 2003;424(6951):870-2

67. Mueller-Klieser W. Tumor biology and experimental therapeutics. Critical reviews in oncology/hematology. 2000;36(2):123-39.

68. Ingber DE. Tensegrity-based mechanosensing from macro to micro. Progress in Biophysics and Molecular Biology. 2008;97(2-3):163-79.

69. Schmeichel K, Bissell M. Modeling tissue-specific signaling and organ function in three dimensions. J Cell Sci. 2003;116(Pt 12):2377-88.

70. Ingram $\mathrm{M}$, Techy $\mathrm{G}$, Ward $\mathrm{B}$, Imam S, Atkinson $\mathrm{R}, \mathrm{Ho} \mathrm{H}$, et al. Tissue engineered tumor models. Biotechnic \& Histochemistry. 2010;85(4):213-29.

71. Dhimolea E, Maffini MV, Soto AM, Sonnenschein C. The role of collagen reorganization on mammary epithelial morphogenesis in a 3D culture model. Biomaterials. 2010;31(13):362230.

72. Kenny PA, Lee GY, Myers CA, Neve RM, Semeiks JR, Spellman P, T. , et al. The morphologies of breast cancer cell lines in three-dimensional assays correlate with their profiles of gene expression. Molecular oncology. 2007;1(1):84-96.

73. Dabrowska-Piaskowska K. Observations on the histoformative capacities of tumor cells dissociated by digestion with trypsin. Experimental Cell Research. 1959;16(2):315-23. 
74. Yang J, Richards J, Bowman P, Guzman R, Enami J, Mccormick K, et al. Sustained growth and three-dimensional organization of primary mammary tumor epithelial cells embedded in collagen gels. Proceedings of the National Academy of Sciences of the United States of America. 1979; 76(7):3401-5.

75. Hall HG, Farson DA, Bissell MJ. Lumen formation by epithelial cell lines in response to collagen overlay: a morphogenetic model in culture. Proceedings of the National Academy of Sciences of the United States of America. 1982;79(15):4672-6.

76. Benton G, George J, Kleinman HK, Arnaoutova IP. Advancing science and technology via 3D culture on basement membrane matrix. Journal of Cellular Physiology. 2009;221(1):18-25.

77. Nelson WJ. Remodeling Epithelial Cell Organization: Transitions Between Front-Rear and Apical-Basal Polarity. Cold Spring Harbor Perspectives in Biology. 2009;1(1) 33-40.

78. Kleinman HK, Martin GR. Matrigel: Basement membrane matrix with biological activity. Seminars in Cancer Biology. 2005;15(5):378-86.

79. Kleinman HK. Basement membrane complexes with biological activity. Biochemistry. $1986 ; 25: 312-8$.

80. Petersen OW, Ronnov-Jessen L, Howlett AR, Bissell MJ. Interaction with basement membrane serves to rapidly distinguish growth and differentiation pattern of normal and malignant human breast epithelial cells. Proc Natl Acad Sci USA. 1992;89:9064-8.

81. Briand P, Petersen OW, Van Deurs B. A new diploid nontumorigenic human breast epithelial cell line isolated and propagated in chemically defined medium. In Vitro Cell Dev Biol. 1987;23:181-8.

82. Weaver V, Petersen O, Wang F, Larabell C, Briand P, Damsky C, et al. Reversion of the malignant phenotype of human breast cells in three-dimensional culture and in vivo by integrin blocking antibodies. J Cell Biol. 1997;137:231-45.

83. Bissell MJ, Radisky D. Putting tumours in context. Nature Rev Cancer. 2001;1:46-54.

84. Debnath J, Muthuswamy SK, Brugge JS. Morphogenesis and oncogenesis of MCF-10A mammary epithelial acini grown in three-dimensional basement membrane cultures. Methods. 2003;30:256-68. 
85. Mills KR, Reginato M, Debnath J, Queenan B, Brugge JS. Tumor necrosis factor-related apoptosis-inducing ligand (TRAIL) is required for induction of autophagy during lumen formation in vitro. Proc Natl Acad Sci USA. 2004;101:3438-43.

86. Soule HD, Maloney TM, Wolman SR, Peterson WD, Brenz R, McGrath CM, et al. Isolation and Characterization of a Spontaneously Immortalized Human Breast Epithelial Cell Line, MCF10. Cancer Research. 1990;50(18):6075-86.

87. Debnath J. The role of apoptosis in creating and maintaining luminal space within normal and oncogene-expressing mammary acini. Cell. 2002;111:29-40.

88. Maiuri MC, Tasdemir E, Criollo A, Morselli E, Vicencio JM, Carnuccio R, et al. Control of autophagy by oncogenes and tumor suppressor genes. Cell Death Differ. 2008;16(1):87-93.

89. Levine B. Cell biology: autophagy and cancer. Nature. 2007;446:745-7.

90. Levine B, Kroemer G. Autophagy in the Pathogenesis of Disease. Cell. 2008;132(1):27-42.

91. Underwood JM, Imbalzano KM, Weaver VM, Fischer AH, Imbalzano AN, Nickerson JA. The ultrastructure of MCF-10A acini. Journal of Cellular Physiology. 2006;208(1):141-8.

92. Mills KR, Reginato M, Debnath J, Queenan B, Brugge JS. Tumor necrosis factor-related apoptosis-inducing ligand (TRAIL) is required for induction of autophagy during lumen formation in vitro. Proceedings of the National Academy of Sciences of the United States of America. 2004;101(10):3438-43.

93. Fung C, Lock R, Gao S, Salas E, Debnath J. Induction of autophagy during extracellular matrix detachment promotes cell survival. Mol Biol Cell. 2008;19:797-806.

94. Soule HD, Vazguez J, Long A, Albert S, Brennan M. A human cell line from a pleural effusion derived from a breast carcinoma. Journal of the National Cancer Institute. 1973;51(3):1409-16.

95. Debeb BG, Xu W, Mok H, Li L, Robertson F, Ueno NT, et al. Differential Radiosensitizing Effect of Valproic Acid in Differentiation Versus Self-Renewal Promoting Culture Conditions. International Journal of Radiation Oncology*Biology*Physics. 2010;76(3):889-95.

96. Ivascu A, Kubbies M. Diversity of cell-mediated adhesions in breast cancer spheroids. International Journal of Oncology. 2007; 31:1403-13 
97. Kirshner J, Chen CJ, Liu P, Huang J, Shively JE. CEACAM1-4S, a cell-cell adhesion molecule, mediates apoptosis and reverts mammary carcinoma cells to a normal morphogenic phenotype in a 3D culture. Proc Natl Acad Sci USA. 2003;100:521-6.

98. Krause S, Maffini M, Soto A, Sonnenschein C. The microenvironment determines the breast cancer cells' phenotype: organization of MCF7 cells in 3D cultures. BMC Cancer. 2010;10(263)

99. Guo H-B, Johnson H, Randolph M, Nagy T, Blalock R, Pierce M. Specific posttranslational modification regulates early events in mammary carcinoma formation. Proceedings of the National Academy of Sciences. 2010;107(49):21116-21.

100. Debnath J, Muthuswamy S, Brugge J. Morphogenesis and oncogenesis of MCF-10A mammary epithelial acini grown in three-dimensional basement membrane cultures. Methods. 2003;30:256-68.

101. Allan LA, Clarke PR. Apoptosis and autophagy: Regulation of caspase-9 by phosphorylation. FEBS Journal. 2009;276(21):6063-73.

102. Overexpression of Par-4 sensitizes TRAIL-induced apoptosis via inactivation of NFkappaB and Akt signaling pathways in renal cancer cells. Molecular cell. 2005;20(1):33-4.

103. Zhao Y, Rangnekar VM. Apoptosis and tumor resistance conferred by Par-4. Cancer Biology \& Therapy. 2008;7 (12):1867-74.

104. Joshi J, Fernandez-Marcos PJ, Galvez A, Amanchy R, Linares JF, Duran A, et al. Par-4 inhibits Akt and suppresses Ras-induced lung tumorigenesis. EMBO J. 2008;27(16):2181-93.

105. Gurumurthy S, Goswami A, Vasudevan KM, Rangnekar VM. Phosphorylation of Par-4 by Protein Kinase A Is Critical for Apoptosis. Mol Cell Biol. 2005;25(3):1146-61.

106. Chen Z-H, Lam HC, Jin Y, Kim H-P, Cao J, Lee S-J, et al. Autophagy protein microtubuleassociated protein 1 light chain-3B (LC3B) activates extrinsic apoptosis during cigarette smokeinduced emphysema. Proceedings of the National Academy of Sciences. 2010;107(44):18880-5.

107. Kabeya Y, Mizushima N, Ueno T, Yamamoto A, Kirisako T, Noda T, et al. LC3, a mammalian homologue of yeast Apg8p, is localized in autophagosome membranes after processing. EMBO J. 2000;19(21):5720-8. 
108. Mariño G, Fernández AF, Cabrera S, Lundberg YW, Cabanillas R, Rodríguez F, et al. Autophagy is essential for mouse sense of balance. The Journal of Clinical Investigation. 2010;120(7):2331-44.

109. Manning BD, Cantley LC. AKT/PKB signaling: navigating downstream. Cell. 2007;129:1261-74.

110. Srinivasan S, Koduru S, Kumar R, Venguswamy G, Kyprianou N, Damodaran C. Diosgenin targets Akt-mediated prosurvival signaling in human breast cancer cells. International Journal of Cancer. 2009;125(4):961-7.

111. Kolch W. Meaningful relationships: the regulation of the Ras/Raf/MEK/ERK pathway by protein interactions. Biochem J. 2000;351:289-305.

112. Calvo F, Agudo-Ibáñez L, Crespo P. The Ras-ERK pathway: Understanding site-specific signaling provides hope of new anti-tumor therapies. Bioessays. 2010;32(5):412-21.

113. Chao Y, Shepard C, Wells A. Breast carcinoma cells re-express E-cadherin during mesenchymal to epithelial reverting transition. Molecular Cancer. 2010;9(1):179.

114. Onder T, Gupta P, Mani S, Yang J, Lander E, Weinberg R. Loss of E-cadherin promotes metastasis via multiple downstream transcriptional pathways. Cancer Res. 2008;68:3645-54.

115. Tortorella MD, Malfait F, Barve RA, Shieh HS, Malfait AM. A review of the ADAMTS family, pharmaceutical targets of the future. Curr Pharm Des. 2009;15(20):2359-74.

116. Rocks N, Paulissen G, Quesada-Calvo F, Munaut C, Gonzalez M-LA, Gueders M, et al. ADAMTS-1 Metalloproteinase Promotes Tumor Development through the Induction of a Stromal Reaction In vivo. Cancer Research. 2008;68(22):9541-50.

117. Karnovsky MJ. A formaldehyde-glutaraldehyde fixative of high osmolality for use in electron microscopy. Journal of Cell Biology 1965;27:137-8A.

118. Le Bot N. Entosis: cell death by invasion. Nat Cell Biol. 2007;9(12):1346-.

119. Overholtzer M, Mailleux AA, Mouneimne G, Normand G, Schnitt SJ, King RW, et al. A Nonapoptotic Cell Death Process, Entosis, that Occurs by Cell-in-Cell Invasion. Cell. 2007;131(5):966-79. 
120. Lubarsky B, Krasnow MA. Tube Morphogenesis: Making and Shaping Biological Tubes. Cell. 2003;112(1):19-28.

121. Martín-Belmonte F, Yu W, Rodríguez-Fraticelli AE, Ewald A, Werb Z, Alonso MA, et al. Cell-Polarity Dynamics Controls the Mechanism of Lumen Formation in Epithelial Morphogenesis. Current Biology. 2008;18(7):507-13.

122. Anderson LR, Sutherland RL, Butt AJ. BAG-1 overexpression attenuates luminal apoptosis in MCF-10A mammary epithelial cells through enhanced RAF-1 activation. Oncogene. 2009;29(4):527-38.

123. Freitas VM, Rangel M, Bisson LF, Jaeger RG, Machado-Santelli GM. The geodiamolide H, derived from brazilian sponge Geodia corticostylifera, regulates actin cytoskeleton, migration and invasion of breast cancer cells cultured in three-dimensional environment. Journal of Cellular Physiology. 2008;216(3):583-94.

124. Debnath J, Brugge JS. Modelling glandular epithelial cancers in three-dimensional cultures. Nat Rev Cancer. 2005;5(9):675-88.

125. Mailleux AA, Overholtzer M, Brugge JS. Lumen formation during mammary epithelial morphogenesis: insights from in vitro and in vivo models. Cell Cycle. 2008;7(1):57-62.

126. Lacroix M, Leclercq G. Relevance of Breast Cancer Cell Lines as Models for Breast Tumours: An Update. Breast Cancer Research and Treatment. 2004;83(3):249-89.

127. Fischbach $\mathrm{C}$, Chen R, Matsumoto T, Schmelzle T, Brugge JS, Polverini PJ, et al. Engineering tumors with 3D scaffolds. Nat Methods. 2007;4:855-90.

128. Dhiman HK, Ray AR, Panda AK. Three-dimensional chitosan scaffold-based MCF-7 cell culture for the determination of the cytotoxicity of tamoxifen. Biomaterials. 2005;26(9):979-86.

129. Chen C-J, Nguyen T, Shively JE. Role of calpain-9 and PKC-[delta] in the apoptotic mechanism of lumen formation in CEACAM1 transfected breast epithelial cells. Experimental Cell Research. 2010;316(4):638-48.

130. Burdall S, Hanby A, Lansdown M, Speirs V. Breast cancer cell lines: friend or foe? Breast Cancer Res. 2003;5(2):89-95. 
131. Fillmore $\mathrm{C}$, Kuperwasser $\mathrm{C}$. Human breast cancer cell lines contain stem-like cells that self-renew, give rise to phenotypically diverse progeny and survive chemotherapy. Breast Cancer Research. 2008;10(2):R25.

132. Grimshaw M, Cooper L, Papazisis K, Coleman J, Bohnenkamp H, Chiapero-Stanke L, et al. Mammosphere culture of metastatic breast cancer cells enriches for tumorigenic breast cancer cells. Breast Cancer Research. 2008;10(3):R52.

133. Calcagno AM, Salcido CD, Gillet J-P, Wu C-P, Fostel JM, Mumau MD, et al. Prolonged Drug Selection of Breast Cancer Cells and Enrichment of Cancer Stem Cell Characteristics. Journal of the National Cancer Institute. 2010 November 3, 2010;102(21):1637-52.

134. Shivas JM, Morrison HA, Bilder D, Skop AR. Polarity and endocytosis: reciprocal regulation. Trends in Cell Biology. 2010;20(8):445-52.

135. Hogan BLM, Kolodziej PA. Molecular Mechanisms Of Tubulogenesis. Nat Rev Genet.. 2002;3(7):513-23.

136. Lu X, Lu X, Kang Y. Organ-specific enhancement of metastasis by spontaneous ploidy duplication and cell size enlargement. Cell Res. 2010;20(9):1012-22.

137. 137. Yan J, Luo D, Luo Y, Gao X, Zhang G. Induction of $\mathrm{G} 1$ arrest and differentiation in MDA-MB-231 breast cancer cell by boehmeriasin $A$, a novel compound from plant. International Journal of Gynecological Cancer. 2006;16(1):165-70.

138. 138. Baranwal S, Alahari SK. Molecular mechanisms controlling E-cadherin expression in breast cancer. Biochemical and biophysical research communications. 2009;384(1):6-11

139. Debnath J, Mills KR, Collins NL, Reginato MJ, Muthuswamy SK, Brugge J. The role of apoptosis in creating and maintaining luminal space within normal and oncogene-expressing mammary acini. Cell. 2002;111:29-40.

140. Debnath J, Brugge J. Modelling glandular epithelial cancers in three-dimensional cultures. Nat Rev Cancer. 2005;5(9):675 - 88.

141. O'Connor L, Strasser A, O'Reilly LA, Hausmann G, Adams JM, Cory S, et al. Bim: a novel member of the Bcl-2 family that promotes apoptosis. EMBO J. 1998;17(2):384-95. 
142. Barradas M, Monjas A, Diaz-Meco MT, Serrano M, Moscat J. The downregulation of the pro-apoptotic protein Par-4 is critical for Ras-induced survival and tumor progression. EMBO J. 1999;18:6362-9.

143. Moreno-Bueno G, Fernandez-Marcos PJ, Collado M, Tendero MJ, Rodriguez-Pinilla SM, Garcia-Cao I, et al. Inactivation of the candidate tumor suppressor par-4 in endometrial cancer. Cancer Res. 2007;67:1927-34.

144. Goswami A, Burikhanov R, de Thonel A, Fujita N, Goswami M, Zhao Y, et al. Binding and phosphorylation of par-4 by akt is essential for cancer cell survival. Mol Cell. 2005;20:33-44.

145. Nagai MP, Gerhard R, Salaorni S, Fregnanit JHGT, Nonogaki S, Netto MM, et al. Downregulation of the candidate tumor suppressor gene PAR-4 is associated with poor prognosis in breast cancer. International Journal of Oncology 2010;37:41-9.

146. Acker H, Carlsson J, Durand RE, Sutherland R. Spheroids in cancer research. Berlin Heidelberg: Springer-Verlag; 1984.

147. Golstein P, Kroemer G. Cell death by necrosis: towards a molecular definition. Trends in Biochemical Sciences. 2007;32(1):37-43.

148. Carnero A, Blanco-Aparicio C, Renner O, Link W, Leal JF. The PTEN/PI3K/AKT signalling pathway in cancer, therapeutic implications. Curr Cancer Drug Targets. 2008;8(3):187-98.

149. Bellacosa A, Chan TO, Ahmed NN, Datta K, Malstrom S, Stokoe D, et al. Akt activation by growth factors is a multiple-step process: the role of the PH domain. Oncogene. 1998;17:31325.

150. Testa JR, Bellacosa A. AKT plays a central role in tumorigenesis. Proceedings of the National Academy of Sciences of the United States of America. 2001;98(20):10983-5.

151. Debnath J, Walker SJ, Brugge JS. AKT activation disrupts mammary acinar architecture and enhances proliferation in an mTOR-dependent manner. J Cell Biol. 2003;163:315-26.

152. McCulloch DR, Akl P, Samaratunga H, Herington AC, Odorico DM. Expression of the Disintegrin Metalloprotease, ADAM-10, in Prostate Cancer and Its Regulation by Dihydrotestosterone, Insulin-Like Growth Factor I, and Epidermal Growth Factor in the Prostate Cancer Cell Model LNCaP. Clinical Cancer Research. 2004 ;10(1):314-23. 
153. Arima T, Enokida H, Kubo H, Kagara I, Matsuda R, Toki K, et al. Nuclear translocation of ADAM-10 contributes to the pathogenesis and progression of human prostate cancer. Cancer Science. 2007;98(11):1720-6.

154. Brown HM, Dunning KR, Robker RL, Pritchard M, Russell DL. Requirement for ADAMTS-1 in extracellular matrix remodeling during ovarian folliculogenesis and lymphangiogenesis. Developmental Biology. 2006;300(2):699-709.

155. Kang Y, Siegel PM, Shu W, Drobnjak M, Kakonen SM, Cordón-Cardo C, et al. A multigenic program mediating breast cancer metastasis to bone. Cancer Cell. 2003;3(6):537-49.

156. Masui T, Hosotani R, Tsuji S, Miyamoto Y, Yasuda S, Ida J, et al. Expression of METH-1 and METH-2 in Pancreatic Cancer. Clinical Cancer Research. 2001;7(11):3437-43.

157. Porter S, Scott SD, Sassoon EM, Williams MR, Jones JL, Girling AC, et al. Dysregulated Expression of Adamalysin-Thrombospondin Genes in Human Breast Carcinoma. Clinical Cancer Research. 2004 April 1, 2004;10(7):2429-40.

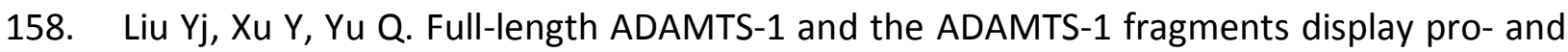
antimetastatic activity, respectively. Oncogene. 2005;25(17):2452-67.

159. Huang S, Ingber DE. The structural and mechanical complexity of cell-growth control. Nat Cell Biol. 1999;1(5):E131-E8.

160. Paszek MJ. Tensional homeostasis and the malignant phenotype. Cancer Cell. 2005;8:241-54.

161. Wozniak MA, Desai R, Solski PA, Der CJ, Keely PJ. ROCK-generated contractility regulates breast epithelial cell differentiation in response to the physical properties of a threedimensional collagen matrix. J Cell Biol 2003;163(3):583-95. 


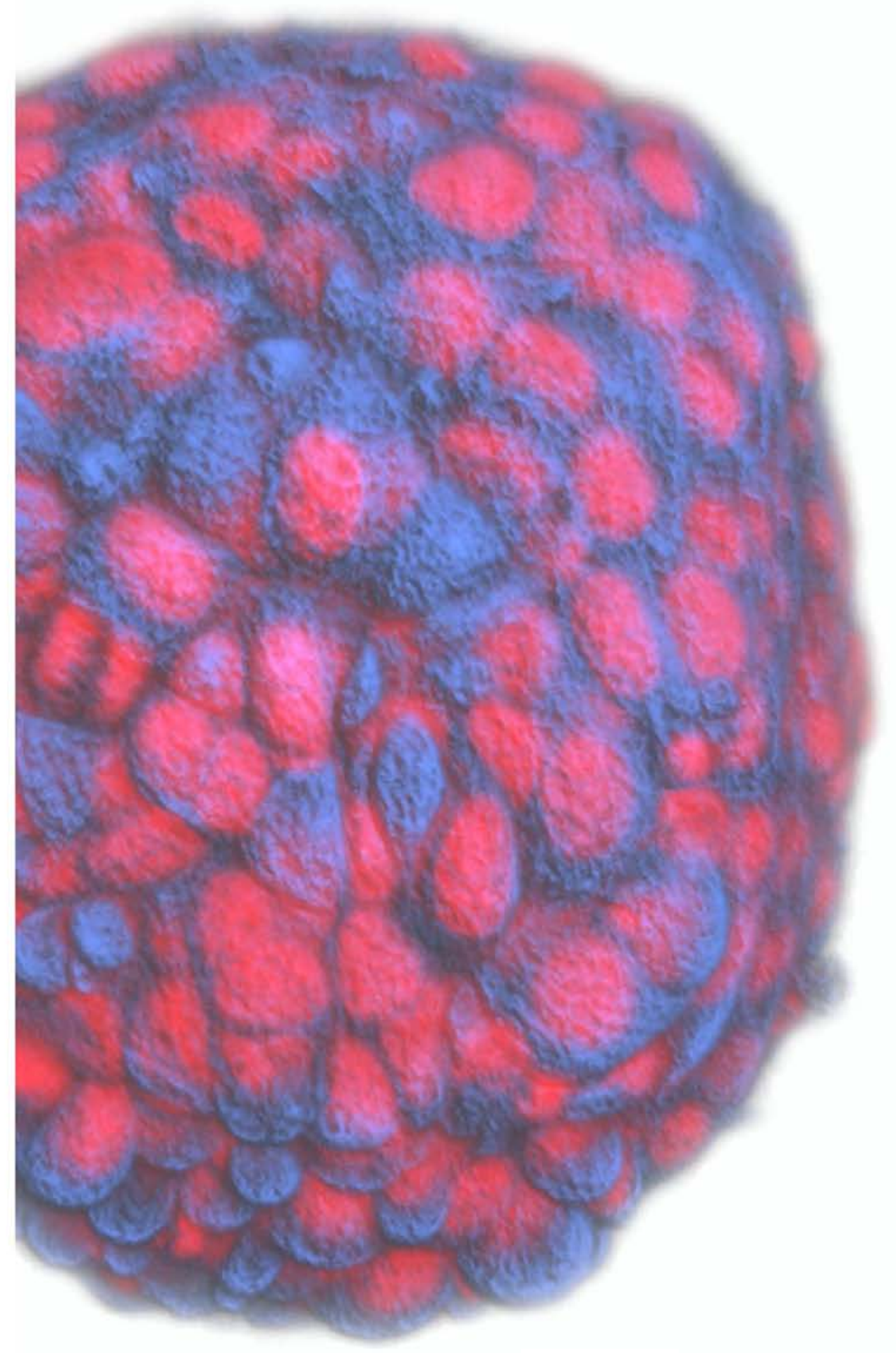

ANEXOS 
ANEXO A - ANIMAÇÕES

\section{LEGENDAS}

Todas as animações descritas abaixo se encontram gravadas em um DVD anexado ao final desta tese.
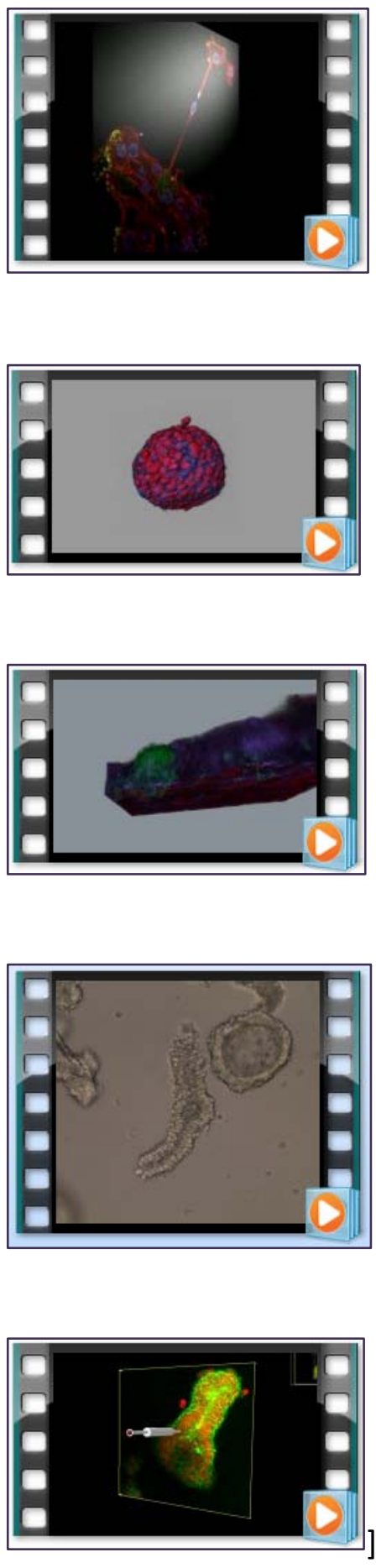

Animação 1-Reconstruções obtidas a partir de secções ópticas (microscópio confocal de varredura a laser), mostrando a formação do lúmen em esferóides de células MCF-7.

Animação 2-Reconstruções obtidas a partir de secções ópticas (microscópio confocal de varredura a laser), mostrando a organização das células quando arranjadas em esferóides com 7 dias de cultura 3D. Animação obtida utilizando o software Imaris 7.1

Animação 3-Reconstruções obtidas a partir de secções ópticas (microscópio confocal de varredura a laser), mostrando imunomarcação (em verde) para p-Akt em células crescidas após 7 dias de cultura 3D. Animação obtida utilizando o software Imaris 7.1

Animação 4-Série de imagens obtidas ao microscópio de luz utilizando campo claro onde é possível observar esferóides diferenciados com 50 dias de cultura

Animação 5-Reconstruções obtidas a partir de secções ópticas (microscópio confocal de varredura a laser), mostrando o espaço luminal por dentro de esferóides diferenciados. Esferóides com 25 dias de cultura (linhagem selecionada para formar lúmen) 
ENCARTE COM DVD 
ANEXO B - ARTIGO PUBLICADO

do Amaral J, B, Shiniti Urabayashi M, Maria Machado-Santelli G. Cell death and lumen formation in spheroids of MCF-7 cells. Cell Biology International. 2010 Feb 1;34(3):267-74. 
Cell

Biology

International

\title{
Cell death and lumen formation in spheroids of MCF-7 cells
}

Jônatas Bussador do Amaral ${ }^{1}$, Marcel Shiniti Urabayashi and Gláucia Maria Machado-Santelli

Department of Cell and Developmental Biology, Institute of Biomedical Sciences, University of Sấo Paulo, Av. Lineu Prestes 1524, São Paulo 05508900, Brazil

\begin{abstract}
3D (three-dimensional) cell culture permits a more integrated analysis of the relationship between cells, inserting them into a structure more closely resembling the cellular microenvironment in vivo. The development of in vitro parameters to approximate in vivo 3D cellular environments makes a less reductionist interpretation of cell biology possible. For breast cells, in vitro 3D culture has proven to be an important tool for the analysis of luminal morphogenesis. A greater understanding of this process is necessary because alterations in the lumen arrangement are associated with carcinogenesis. Following lumen formation in 3D cell culture using laser scanning confocal microscopy, we observed alterations in the arrangement of cytoskeletal components ( $\mathrm{F}$-actin and microtubules) and increasing levels of cell death associated with lumen formation. The formation of a polarized monolayer facing the lumen was characterized through 3D reconstructions and the use of TEM (transmission electron microscopy), and this process was found to occur through the gradual clearing of cells from the medullary region of the spheroids. This process was associated with different types of cell death, such as apoptosis, autophagy and entosis. The present study showed that changes in the extracellular matrix associated with long periods of time in 3D cell culture lead to the formation of a lumen in MCF-7 cell spheroids and that features of differentiation such as lumen and budding formation occur after long periods in 3D culture, even in the absence of exogenous extracellular compounds.
\end{abstract}

Keywords: cell death; cytoskeleton; lumen formation; mammary adenocarcinoma; three-dimensional cell culture

\section{Introduction}

When we consider cancer to be a product of the interaction between different cell types with their microenvironment (Bissell and Radisky, 2001), the development of in vitro experimental models that more faithfully reproduce the 3D (three-dimensional) nature of physiological cellular interactions becomes necessary to study the multiple factors associated with tumour initiation and progression. The ability to create both cell-to-cell and cell-to-matrix interactions (Pampaloni et al., 2007) makes 3D cell culture an attractive model to replicate the peculiarities of the tumour microenvironment in vivo (Feder-Mengus et al., 2008). Normal breast cells grown in a monolayer normally lose their polarity, while in $3 \mathrm{D}$ cell culture, the glandular architecture is re-established and maintained, thus maintaining cell polarity. This situation is important for the regulation of cell growth, survival and maintenance of their differentiated state. Contrary to what is found in cells grown in a monolayer, 3D cell cultures associated with extracellular matrix elements show a cellular organization similar to that found in vivo. With cells grown in 3D culture models, the multicellular tumour spheroids (spheroids) have a well-organized spherical symmetry, with different cell populations arranged concentrically (MuellerKlieser, 2000; Friedrich et al. 2007). Topics studied in this model of breast carcinoma include analysis of the alterations of the activation of HER2 in the 3D environment (Pickl and Ries, 2009), the effect of marine compounds on the cytoskeleton (Freitas et al., 2008), the role of the stroma in carcinogenesis (Weigelt and Bissell, 2008), drug screening (Friedrich et al. 2009), angiogenic factors/polarity
(Chen et al., 2009) and morphogenesis (Yamada and Cukieman, 2007; Mailleux et al., 2008). In the present study, we monitored luminal morphogenesis by taking advantage of the integrative vision provided by this model. Analyses of the baso-apical polarity, tensegrity, cell death and interaction of spheroids with the extracellular matrix (Hebner et al., 2008; Ingber, 2008) provide a less reductionist model of tumour complexity, contributing important information about the roles of these processes in the development of breast cancer.

The objective of the present study was to evaluate cellular differentiation during luminal morphogenesis of cells derived from breast adenocarcinoma (MCF-7) when grown in a 3D cell culture.

\section{Materials and methods}

\subsection{Cell culture}

The cancer cell line MCF-7 (Soule et al., 1973) was obtained from the American Type Culture Collection and cultured in DMEM (Dulbecco's modified Eagle's medium) Ham's F12 (Gibco-BRL) supplemented with $10 \%$ FBS (fetal bovine serum) (Gibco-BRL). Cells were maintained as a monolayer at $37^{\circ} \mathrm{C}$ with $5 \% \mathrm{CO}_{2}$.

\subsection{Spheroid formation}

After treatment with $0.05 \%$ trypsin (Sigma-Aldrich), $10^{6}$ cells were seeded in non-adherent 90-mm-diameter Petri dishes (VWR) with

${ }^{1}$ To whom correspondence should be addressed (email amaraljb@gmail.com). Abbreviations: 3D, three-dimensional; BrdU, 5-bromo-2-deoxyuridine; PBSA, PBS without $\mathrm{Ca}^{2+}$ and $\mathrm{Mg}^{2+}$; Pl, propidium iodidie; SEM, scanning electron microscopy; TEM, transmission electron microscopy. 
$10 \mathrm{ml}$ of cell culture medium. The method used to induce spheroid formation was the anchorage-independent growth protocol described by Pickl and Ries (2009), with modifications. Neither scaffolds nor exogenous cell matrix components were added to the culture. The cell aggregates developed spontaneously, and spheroids were maintained in culture up to 155 days. The ages of the cultures in each kind of experiment are indicated in the Results section. The cell culture was maintained under the same conditions as the monolayer, and the culture medium was changed every 4 days.

\subsection{Electron microscopy}

The spheroids were fixed for $2 \mathrm{~h}$ with $2.5 \%$ glutaraldehyde and $2 \%$ formaldehyde in $0.1 \mathrm{M}$ sodium cacodylate buffer $(\mathrm{pH} 7.2)$ for SEM (scanning electron microscopy) and TEM (transmission electron microscopy). Fixed samples were washed in $0.1 \mathrm{M}$ sodium cacodylate buffer $(\mathrm{pH} 7.2)$ and postfixed in $1 \%$ osmium tetroxide in the same buffer. The spheroids were dehydrated in a graded ethanol series and propylene oxide. The resin infiltration was performed with a 1:1 mixture of propylene oxide and epon for $5 \mathrm{~h}$, followed by $100 \%$ epon for another $5 \mathrm{~h}$. Next, the material was embedded, followed by $48 \mathrm{~h}$ of polymerization. Thin sections were produced using an ultramicrotome, and these were stained with Toluidine Blue. The spheroids were then thin-sectioned at $70-90 \mathrm{~nm}$ and stained with 4\% uranyl acetate and $10 \%$ lead citrate solution. The material was analysed with a Jeol 1010 transmission electron microscope $(80 \mathrm{kV})$. For SEM, the spheroids were washed in buffer and dehydrated with a graded ethanol series, followed by drying with hexamethyldisilazane. The material was coated by gold sputtering for $140 \mathrm{~s}$ and viewed with a Jeol 6100 scanning electron microscope (30 kV).

\subsection{Immunofluorescence and $3 \mathrm{D}$ analyses}

The cells were fixed with a $3.7 \%$ formaldehyde solution, permeated with $0.1 \%$ Triton $\mathrm{X}-100$ for $20 \mathrm{~min}$ and treated with RNAase $(10 \mathrm{mg} / \mathrm{ml})$ for $30 \mathrm{~min}$. The spheroids were then incubated overnight with monoclonal antibodies against $\alpha$ - and $\beta$-tubulin $(1: 100)$ or anti-laminin $(1: 100)$ inside a wet chamber. After three washes with PBSA (PBS without $\mathrm{Ca}^{2+}$ and $\mathrm{Mg}^{2+}$ ), preparations were incubated for $1 \mathrm{~h}$ with anti-mouse CY5 (Molecular Probes) (1:100). The spheroids were stained with phalloidin-FITC (SigmaAldrich) $(7.5 \mu \mathrm{M})$ for $40 \mathrm{~min}$. The preparations were washed in PBSA at every step of each reaction. The nuclei were counterstained using $5 \mu \mathrm{l}$ of $\mathrm{PI}$ (propidium iodide) $(10 \mu \mathrm{l} / \mathrm{ml})$. The cytological preparations were mounted between the slide and coverslip with anti-fading solution (Vectashield, Vector) and observed under a laser scanning confocal microscope (Zeiss LSM 510). Fluorescent images were obtained using argon (at 458, 488 and $514 \mathrm{~nm}$ ), Helium-Neon1 (at $543 \mathrm{~nm}$ ) and Helium-Neon2 (at $633 \mathrm{~nm}$ ) lasers. Optical sections were obtained for the appropriate sectioning ranges of the $z$-axis between 0.3 and $0.7 \mu \mathrm{m}$. Different modules from the LSM 510 3D software (Carl Zeiss) were used in the confocal analyses, including slice projections, orthogonal sections and animations.

\subsection{BrdU (5-bromo-2-deoxyuridine) incorporation}

Spheroids were grown in nomal culture medium and, for S-phase identification, BrdU (5-bromo-2-deoxyuridine; $50 \mu \mathrm{M}$ ) was added to cultures for $3 \mathrm{~h}$. After fixation with a solution of ethanol and acetic acid $(3: 1, v / v)$ for $30 \mathrm{~min}$, the cells were permeated with $0.1 \%$ Triton $\mathrm{X}-100$ for $20 \mathrm{~min}$. The DNA of the spheroids was denatured by incubation in $2 \mathrm{M} \mathrm{HCl}$ for $30 \mathrm{~min}$. The cells were then rinsed three times with PBSA and incubated with a primary mouse anti-BrdU antibody (1:100) for $2 \mathrm{~h}$. The spheroids were washed with PBSA and incubated with a secondary antibody, anti-mouse CY5 (1:100), for $1 \mathrm{~h}$.

\subsection{Cell death detection}

Apoptosis was assessed with the M30 CytoDEATH fluoresceinconjugated antibody (mouse monoclonal, clone M30, Roche Applied Science) diluted 1:250 and incubated for $2 \mathrm{~h}$ at room temperature (approx. $25^{\circ} \mathrm{C}$ ) (Freitas et al., 2008). This antibody recognizes caspase-cleaved cytokeratin 18. The M30 antibody was used to monitor caspase-3 activation (Leers et al., 1999). Autophagy and entosis were identified according to the morphological criteria established by Levine and Yuan (2005) and Overholtzer et al. (2007). The criteria described by Kroemer et al. (2009) were used for the classification of the types of cell death.

\section{Results}

From the first days of 3D cell culture, the MCF-7 cells aggregated and formed spheroids (Figure 1A). Inverted phase-contrast microscopy showed that the spheroid growth and the development of a dark area in the central region, termed the cell death region (Figure 1B), occurred simultaneously.

On approximately the 20th day of culture, there were many mitotic cells showing a greater degree of cortical cell proliferation. This observation was also confirmed through the examination of BrdU incorporation (Figure 6), showing the presence of S-phase cells in these spheroids. Regionalized cortical buds that formed (Figure 1B) had a tendency to lengthen in the spheroids over the course of the culture and formed a luminal arrangement very similar to that seen in breast glands (Figure 1C, 75 days). Interestingly, we were able to maintain the $3 \mathrm{D}$ cultures for up to 155 days, by which time they had reached a diameter of approx. $500 \mu \mathrm{m}$. It was difficult to determine the final size of the spheroids as they continued to elongate throughout the culture period. Mitotic cells were also observed in these structures; however, it seems that the cell population achieved a balanced size.

The external surface of the spheroids was analysed using SEM (Figures 1D and 1D1), and the MCF-7 cells appeared highly juxtaposed with cell plasma membrane projections on the external spheroid surface. This pattern was maintained throughout the 3D cell culture period, and components of the cell matrix were not observed on the surface of the examined spheroids (Figure 1D1).

Hypothesizing that alterations in the morphology of the spheroids were accompanied by cytoskeletal rearrangement, we 

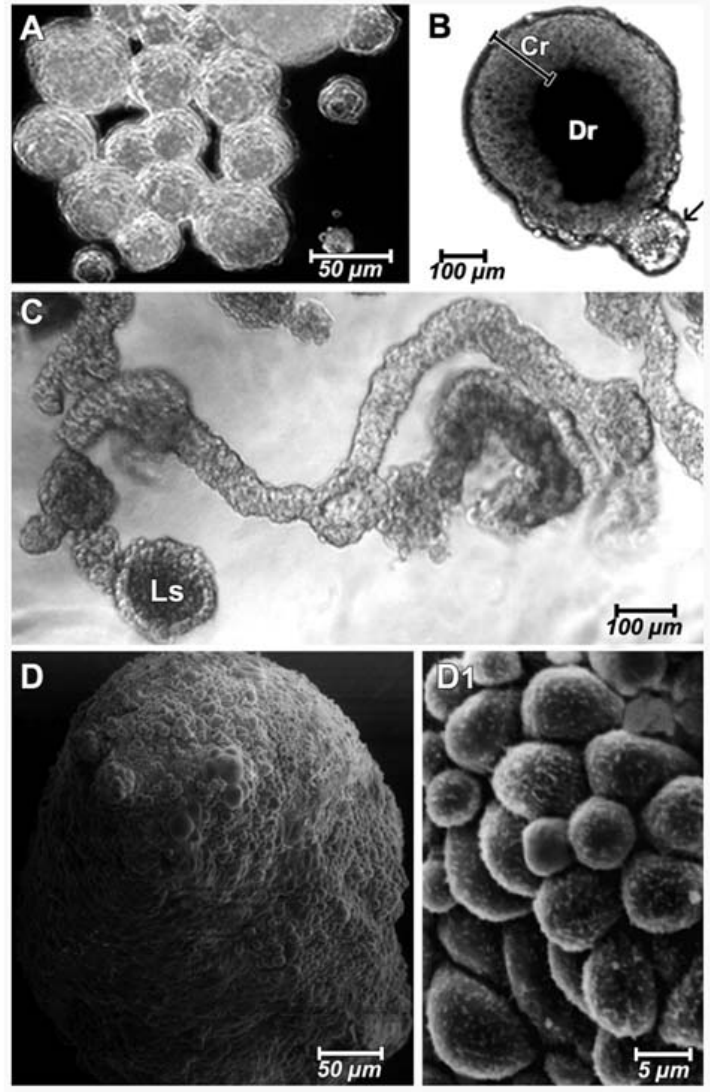

Figure 1 External and internal morphology alterations of spheroids in MCF-7 cells

The spherical morphology (A, 3 days) changed with cell budding (arrow) and increased size of the cell death region (Dr) (B, 20 days). At longer culture times, spheroids showed an elongated arrangement with lumen (Ls) (c, 75 days). Extemally, SEM showed cell membrane projections of MCF-7 cells with little extracellular matrix (D and D1, 30 dayss. Cr, cortical region. Figures (A), (B) and (C) are images from inverted phase-contrast microscopy.

looked for possible modifications of the actin filament and microtubule structures going from the monolayer (Figure 2A) to the formation of spheroids with a large luminal space (Figures 2G2l). Immunofluorescence staining with anti- $\alpha$-tubulin and anti- $\beta$ tubulin antibodies showed a typical arrangement of these components, mainly in the process of cell division (Figure 2A1). During the key stages of lumen formation, such as the fomation of spheroids (Figure 2B), cortical budding (Figures $2 \mathrm{C}$ and 201), elongation of the spheroids (Figures $2 \mathrm{E}$ and $2 \mathrm{~F}$ ) and formation of the adluminal monolayer (Figure 2l), the general microtubule arrangement did not change. The actin microfilaments became more concentrated in the apical region of MCF-7 cells in contact with the lumen. This characteristic occured from the beginning of the fomation of the luminal space (spheroid elongation) and was more prominent after the formation of the adluminal monolayer (Figures 2D, 2G and 2H). Observations using a laser scanning confocal microscope also made it possible to observe changes in nuclear morphology, mainly in the central region of the spheroids.

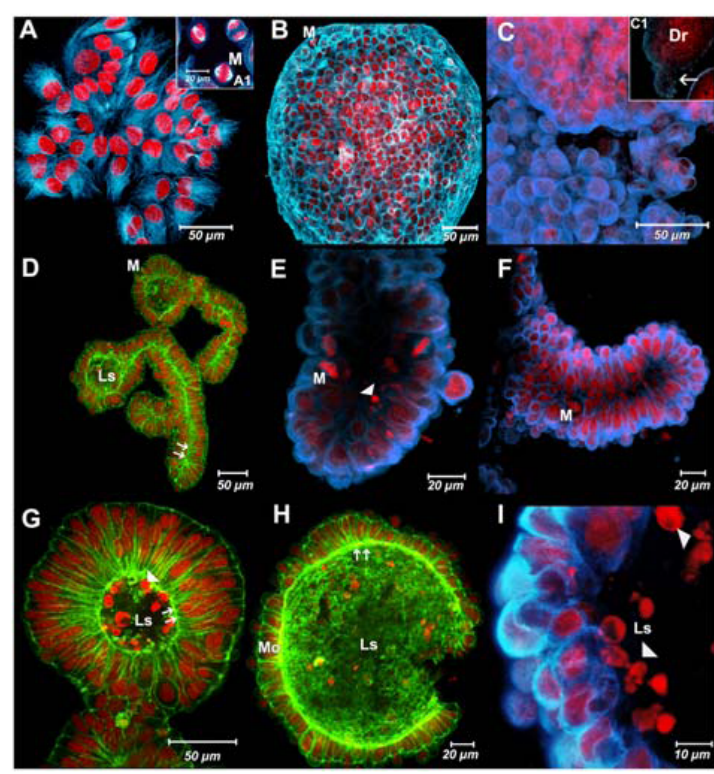

Figure 2 Cytoskeleton and lumen formation in MCF-7 spheroids

Laser scanning confocal microscope images are shown: monolayer of MCF-7 Cells (A) until the formation of the cysts with luminal space $(\mathbf{H})$. Microfilaments of actin (green) $(\mathbf{D}, \mathbf{F}, \mathbf{G}$ and $\mathbf{H})$ are concentrated (double arrow) on the inner surface of the lumen $(\mathbf{D}, \mathbf{G}$ and $\mathbf{H}$ ). The microtubules ( $\alpha$ - and $\beta$-tubulin anti-CY5 in blue) are uniformly arranged at the monolayer stage (A), 10 days of culture (B), 35 days of culture (C and C1) 75 days of culture ( $E$ and $l$ ) and 155 days of culture ( $F$ ). Inside the luminal space (LS) there was nuclear fragmentation (head of arrow in $\mathbf{G}, \mathbf{E}$ and $\mathbf{l}$ ). M, mitosis; Mo, adluminal monolayer, Dr, cell death region. (C1) Arrow shows detail of (C).

An increasing number of picnotic nuclei in the cell death region in the spheroids after 35 days in culture (Figure 20) was slowly substituted with a luminal space containing nuclear fragments in its interior, indicating apoptosis (Figures 2D-2E and 2G-2l). This observation was also confimed with reactivity to the M30 antibody (detecting cleaved cytokeratin 18) (Figure 6).

The process of lumen fomation was analysed using TEM, focusing on cell differentiation in the cortical region and the progressive process of cell death in the medullary region.

In the initial stages of the 3D cell culture, the presence of mitosis and euchromatic nuclei indicated an increase in cellular activity (Figure $3 \mathrm{~A}$ ). Despite the strong aggregation of cells, the formation of cell junction components was rarely observed (Figures $3 \mathrm{~A}$ and $3 \mathrm{~A} 1$ at 10 days). The increase in diameter of the medullary region was associated with a greater number of autolysosomes, different nuclear condensation stages and apoptotic cells (Figures 3B and 3B1 at 30 days). On approximately the 60 th day of cell culture, the adluminal monolayer was formed by columnar cells, superimposed and polarized. In this differentiation phase of the spheroids, the cellular junctions were already wellestablished (Figure 30), and these junctions (especially the desmosomes) were associated with bundles of tonofilaments. The luminal space formed was delimited by single layer of cells, and the apical region of these cells was facing this lumen (Figures 301 and 3C3). When observed at high magnification (Figures 3C2a and $3 \mathrm{C} 4$ ), the apical cell region was found to have 


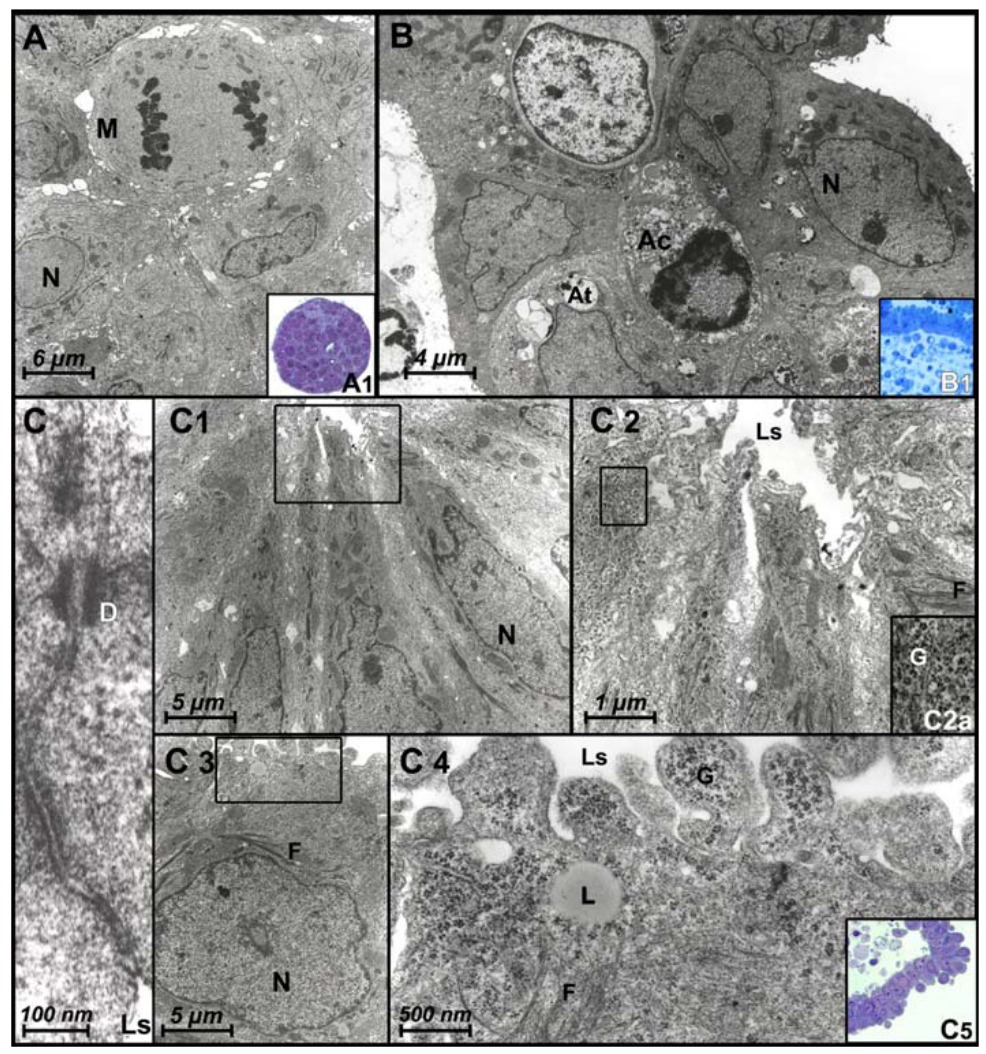

Figure 3 TEM analysis of cell morphology and differentiation in MCF-7 cells

Extended 3 D culture resulted in a decrease in the number of MCF- 7 cells in the luminal space and polanization of cells located in the cortical region of spheroid (compare 5 days, 30 days and 75 days in A, B and C1). Cells adopted a columnar-like form and developed some polarized desmosomes (D and C). Electron-dense material in the apical region (G) near the luminal space (LS) (detail in C2, G2a and CA). Panels A1, B1 and $\mathbf{C 5}$ show thin slices stained with Toluidine Blue, which allows an overview of the material analysed. N, nucleus; L, lipid; As, apoptotic cells; At, autolysosomes; $F$, intemediate filaments; M, mitosis.

vesicles with granular, electron-dense material, as well as associated lipids and intermediary filaments (Figure 3C4). Different cell death processes occurred mainly in the medullary region (Figures $4 \mathrm{~A}-4 \mathrm{E}$ ). As many cell death processes other than necrosis were observed, we suggest that the 'cell death region' is a more appropriate term than the 'necrotic nucleus'. In the spheroids, the gradual cellular clearance in this region was observed to occur as the result of different processes such as apoptosis (Figure 4B), death by autophagy (Figure 4D) and entosis (Figure 4E). In spheroids that had been cultured for longer times (more than 60 days), the lumen created as a result of this cellular clearance maintained some cells in the interior during the cell death processes (Figure 4D1). The apoptotic cells presented a greater electron density compared with adjacent cells (Figures 4A and $4 \mathrm{~B}$ ), showing gradual nuclear compaction and posterior cell fragmentation through plasma membrane blebs. At the region of cell death, many cells presented a very active vesicular-lysosomal complex (Figure 4A), and it was also possible to observe many autophagic vesicles and autolysosomes (Figure 4C). Cells also died through autophagy, presenting nuclear compaction, a large number of autolysosomes and later rupture of the plasma membrane of cell (Figure 4D). Some cells in the process of autophagy were interiorized through entosis (Figures $4 \mathrm{E}$ and $4 \mathrm{E} 1$ ). The process of entosis was observed both in the cell death region (Figures $4 \mathrm{E}$ and $4 \mathrm{E} 1$ ) and the cortical region (Figures $4 \mathrm{~F}$ and $4 \mathrm{~F} 1$ ). During the entosis process, the phagocytic cells contained euchromatic nuclei and a well-developed and wrinkled endoplasmic reticulum (see cell $\mathrm{C} 1$ in Figure 4F). Cells in the process of necrosis were also processed through entosis (Figure 4F).

\section{Discussion}

The intrinsic complexity of the luminal morphogenesis in breast tissue derives from an intimate interaction between the epithelial 


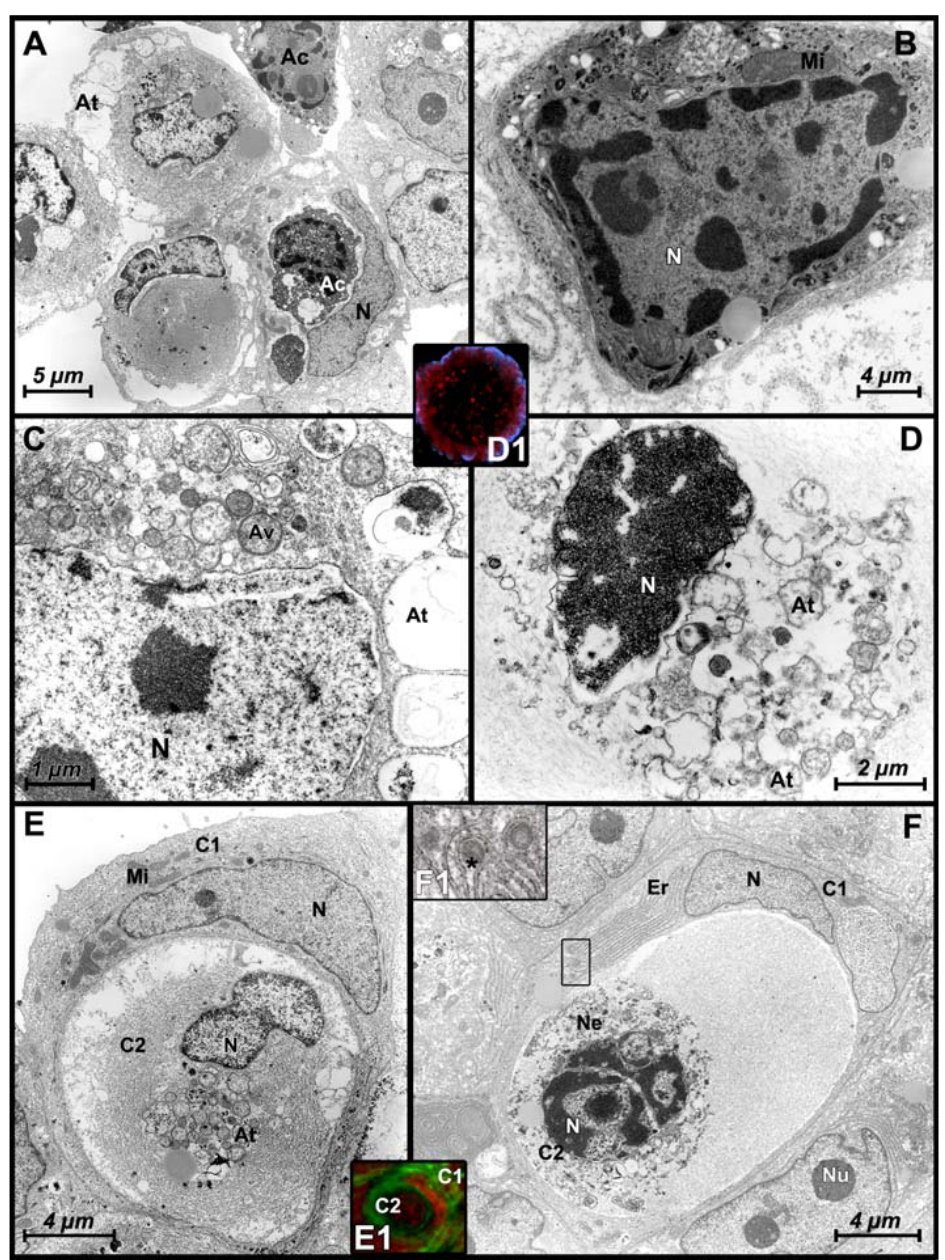

Figure 4 Cell death in MCF-7 cell spheroids

Ovenview of the cell death region, showing some cells in the process of apoptosis (AC in A). Apoptotic cell (B). Cell with autophagic vacuoles (Av) and autolysosomes (At) (C). Autophagic cell death (D). Cells in the process of entosis in cell death region-Cell (C2) with a large number of autolysosomes (At) is internalized by another cell (C1) (E). Entosis in the cortical region showing a cell in the process of necrosis (Ne-C2) being internalized (C1) (F). Detail of (F) shrowing vesicles (") next to the rough endoplasmic reticulum (F1). (D1) Microtubules/blue and nuclei/red and (E1) F-actin shown in green and nuclei in red $B$ and $E$ ) Sphervids after 25 days of culture. (C, D and F) Sphervids after 155 days of culture.

cells and their microenvironment. The reproduction and analysis of this process in vitro are a challenge because different regulatory pathways participate in lumen fomation. The re-establishment of non-tumoral characteristics in the MCF-7 lineage in 3D cell culture suggested the possibility of reversal of some pathways, which resulted in morphological alterations. The absence of a lumen is a characteristic of spheroids originating from breast adenocarcinomas. This peculiarity was used by Kenny et al. (2007), who described the morphology of spheroids originating from different breast cell lineages and divided them into four groups: round, mass, grape-like and stellate. The spheroids of the MCF-7 lineage were classified as a mass of cells, with disorganized nuclei, strong cell-to-cell bonds and an absence of lumen formation. Similar characteristics to the ones described by those authors were observed in the initial phases of the present study. However, the gradual cell clearance in the cell death region in these spheroids culminated in a polarized cortical monolayer (see Supplementary movie at $\mathrm{http} / / \mathrm{ww} w$.cellbiolint.org/cbi/034/cbi0340267add.htm), 


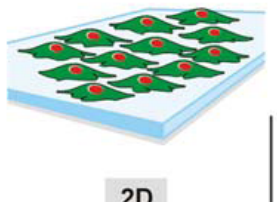

2D

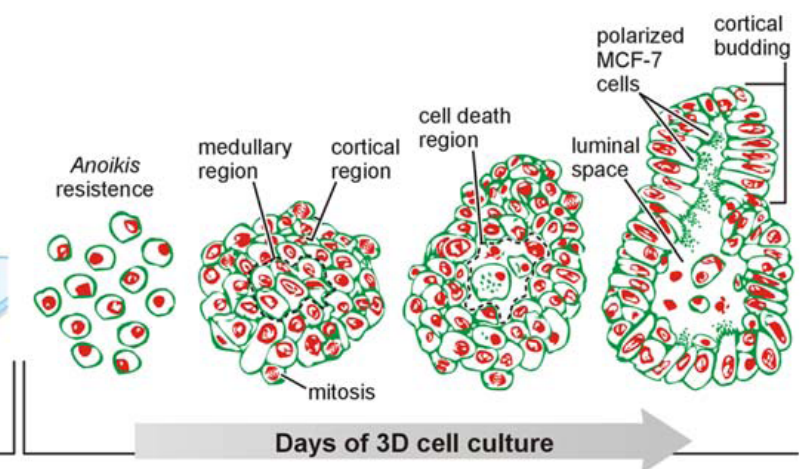

Days of 3D cell culture

Figure 5 Illustration of lumen formation in MCF-7 cell spheroids

which would put the lineage in the round classification. Kirshner et al. (2003) were able to establish cellular polarization in spheroids of MCF-7 cells, modulating cell-to-cell adhesion molecules and showing the role of CEACAM1-4S (carcinoembryonic antigenrelated cell adhesion molecule 1) and the role of apoptosis in lumen formation.

The necrotic core in the central region of the multicellular tumour spheroids has been compared with avascular metastases. The necrotic process that has long been associated with hypoxia (Acker et al., 1984; Bjerkvig, 1992) did not present itself as a critical factor in the formation of the lumen, as shown by the remarkable presence of apoptosis and cell death by autophagy. Through ultrastructural analysis, cells in the necrotic stage were identified in all the spheroids, including within the lumen. The single layer of cells surrounding this central core reduces the chances that these necrotic cells are experiencing hypoxia. Degenhardt et al. (2006) discuss the necrosis signalling pathways, suggesting that this process could possibly be a result of the combined impairment of apoptosis and autophagy.

The dynamic balance between cell proliferation and cell death is responsible for the formation of the lumen in MCF-7 spheroids. This begins with the selection of cells resistant to the anoikis process (Simpson et al., 2008) in which cells are grouped form spheroids (Figure 5). The growth of spheroids is the result of this aggregation and cell proliferation (Figure 6).

Cell death by apoptosis was present in all regions of the spheroid, but was more frequent in the cell death region (central region). Debnath et al. (2002) described the role of apoptosis in maintaining the glandular architecture in spheroids of the breast lineage MCF-10A, showing that lumen formation was associated with selective apoptosis in the central region. When apoptosis was blocked, the lumen formation continued, suggesting that another regulatory pathway participated in lumen formation. Mills et al. (2004), using a similar model, suggested that the cavities in MCF-10A spheroids would be a consequence of cellular elimination by autophagy and apoptosis, two distinct pathways that complemented each another. This complementary effect was also observed in the present study; however, there was participation of another non-apoptotic cell-death pathway in the clearing of cells for lumen fomation: entosis. Entosis involves the invasion of
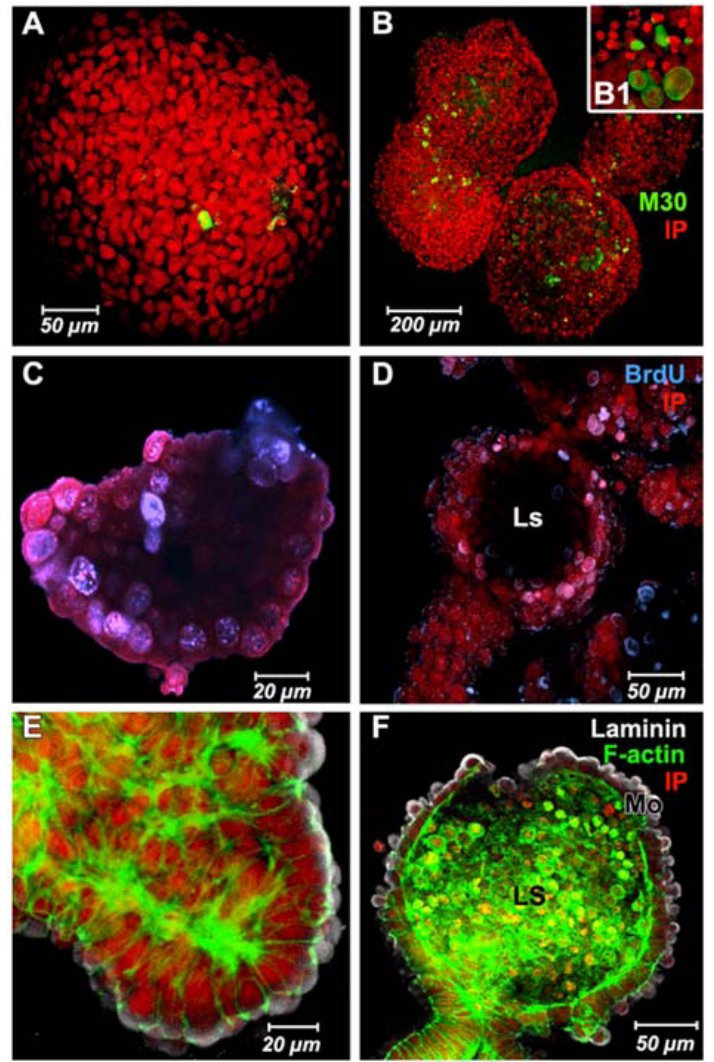

Figure 6 Immunolabelling for laminin, proliferation and cell death in the MCF-7 spheroids

Images were obtained by laser scanning confocal microscopy. (A and B) Lower level o M30 (anti-M30/FITC, green) in sphervids after 10 days of culture (A) compared witt 115 days of culture (B). The incorporation of BrdU (anti-BrdU/CY5, blue) shower greater cell proliferation in spheroids after 7 days of culture (C) than after 60 days 0 culture (D). In sphervids with a developed luminal space (LS) (75 days) the extema monolayer (Mlo) expressed laminin (anti-laminin/CY5, white). The nuclear morpholog was analysed using PI. (E and $\mathrm{F}$ ) Labelled F-actin microfilaments stained witt phalloidin-FITC (green). (B1) shows detail of the central region of (B). 
one live cell by another cell, followed by the degradation of the intemalized cell by lysosomal enzymes (Overholtzer et al., 2007). The occurrence of entosis, as has been described in tumours and cell lineages (including MCF-7 in suspension), is associated with cell populations deprived of attachment to the extracellular matrix.

When grown in a 3D environment, the MCF-7 cells present apoptotic and autophagic cells during lumen formation, but cells in the process of entosis were also found in the cortical region of the spheroid. This fact suggests that cell-to-cell contacts can regulate this process, permitting the occurrence of entosis in different regions of the spheroid, not only within the lumen. These results show that the lumen formation occurs in a regulated manner in the cell death region, not as a result of necrosis. Resistance to anoikis, apoptosis, entosis and autophagic cell death that occur in the medullary region resulted in the establishment of a cell monolayer. This region presented a greater concentration of microfilaments in the apical region (a characteristic of microvilli, according to Hogan and Kolodziej, 2002) and delivered secretion products to the region facing the lumen (Figure 5).

The regulation of the tension mediated by the cytoskeleton components dynamically interacts with factors extemal to the cell. Therefore, an environment that allows for cell growth in different planes per se can already be considered a stimulus that permits consequent morphological alterations. When analysing the formation of MCF-7 cell spheroids with a lumen (cystic arrangement), the presence of regionalized cortical buds was observed. The development of this characteristic associated with the formation of lumen in these buds shows that this method of culture, with increased culture time and the absence of exogenous extracellular compounds, can be used for the study of tubulogenesis. The formation of these structures was similar to the micromorphogenesis described by others (Huang and Ingber, 1999; Ingber, 2008), who related this to mechanical stress due to alterations of the extracellular matrix. When the endogenous and exogenous tension force increases are mediated by a prolonged hardness of the matrix, this can activate related mechanoregulatory pathways [ERK (extracellular-signal-regulated kinase) and Rho] and stabilize focal contacts (Paszek et al., 2005). Wozniak et al. (2003) suggest that, for breast cells in environments where the matrix is more flexible, ROCK (Rho kinase) down-regulates the activity of Rho, which leads to a sequence of events that result in the differentiation in tubules.

It has been shown that epithelial breast cell morphogenesis seems to be driven by laminin when $3 \mathrm{D}$ cultures are grown in reconstituted basement membranes derived from EngelorethHolm-Swarm tumour supplemented culture medium (Gudjonsson et al., 2002). This study shows that features of differentiation, such as lumen and bud formation, occur after long periods in 3D culture in the absence of exogenous extracellular compounds. Thus, if laminin is important in the induction of this differentiation process, this culture system would depend on its own synthesis of this protein.

\section{Author contribution}

Jonatas do Amaral established the spheroid culture conditions, carried out the electron microscopy and immunofluorescence experiment and drafted the manuscript. Marcel Urabayashi partipated in morphological analysis and conducted some immunofluorescence reactions. Gláucia Machado-Santelli designed the study, co-ordinated the experiments, participated in confocal imaging and analysis and wrote the final version of the manuscript. All authors read and approved the final manuscript.

\section{Acknowledgements}

We thank Roberto Cabado Modia Jr (for aid with the artwork and $3 D$ reconstructions) and Edson Rocha de Oliveira and Gaspar Ferreira de Lima (for electron microscopy support).

\section{Funding}

This work was supported by FAPESP (Fundacão de Amparoà Pesquisa do Estado de São Paulo) [process number 06/01026-0]; CNPq (Conselho Nacional de Desenvolvimento Cientifico e Tecnológico); Capes (Coordenacão de Aperfeiçoamento de Pessoal de Nivel Superior); and by the Secretaria da Educação do Estado de Sáo Paulo.

\section{References}

Acker $\mathrm{H}$, Carlsson J, Durand RE, Sutherland RM. Spheroids in cancer research. Springer-Verlag, Berlin, 1984

Bjerkvig R. Spheroid culture in cancer research. CRC Press, Boca Raton, FL, 1992.

Bissell MJ, Radisky D. Putting tumours in context. Nat. Rev. Cancer 2001:1:46-54.

Chen A, Cuevas I, Kenny PA, Miyake H, Mace K, Ghajar C et al. Endothelial cell migration and vascular endothelial growth factor expression are the result of loss of breast tissue polarity. Cance Res. 2009;69:6721-9.

Debnath J, Mills KR, Collins NL, Reginato MJ, Muthuswamy SK, Brugge $\mathrm{JS}$. The role of apoptosis in creating and maintaining luminal space within normal and oncogene-expressing mammary acini. Cell 2002;111:29-40.

Degenhardt K, Mathew R, Beaudoin B, Bray K, Anderson D, Chen G et al . Autophagy promotes tumor cell survival and restricts necrosis, inflammation, and tumorigenesis. Cancer Cell 2006;10:51-64.

Feder-Mengus C, Ghosh S, Reschner A, Martin I, Spagnoli GC. New dimensions in tumor immunology: what does 3D culture reveal? Trends Mol Med 2008;14:333-40.

Freitas VM, Rangel M, Bisson LF, Jaeger RG, Machado-Santelli GM. The

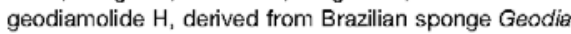
corticostylifera, regulates actin cytoskeleton, migration and invasion of breast cancer cells cultured in three-dimensiona environment. J Cell Physiol 2008;216:583-94

Friedrich J, Ebner R, Kunz-Schughart LA. Experimental anti-tumor therapy in 3-D: spheroids: old hat or new challenge? Int J Radiat Biol 2007:83:849-71.

Friedrich J, Seidel C, Ebner R, Kunz-Schughart LA. Spheroid-based drug screen: considerations and practical approach. Nat Protoc 2009;4:309-24.

Gudjonsson T, Ronnov-Jessen L, Villadsen R, Rank F, Bissell MJ, Petersen OW. Normal and tumor-derived myoepithelial cells differ in their ability to interact with luminal breast epithelial cells for polarity and basement membrane deposition. J Cell Sci 2002;115:39-50

Hebner C, Weaver VM, Debnath J. Modeling morphogenesis and oncogenesis in three-dimensional breast epithelial cultures. Annu Rev Pathol 2008;3:313-39. 
Hogan BL, Kolodziej PA. Organogenesis molecular mechanisms of tubulogenesis. Nat Rev Genet 2002;3:513-23.

Huang S, Ingber DE. The structural and mechanical complexity of cellgrowth control. Nat Cell Biol 1999;1:E131-8.

Ingber DE. Tensegrity-based mechanosensing from macro to micro. Prog Biophys Mol Biol 2008:97:163-79.

Kenny PA, Lee GY, Myers CA, Neve RM, Semeiks JR, Spellman PT et al The morphologies of breast cancer cell lines in three-dimensional assays correlate with their profiles of gene expression. Mol Oncol 2007;1:84-96.

Kirshner J, Chen GJ, Liu P. Huang J, Shively JE. CEACAM1-4S, a cellcell adhesion molecule, mediates apoptosis and reverts mammary carcinoma cells to a normal morphogenic phenotype in a $3 D$ culture. Proc Natl Acad Sci USA. 2003;100:521-6.

Kroemer G, Galluzzi L, Vandenabeele P, Abrams J, Alnemri ES, Baehrecke EH et al. Classification of cell death: recommendations of the Nomenclature Committee on Cell Death 2009. Cell Death Differ 2009:16:3-11

Lecrs MP, Kölgen W, Björklund V, Bergman T, Tribbick G, Persson B et al. Immunocytochemical detection and mapping of a cytokeratin 18 neo-epitope exposed during early apoptosis. J Patho $1999 ; 187: 567-72$.

Levine B, Yuan J. Autophagy in cell death: an innocent convict? J Clin Invest 2005:115:2679-88

Mailleux AA, Overholtzer M, Brugge JS. Lumen formation during mammary epithelial morphogenesis: insights from in vitro and in vivo models. Cell Cycle 2008;7:57-62.

Mills KR, Reginato M, Debnath J, Queenan B, Brugge JS. Tumo necrosis factor-related apoptosis-inducing ligand (TRAIL) is required for induction of autophagy during lumen formation in vitro. Proc Natl Acad Sci USA. 2004;101:3438-43.

Mueller-Klieser W. Tumor biology and experimental therapeutics. Crit Rev Oncol Hematol 2000;36:123-39

Overholtzer M, Mailleux AA, Mouneimne G, Normand G, Schnitt SJ, King RW et al. A Nonapoptotic cell death process, entosis, that occurs by cell-in-cell invasion. Cell 2007;131:966-79

Pampaloni F, Reynaud EG, Stelzer EK. The third dimension bridges the gap between cell culture and live tissue. Nat Rev Mol Cell Biol 2007:8:839-45

Paszek MJ, Zahir N, Johnson KR, Lakins JN, Rozenberg Gl, Gefen A et al. Tensional homeostasis and the malignant phenotype. Cancer Cell 2005;8:241-54

Pickl M, Ries $\mathrm{CH}$. Comparison of $3 \mathrm{D}$ and $2 \mathrm{D}$ tumor models reveals enhanced HER2 activation in 3D associated with an increase response to trastuzumab. Oncogene 2009;28:461-8.

Simpson CD, Anyiwe K, Schimmer AD. Anoikis resistance and tumor metastasis. Cancer Letters 2008;272:177-85.

Soule HD, Vazguez J, Long A, Albert S, Brennan M. A human cell line from a pleural effusion derived from a breast carcinoma. J Natl from a pleural effusion derived frer Inst 1973:51:1409-16.

Weigelt B, Bissell MJ. Unraveling the microenvironmental influences on the normal mammary gland and breast cancer. Semin Cancer Biol 2008:18:311-21.

Wozniak MA, Desai R, Solski PA, Der GJ, Keely PJ. RoCK-generated contractility regulates breast epithelial cell differentiation in response to the physical properties of a three-dimensional collagen matrix. J Cell Biol 2003:163:583-95.

Yamada KM, Cukierman E. Modeling tissue morphogenesis and cancer in 3D. Cell 2007;130:601-10.

Received 1 July 2009/26 August 2009; accepted 26 October 2009

Published as Immediate Publication 26 0ctober 2009, doi 10.1042/CBI20090024 


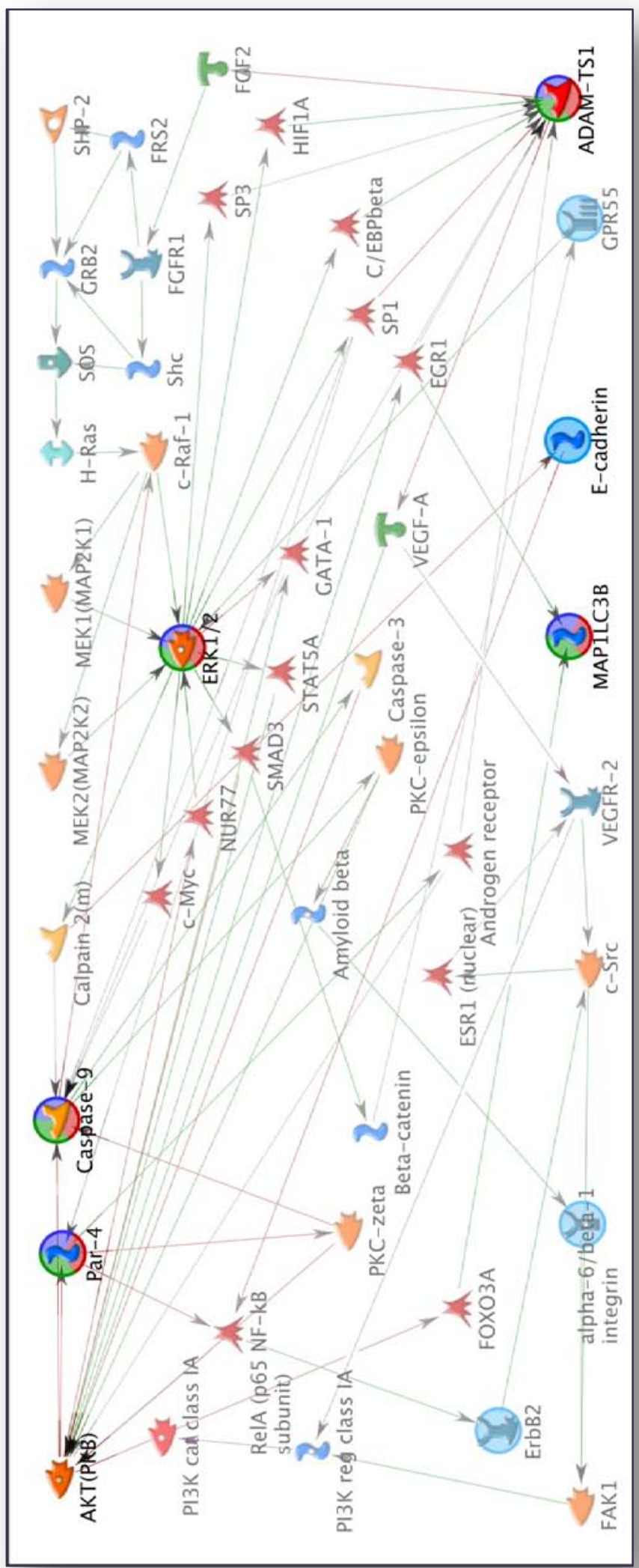

Figura 36 - Esquema mostrando vias de sinalização celular onde é possível observar as interações das proteínas analisadas neste presente trabalho. Esquema obtido utilizando o software Meta Core 